\title{
The upper Miocene Deurne Member of the Diest Formation revisited: unexpected results from the study of a large temporary outcrop near Antwerp International Airport, Belgium
}

STIJN GOOLAERTS ${ }^{1, *}$, JeF DE CEUSTER ${ }^{2}$, FREDERIK H. MOLLEN ${ }^{3}$, BERT GIJSEN $^{3}$, MARK BOSSELAERS ${ }^{1}$, OLIVIER LAMBERT ${ }^{1}$, ALFRED UCHMAN ${ }^{4}$, MiCHIEl VAN HERCK $^{5}$, RIEKO ADRIAENS ${ }^{6}$, RIK HOUTHUYS ${ }^{7}$, STEPHEN LOUWYE $^{8}$, YAANA BRUNEEL $^{5}$, JAN ELSEN $^{5}$ \& KRISTIAAN HOEDEMAKERS ${ }^{1}$

${ }^{1}$ OD Earth \& History of Life, Scientific Heritage Service and OD Natural Environment, Royal Belgian Institute of Natural Sciences, Belgium; stijn.goolaerts@naturalsciences.be; mark.bosselaers@telenet.be; olambert@naturalsciences.be;

kristiaan.hoedemakers@naturalsciences.be.

${ }^{2}$ Veldstraat 42, 2160 Wommelgem, Belgium; jefdeco@gmail.com.

${ }^{3}$ Elasmobranch Research Belgium, Rehaegenstraat 4, 2820 Bonheiden, Belgium; frederik.mollen@gmail.com; bert.gijsen@skynet.be.

${ }^{4}$ Faculty of Geography and Geology, Institute of Geological Sciences, Jagiellonian University, Gronostajowa 3a, 30-387 Kraków, Poland; alfred.uchman@uj.edu.pl.

5 Department of Earth \& Environmental Sciences, KU Leuven, Belgium; michiel.vanherck@student.kuleuven.be; yaana.bruneel@kuleuven.be; jan.elsen@kuleuven.be.

${ }_{7}^{6}$ Q Mineral, Heverlee, Belgium; radriaens@qmineral.com.

7 Independent consultant, Halle, Belgium; rik.houthuys@telenet.be.

${ }_{*}^{8}$ Department of Geology, Campus Sterre, S8, Krijgslaan 281, 9000 Gent, Belgium; stephen.louwye@ugent.be.

* corresponding author.

ABSTRACT. A $5.50 \mathrm{~m}$ thick interval of fossiliferous intensely bioturbated heterogenous glauconiferous sand of the upper Miocene Diest Formation is documented from a very large temporary outcrop just southeast of Antwerp International Airport (northern Belgium), allowing to observe lateral variations over several hundreds of meters and to collect many vertebrate and invertebrate fossils. This paper documents observations on lithology, sedimentary and post-sedimentary structures, and discusses the results of the multi-proxy analyses of the sediment (granulometry, glauconite content, clay mineralogy, $\mathrm{Fe}$ content and $\mathrm{Fe}^{3+} / \mathrm{Fe}^{2+}$ ratios), the interpretation of the trace fossil assemblage and the sedimentary structures as well as of the large-scale samplings of micro-, meso- and macrofossils. We evidence that the Diest Formation in the Antwerp area consists of two different lithological entities, and that this twofold character can be extrapolated to all previously recorded Deurne Member outcrops. A revised lithostratigraphic scheme for the Diest Formation in the Antwerp area is proposed, with the new Borsbeek member at the base and a redefined Deurne Member at the top.

KEYWORDS: Tortonian, glauconite, stratigraphy, fossils, Macaronichnus, 'Sables et grès à Hétérocètes', dinoflagellates, Dessel Sand Member.

\section{Introduction}

In the course of the last two centuries, the subsurface of the Antwerp area has received a lot of attention from geologists and paleontologists who were attracted by the large number of glauconiferous marine sediments yielding incredibly high numbers of well-preserved fossils that could be documented, sampled and studied whenever construction works reached into its shallowly buried Neogene deposits. Unfortunately, construction works are always temporary in nature, thus creating major pitfalls for the research on these deposits. In far too many cases, important outcrops remained undocumented or were only observed by a too limited number of researchers, hampering the advance of the understanding of the stratigraphy, sedimentology and paleontology of the Antwerp area Neogene.

Although the Miocene and Pliocene geology of the Antwerp area is relatively well documented, insights in the upper Miocene Deurne Member of the Diest Formation have largely been hampered by the low number of temporary outcrops reported in the literature, in particular since Glibert \& de Heinzelin de Braucourt (1955a, 1955b) summarized a century of observations on their 'Sables de Deurne'.

The current insights in the stratigraphy of the Antwerp area Neogene root for large parts in the works of four students of the KU Leuven Geology Lab in the late 60 s and early 70 s of the $20^{\text {th }}$ century: Frans De Meuter, Piet Laga, Adolf Ringelé and Karel Wouters. The stratigraphic framework published by De Meuter \& Laga (1976) still forms the base of the formal stratigraphy in use today. De Meuter \& Laga $(1970,1976)$ redefined the 'Sables de Deurne' to the Deurne Member, adhered it to the Diest Formation, and placed it low in the Diest Formation sequence as the sole stratigraphic unit that occurs in the Antwerp area.
The Deurne Member outcrops generally expose marginally thin sequences, ranging from 0.2 up to $1 \mathrm{~m}$ and exceptionally up to 2 or $3 \mathrm{~m}$, thus considerably thinner than the Diest Formation sequences of the Campine and Hageland areas, where sequences of more than $200 \mathrm{~m}$ are known (Houthuys et al., 2020). The by far thickest ever described interval attributed to the Deurne Member was exposed in an outcrop of $5.60 \mathrm{~m}$ and described by Bosselaers et al. (2004) from observations made at the construction site of a new wing of the Maria Middelares (Monica) Hospital in Deurne in 2001, where, unfortunately, only the topmost $2.60 \mathrm{~m}$ could be studied and sampled.

In 2014, a new temporary outcrop just south of Antwerp International Airport (AIA) located in the municipalities of Mortsel and Borsbeek (Antwerp Province, Belgium) exposed once more a thick Diest Formation sequence. This time, the entire $5.50 \mathrm{~m}$ thick interval of glauconiferous sand between the middle Miocene Berchem Formation and Pliocene shelly deposits could be studied in full detail across a length of several hundreds of meters in two elongated pits (LP1 and LP2, see Figs 1 \& 2) for the construction of a tunnel on the R11 road allowing the extension of the airport's runway. The current paper describes and discusses observations on lithology, sedimentary and pseudosedimentary structures, as well as the results of a multi-proxy analysis of the sediment (granulometry, glauconite content and characterization, clay mineralogy and Fe content and ferric/ferrous ratios), the extensive samplings of micro-, meso- and macrofossils, the identifications of the observed trace fossils and a dinoflagellate age dating.

\section{Material and methods}

This paper is for a large part based on field observations of three teams (De Ceuster Group (DCG), Elasmobranch Research 


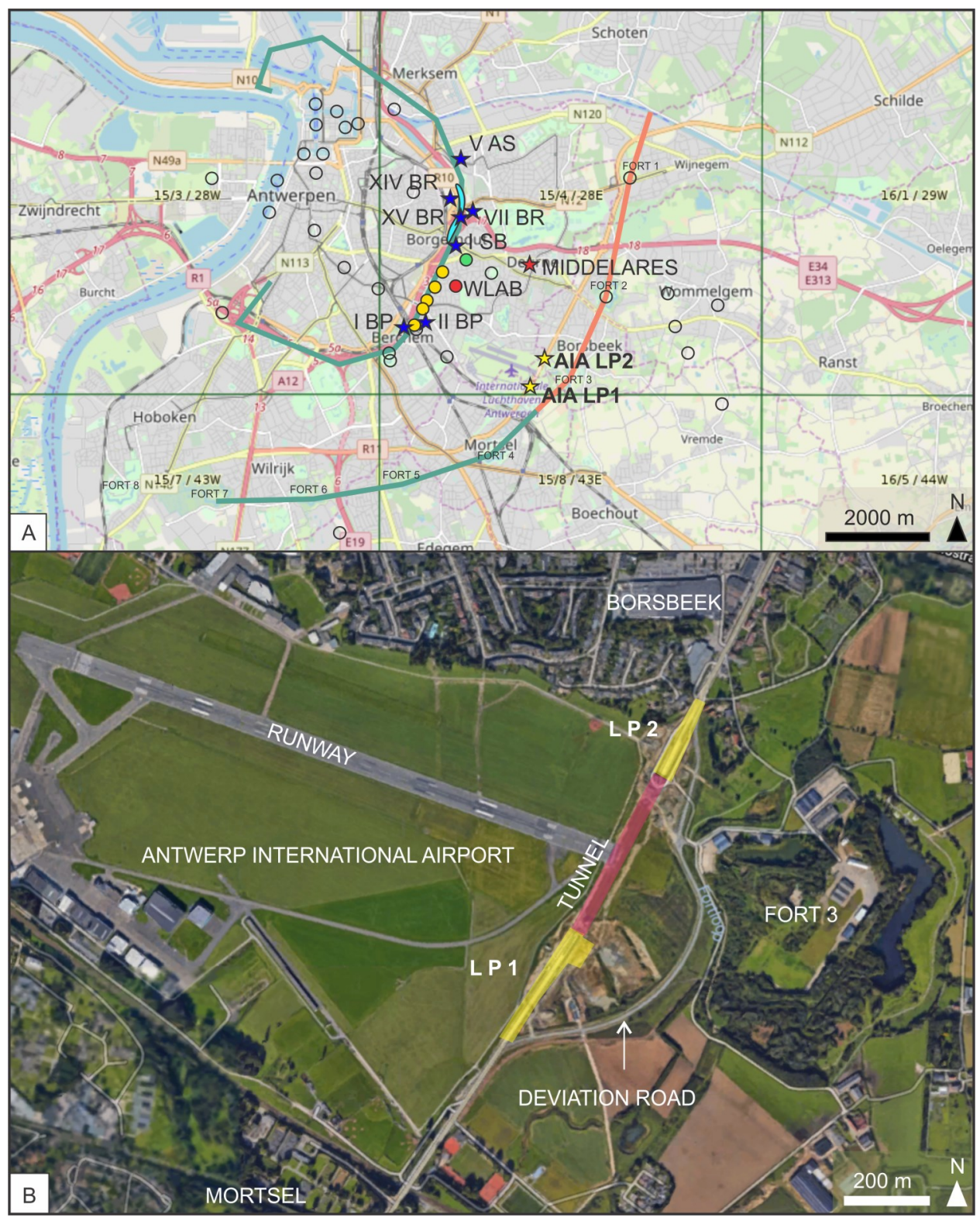

Figure 1. Geography of the study area. A. Map of the Antwerp area (modified from GISel) with the indication of the localities discussed in the text. Yellow stars: Antwerp International Airport (AIA LP1 \& LP2, this paper); red star: Middelares Hospital of Bosselaers et al. (2004); blue stars: temporary outcrops during construction of R1: Borsbeeksepoort (I BP \& II BP), Stenenbrug (I SB), Borgerhout Rivierenhof (VII BR, XIB BR) and Antwerpen Schijnpoort (V AS) of De Meuter et al. (1976), Borgerhout Foorplein (XV BR) of Ringelé (1974). Dots: localities listed by Glibert \& de Heinzelin de Braucourt (1955a); yellow dots: temporary exposures of 'Sables verts' described by Cogels (1874), Mourlon (1876) and Van den Broeck (1878), localities 37 and 4047 of Glibert \& de Heinzelin de Braucourt (1955a); green dot: Muggenberg sewer of Van Straelen (1920), locality 58 of Glibert \& de Heinzelin de Braucourt (1955a); red dot: Waterbouwkundig Labo (this paper), locality 38 of Glibert \& de Heinzelin de Braucourt (1955a); light blue patch: localities described by van den Bosch (1967a, 1967b, 1967c); green line: 'sables verts' in profiles of Dejardin (1862); orange line: 'sables gris' in profile of Dejardin. B. Google Maps Satellite view of the surroundings of the AIA site, with localization of the LP1 and LP2 pits and the tunnel segment in-between, in which for safety reasons, we were not allowed to enter.

Group Belgium (ERB) and Royal Belgian Institute of Natural Sciences (RBINS)) who intensively followed the progress of the AIA outcrop. Each group documented the stratigraphy of the outcrop and invested vast amounts of time in fossil collecting by either hand picking or by screen washing huge quantities of sediment (several thousands of 10-liter buckets throughout the section (DCG, RBINS) plus three big-bags of $1 \mathrm{~m}^{3}$ of layer $5 \mathrm{~b}$ and two bulk samples of $30 \mathrm{~m}^{3}$ of the basal part of layer $5 \mathrm{c}$ (ERB). Already at a very early stage of the outcrop, a first (unpublished) draft of the stratigraphy made by Jef De Ceuster, subdividing the section into several numbered layers, was distributed amongst the participants of DCG, allowing them to document their finds into a refined stratigraphic context. The same numbering of the layers is applied in this paper, however with a further subdivision of layer 5 into $5 \mathrm{a}, 5 \mathrm{~b}$ and $5 \mathrm{c}$, the additions of layers $9,4 \mathrm{~b}$ and $\mathrm{X}$, and a slightly different definition of layer 6 (Fig. 2).

While this paper focusses on stratigraphy, sedimentology and relative dating, and integrates and discusses some paleontological results of the fossil collecting, additional papers are in preparation zooming in on specific parts of the collected material. A preliminary description of the site and some of its fossil content (with special focus on chondrichthyan fishes) was previously published by Hoedemakers \& Dufraing (2015) (applying a similar numbering of the layers), some of the collected phocid remains were incorporated in Dewaele et al. (2017a), a physeterid cranium has been recently described by Alfsen et al. (in press), some early lab results were published in Adriaens (2015) and Adriaens \& Vandenberghe (2020, this volume), detailed granulometry data and additional mineralogy data in Van Herck (2019, unpublished report of bachelor project) and some photos and a short description in Houthuys et al. (2020, this volume).

All photos of the AIA outcrop in Figures 3-14 are by the first author, unless otherwise stated. A more extensive collection of photographs of AIA taken by the first author was transferred to the Geology archives of the RBINS and can be consulted upon request. In addition, a reference sample set collected by the first author allowing future lithological and micropaleontological research was deposited in the Geology Collections of the RBINS (I.G. number 34210). A reference sample set of the Middelares Hospital section was retraced and 
officially deposited in the RBINS Recent Invertebrates Collections (I.G. 33969).

Analyses of the granulometry (LS 13-320 Laser diffraction Particle Size Analyzer from Backman Coulter), mineralogy (by $\mathrm{X}$-ray diffraction (XRD)) and Fe-content (by a combination of Ultraviolet-Visible Double-Beam Photo Spectrometer and Flame-Atomic Absorption Spectrometer) were executed on a subset of 31 samples of the reference sample set in the analytical facilities of the laboratory of the Department of Earth \& Environmental Sciences of the KU Leuven by Elvira Vassilieva, Nancy Weyns and Michiel Van Herck. Pelletal glauconite contents and the roundness and sphericity of the quartz and glauconite grains were estimated by Michiel Van Herck through visual inspection (optical microscopy, point counting) of 22 thin sections made by Herman Nijs (KU Leuven). The raw data of the lab analyses can be accessed in the supplementary material.

Dinoflagellate cysts and other marine palynomorphs were recovered from another subset of the reference sample set collected by the first author and processed at the Paleontology and Paleoenvironment Group at Ghent University by Stephen Louwye. The samples (LP1-13, LP1-15, LP1-19; 40.36, 40.35 and 40.49 gr respectively) were macerated following the standard palynological maceration technique described in Louwye et al. (2004), involving subsequent acid treatments with $\mathrm{HCl}$ and $\mathrm{HF}$ for the removal of carbonates and silicates. The organic residues needed prolonged ultrasonication $(30 \mathrm{~s})$ for a better dispersal of the amorphous organic matter. The organic residues were strew mounted on slides with glycerine jelly and covered with a cover slip. The microscopic analysis was carried out on an AxioImager A1 transmitted light microscope. A target count of minimum 250 specimens, in non-overlapping traverses, was attempted under $200 \mathrm{x}$ and $400 \mathrm{x}$ magnifications. The nomenclature used is after Williams et al. (2017). The abundance of marine palynomorphs in sample LP1-13 was low and the targeted count of 250 specimens in a single slide could not be attained. Their preservation was rather poor. The abundance and preservation of marine palynomorphs in samples LP1-15 and LP1-19 was slightly better and the slides from both samples yielded enough specimens for a count of 250 specimens. All three samples hold a substantial amount of amorphous organic matter, hampering to a considerable degree the identification of palynomorphs. Reworking of pre-Neogene species was negligible in the three samples. The slides and residues were deposited within the repository of Ghent University.

All sites discussed in the text for which exists an archive at the Geological Survey of Belgium (GSB) and/or the Databank Ondergrond Vlaanderen (DOV) are listed with their codes in Table 1.

The Pliocene sequence exposed at AIA is detailed in Wesselingh et al. (2020, this volume).

\section{Field observations at Antwerp International Airport (AIA)}

\subsection{Berchem Formation}

\subsubsection{Kiel Sand Member (layer 9)}

The lowermost part of the temporary outcrop revealed the presence of at least $3 \mathrm{~m}$ of greenish light gray glauconiferous sand without observable macrofossils or large sedimentary structures that differed somewhat in color from the overlying Antwerpen Sand (Figs 2, 5A). This unit could only be observed in two small pits (northeastern corner of LP1, southwestern part of LP2) (Fig. 5A), in which unfortunately, for safety reasons, sampling or detailed observations were not possible. Their lithology allowed to refer this sand to the Kiel Sand Member of the Berchem Formation, based on the descriptions by De Meuter \& Laga (1976). A similar change in color between the Kiel and Antwerpen Sand Members was clearly documented by Hoedemakers \& Dufraing (2018) at Posthofbrug (Antwerp).

\subsubsection{Antwerpen Sand Member (layers 8, 7)}

The Antwerpen Sand Member was studied in several sections along the faces of the temporary outcrop (Figs 2, 3, 4, 5A-E). It was characterized by dark gray glauconiferous sand with shell beds containing Glycymeris baldii Glibert \& Vandepoel, 1965 as the dominant fossil. None of the sections revealed a completely identical succession. The thickness, number and lateral extent of the shell beds were highly variable over relatively short distances. Nonetheless, the upper shell bed (layer 7) was always the thickest $(50$ to $60 \mathrm{~cm}$ ) in every studied section, and all other shell beds were considerable thinner (5-15 $\mathrm{cm})$. Some of these shell beds displayed a lenticular character, others had a wavy lateral extension (see Figs $2 \& 5 \mathrm{~A}-\mathrm{B}$ ). At one spot in LP1, about halfway the upper shell bed, a lenticular sand body devoid of shells occurred.

The by far highest concentration of Glycymeris shells was observed in the upper shell bed, where hundreds of thousands of single valves were stacked on top of each other, or imbricated, mostly with their convex side upwards, with only a little sand between the valves. Convex-side-up was also the most occurring orientation of the shells in the lower beds (layer 8). Here however, the shells were less densely stacked and a bit more randomly distributed. Specimens with both valves articulated were far less common than at the Posthofbrug temporary outcrop described by Louwye et al. (2010).

Friable fragments of the gastropod Turritella eryna (d'Orbigny, 1852) were only observed in the uppermost shell bed of layer 8 (see Fig. 2, "T" in section LP 1-D), thus in a stratigraphic position similar to that at Posthofbrug.

Phosphatic concretions were observed in several levels of the Antwerpen Sand Member and did not seem to have a uniform stratigraphic distribution. While in one section, phosphatic concretions were mostly encountered in the top half of the upper shell bed, in yet another section these occurred at 10,30 and $50 \mathrm{~cm}$ below the top of the upper shell bed, and in the Turritella bed ("T").

\subsection{Diest Formation - Unit 1}

\subsubsection{Basal gravel and erosional surface (layer 6 \& base of layer 5c)}

The Diest Formation started with a coarse basal gravel of dispersed phosphorites and flint pebbles (Fig. 2). The phosphorites were dark gray to black, irregularly shaped and several centimeters in diameter. Some of them preserved internal molds of Glycymeris shells, indicating that these were most probably reworked from the underlying Antwerpen Sand. The flint pebbles were well rounded and flattened, showed a high degree of small pits and cracks related to impinging, and were generally between 1 and $3 \mathrm{~cm}$ in diameter, but pebbles up to $5 \mathrm{~cm}$ were also observed (Fig. 14A). Remarkably, the flint pebbles displayed a large array of colors. Some were white patinated, others were blue or black, and some displayed shades of green or even two or three colors. The white ones were very flat, round to elongated pastille shaped, and several of them have light blue spots. The bluish-colored pebbles were in general thicker, up to $1 \mathrm{~cm}$, those with shades of green were more irregularly shaped. Some pebbles clearly were broken in half during transport. A small number of shark teeth were found amongst the basal gravel, some of them reworked from the underlying Berchem Formation, but with the majority of them 


\begin{tabular}{|c|c|c|c|}
\hline Name & Reference & GSB code & DOV code \\
\hline \multicolumn{4}{|l|}{ Temporary outcrops } \\
\hline Antwerp International Airport & Hoedemakers \& Dufraing, 2015 & - & TO-20140101A \\
\hline Antwerp International Airport & Hoedemakers \& Dufraing, 2015 & - & TO-20140101B \\
\hline Antwerp International Airport - AIA LP1-A & this paper & $028 \mathrm{e} 0919$ & TO-20140101C \\
\hline Antwerp International Airport - AIA LP1-B & this paper & $028 \mathrm{e} 0919$ & TO-20140101D \\
\hline Antwerp International Airport - AIA LP1-C & this paper & $028 \mathrm{e} 0919$ & TO-20140101E \\
\hline Antwerp International Airport - AIA LP1-D & this paper & $028 \mathrm{e} 0919$ & TO-20140101F \\
\hline Antwerp International Airport - AIA LP2-A & this paper & $028 \mathrm{e} 0920$ & TO-20140101G \\
\hline Antwerp International Airport - AIA LP2-B & this paper & $028 \mathrm{e} 0920$ & TO-20140101H \\
\hline Antwerp International Airport - AIA LP1-1 & Wesselingh et al., 2020 & - & TO-20140101I \\
\hline Antwerp International Airport - AIA LP1-2 & Wesselingh et al., 2020 & - & TO-20140101J \\
\hline Antwerp International Airport - AIA LP2-1 & Wesselingh et al., 2020 & - & TO-20140101K \\
\hline Antwerp International Airport - AIA LP2-2 & Wesselingh et al., 2020 & - & TO-20140101L \\
\hline Middelares Hospital Deurne (AZ Monica) & Bosselaers et al., 2004 & $028 \mathrm{E} 0921$ & TO-20010401 \\
\hline Borsbeeksepoort - I BP & De Meuter et al., 1976 & $028 \mathrm{e} 0495$ & kb15d28e-B576 \\
\hline Borsbeeksepoort - II BP & De Meuter et al., 1976 & $028 \mathrm{e} 0496$ & kb15d28e-B577 \\
\hline Stenenbrug - I SB & De Meuter et al., 1976 & $028 \mathrm{e} 0497$ & kb15d28e-B578 \\
\hline Borgerhout Rivierenhof - VII B.R. & De Meuter et al., 1967, 1976 & $028 \mathrm{e} 0498$ & kb15d28e-B579 \\
\hline Borgerhout Rivierenhof - XI B.R. & De Meuter et al., 1976 & $028 \mathrm{e} 0499$ & kb15d28e-B580 \\
\hline Antwerpen Schijnpoort - V A.S. & De Meuter et al., 1976 & $028 \mathrm{e} 0501$ & kb15d28e-B582 \\
\hline Muggenberg sewer & Van Straelen, 1920 & - & TO-19200101 \\
\hline \multicolumn{4}{|l|}{ Boreholes } \\
\hline Oostmalle Pidpa & & $029 E 0249$ & kb16d29e-B276 \\
\hline Poederlee Pidpa & & 030W0300 & kb16d30w-B315 \\
\hline Mol Belchim & & 031W0221 & kb17d31w-B212 \\
\hline Retie Pidpa & & 031W0243 & kb17d31w-B228 \\
\hline Rijkevorsel & & 016E0153 & kb8d16e-B37 \\
\hline Veerle & & 060E0215A & kb24d60e-B219 \\
\hline Wijshagen & & 048W0180 & kb18d48w-B181 \\
\hline
\end{tabular}

Table 1. List of localities mentioned in the text for which there exist records in the archives of the Geological Survey of Belgium (GSB) and the Databank Ondergrond Vlaanderen (Database Subsurface Flanders; DOV), with their name, alternative name and GSB and DOV codes. being pristine and showing no signs of reworking, although some lacked their root or the apex of their crown.

In the southern part of the LP1 outcrop, an additional body of sand (layer 6) was preserved between the (eroded) top of the upper Glycymeris bed of layer 7 and the base of layer 5 (Figs 2 \& 5C-D). This layer 6 was $10-20 \mathrm{~cm}$ thick and characterized by grayish glauconiferous clayey and silty sand devoid of phosphatic concretions, gravel and fossils. Layer 6 was not observed in the northernmost part of LP1 or in LP2, where the base of the Diest Formation overlaid directly the top of the upper Glycymeris bed. The erosional surface at the base of layer 6 was very peculiar and did cut irregularly through the top of the Glycymeris beds, in small troughs, strikingly also through individual Glycymeris shells (Fig. 5C-E). Layer 6 also showed a lower degree of cementation than the upper Glycymeris bed. In one spot, some of the bioturbations of layer 5 reached the topmost centimeters of layer 6 . The lower degree of cementation and the erosional cutting into the top of the Antwerpen Sand, combined with the results of the granulometry and glauconite content (see Fig. 15 and section 5) confirmed the field hypothesis that layer 6 belongs to the (base of the) Diest Formation.

\subsubsection{Green glauconiferous sand (layers $5 c, 5 b, 5 a$ )}

A maximum of 4.30 meters of green-colored fine-grained heterogenous glauconiferous quartz sand with the near absence of carbonate particles and shells was found between the top of the Antwerpen Sand Member and the base of Unit 2 (Figs 2, 3, $5 \mathrm{~B}-\mathrm{H} \& 6 \mathrm{~A}-\mathrm{G})$. The green color is one of the main characters to set layer 5 (and especially layer 5c) apart from all other deposits exposed in the outcrop. The variable size of both glauconite and quartz grains was readily recognizable in the field with a hand lens. Dark-colored flint pebbles up to several $\mathrm{cm}$ in size occurred isolated and floating in the lowermost meter of layer 5 , the majority of these were observed between 30 and $65 \mathrm{~cm}$ above the base of layer 5 .

A clay and silt fraction was present throughout layer 5, but was more readily observable in its lower half, called layer $5 \mathrm{c}$. Here, on freshly exposed mechanically dug semi-vertical walls, the sediment displayed a 'mottled' appearance, characterized by alternating patches of more or less clay-rich sand which were somewhat horizontally structured (Fig. 5F). Along the borders of these patches, the clayey fraction was frequently somewhat smeared out along the semi-vertical walls, while the same smearing was much less observed along subhorizontal cuts 


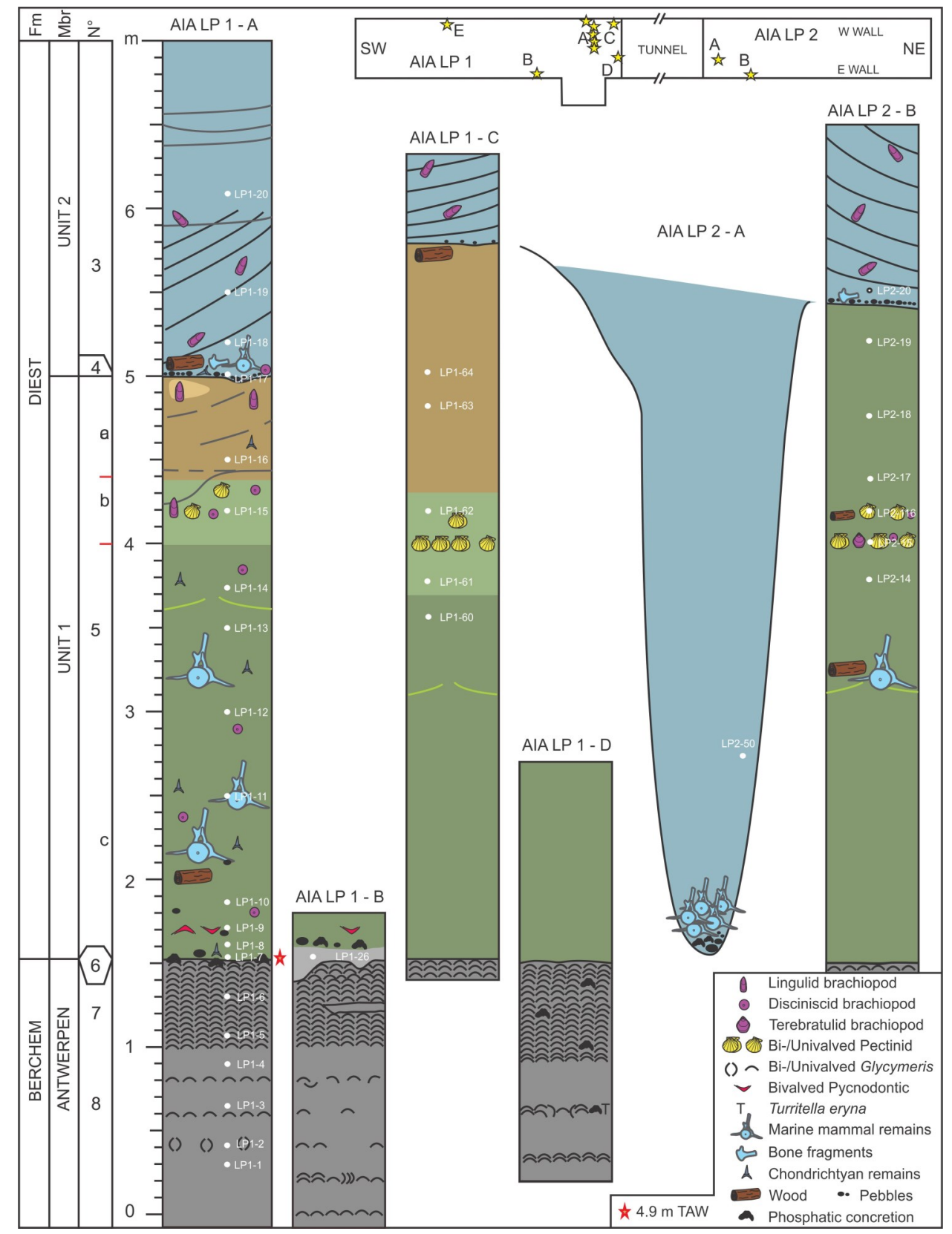

Figure 2. Stratigraphic logs of the AIA outcrop with indication of their location, and with detailed positioning of the samples taken for sedimentological, mineralogical and micropaleontological analyses. Due to the absence of a single well accessible vertical wall along which the entire section could have been logged onto in all of its details, the section is represented by one major litholog drawn within a reduced sector of LP1 and supplemented by several additional partial lithologs spread across LP1 and LP2 in order to reveal the lateral variation of the thicknesses of individual layers and sedimentary structures, like the distribution of the Glycymeris beds in layer 8 , the presence or absence of layer 6 , and the depth of the erosional scouring of the base of Unit 2. In the absence of clear boundaries for the base and top of layer $5 b$, the different coloration of layer $5 \mathrm{~b}$ was used as a guide. In addition, some of the pseudo-sedimentary structures, like e.g. the undulating clay drape (in green) and the sub-horizontal pseudolayering in the upper part of Unit 2 in LP1-A (in gray) are also drawn onto the lithologs.

through this interval (compare Fig. 6B with Fig. 5F). Careful scraping off the semi-vertical walls with hand tools failed to identify sedimentary structures such as layering that could be responsible for this 'mottled appearance'.

Bioturbation was observed throughout layer 5c, with different types being present. The by far most apparent and abundant bioturbation structures were subvertical and subhorizontal cylindrical burrows in which the inner fill was lighter colored, due to a lower amount of glauconite, and the outer rim darker green or reddish-brown colored, resulting from a higher glauconite content. The display of colors made subhorizontal cuts through the middle part of layer 5c almost resemble military camouflage blankets (Fig. 6B). Bioturbation was much less intense in the lower $40 \mathrm{~cm}$ of layer $5 \mathrm{c}$. Here, most of the observed bioturbation consisted of long subvertical burrows tunneling deep down from levels more than half a meter above (Fig. 5C-D, G-H).

In this less bioturbated interval, about $10-20 \mathrm{~cm}$ above the base of layer $5 \mathrm{c}$, a single bed of shells was observed, in which thin-shelled and relatively small $(<10 \mathrm{~cm}$ diameter $)$ pycnodontid oysters occurred. The observed specimens were found articulated, with their inner valve being several times thinner than the outer valve. All shells were found lying next to each other, none were found growing on top of each other. This shell bed had a somewhat patchy distribution along the outcrop, and, only in LP2, Mimachlamys angelonii (de Stefani \& Pantanelli, 1880) was found to occur in this level. Apart from these beds, no shells were found in layer $5 \mathrm{c}$.

The lower part of layer 5c, especially between 60 and 100 $\mathrm{cm}$ above its base, was extremely rich in marine mammal fossils; from isolated periotica to a few vertebrae in connection to nearly complete skeletons. Ichthyological remains were very common, mostly isolated vertebrae or other osteological remains of teleosts, but isolated teeth of elasmobranchs also occurred (see Hoedemakers \& Dufraing, 2015, plates 1-2). Wood logs also occurred relatively abundantly within this interval.

In the upper part of layer $5 \mathrm{c}$, a $2-3 \mathrm{~mm}$ thick 'undulating clay drape' was observed along the entire outcrop that slightly protruded from weathered and windblown walls at the AIA outcrop, with $20-30 \mathrm{~cm}$ between the highs and lows and about 1 $\mathrm{m}$ spacing between successive peaks (Fig. 6C-F). It occurred at slightly variable heights measured from the basis of layer 5 , the latter not being even either (see Fig. 2). On freshly scraped-off 


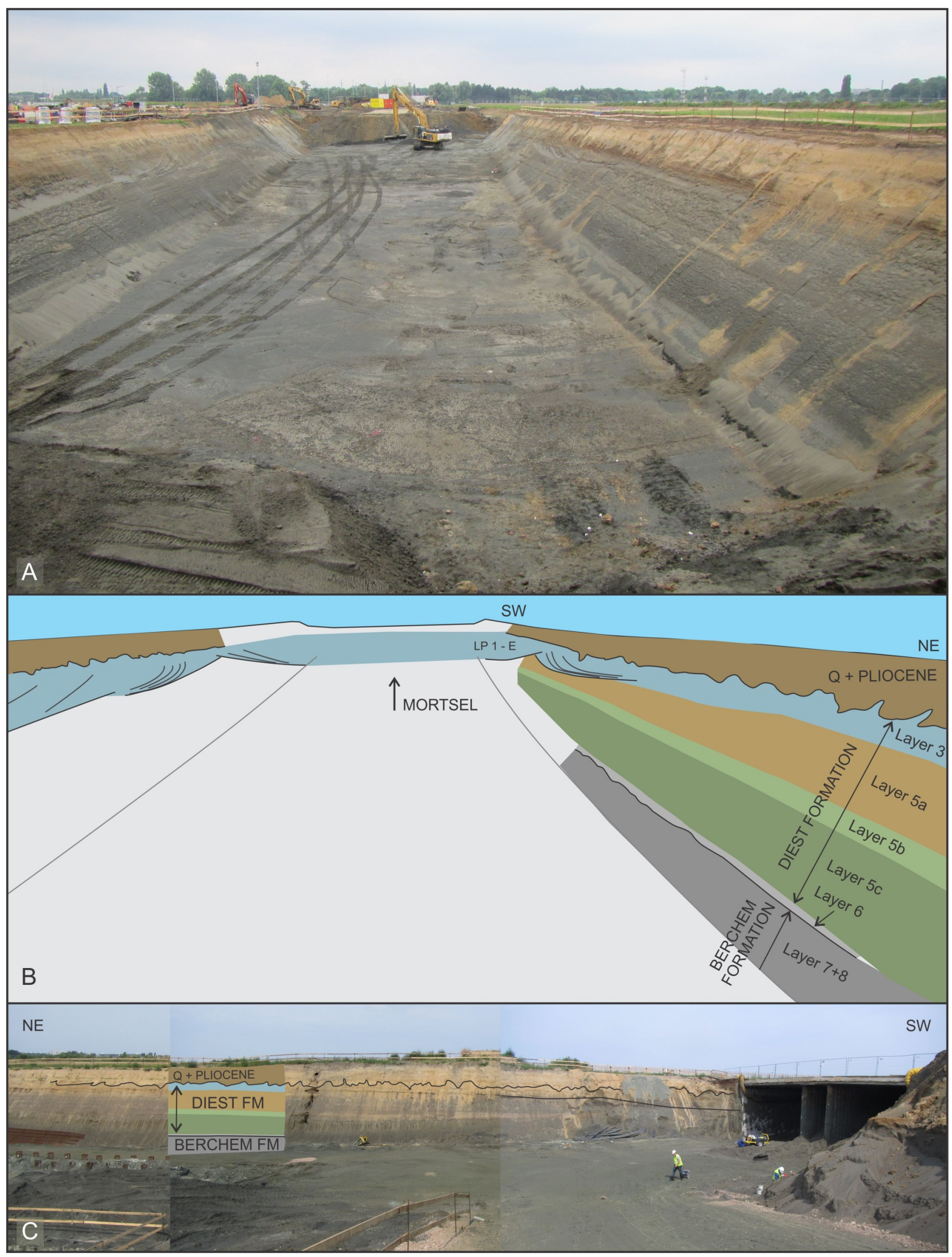

Figure 3. Observations at AIA outcrop (part 1). Large-scale stratigraphic framework of LP1. A-B. General over view of the middle and southern part of LP1. C. W wall of the middle and northern part of LP1, and tunnel entrance. 


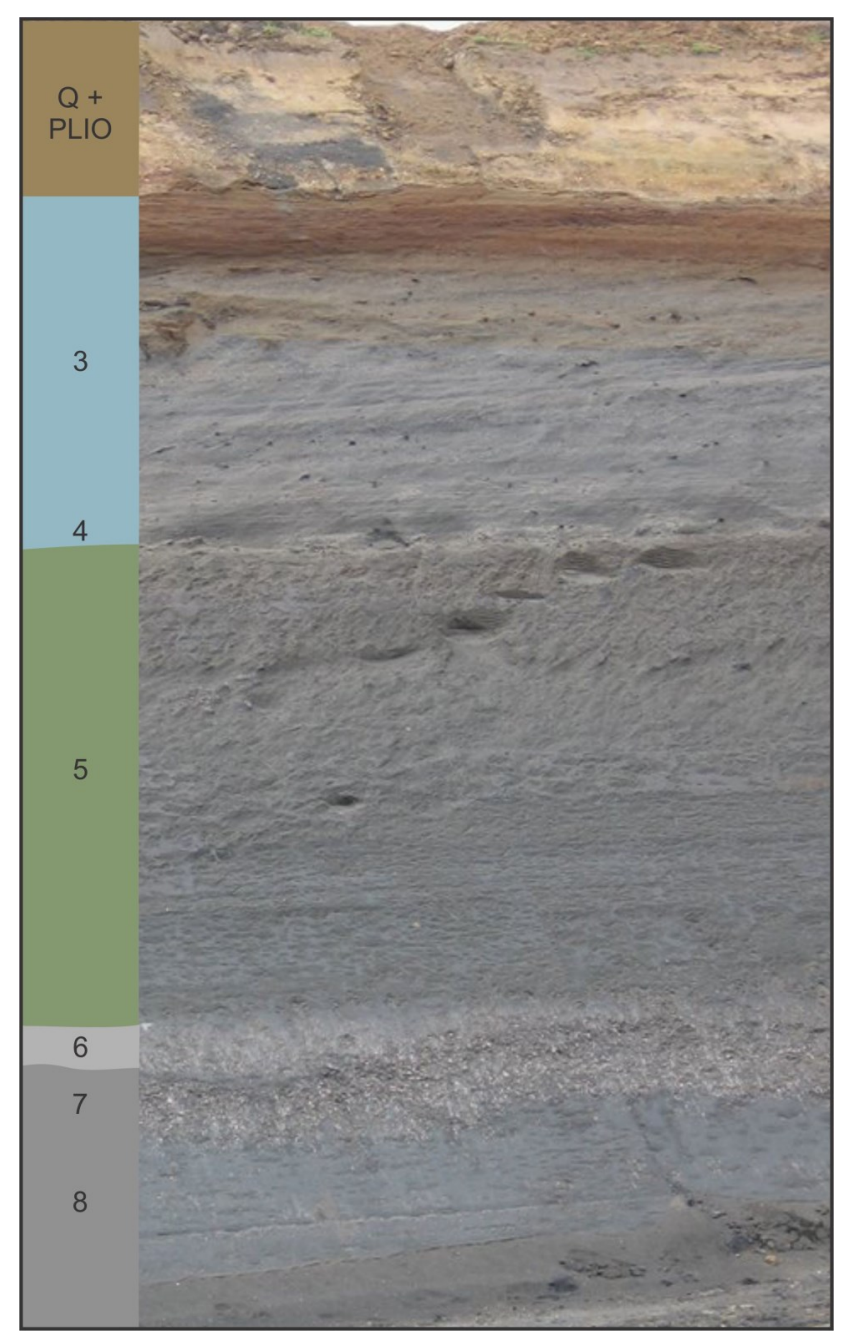

Figure 4. Observations at AIA outcrop (part 2). I. Overview of the sequence exposed at AIA LP1, W wall, just south of section LP1-B (see Fig. 2). Photo credit Jef De Ceuster.

walls, this 'clay drape' exposed a vibrant green color, comparable to that of weathered glauconite (Fig. 6E), it ran through bioturbation structures (Fig. 6F). In addition, no difference in grain size or clay content was observed at this level. All these observations led to assume that the 'undulating clay drape' is a post-depositional weathering phenomenon, and not a primary sedimentary structure.

At 2.30 to $2.50 \mathrm{~m}$ above the base of Unit 1, for an interval of about $40-50 \mathrm{~cm}$, the sediment had a slightly different color, being more whitish to yellowish-white on windblown walls or more reddish-brown colored when hand-scraped (Fig. 6G). On relatively freshly excavated walls, this interval did not seem to have a clearly marked base nor top, while on more weathered walls, its boundaries were more readily discernable and more easily traceable as a subhorizontal different colored band (Fig. $6 \mathrm{G})$. Some variation in thickness and of its distance to the base of layer 5 (Fig. 2) was observed. We assume that this postsedimentary discoloration resulted from a slightly different original lithology, and therefore termed this interval as layer $5 \mathrm{~b}$. Two shell beds about $15-20 \mathrm{~cm}$ apart occurred within this layer $5 \mathrm{~b}$ (Fig. 6G-H). The fauna of both of these beds is dominated by pectinid bivalves (Figs 6H, 7). In the lower bed, the shells were more frequently articulated compared to the upper bed. Nearly all shells had some reddish sand encrusting and were stained red (Fig. 14D-E). The most abundant species in this bed is Mimachlamys angelonii.
A maximum of $1.5 \mathrm{~m}$ of greenish heterogenous glauconiferous sand with yet another slightly different staining on weathered walls occurred above $5 \mathrm{~b}$ (Fig. 3). In many parts of the outcrop, this layer $5 \mathrm{a}$ was absent, due to erosional scouring of the overlying Unit 2. Within the uppermost preserved half meter, some sand was lithified into a friable sandstone. Macrofossils were only rarely found. Amongst them were a few reddishly encrusted bivalve shells (?pycnodonts), and two large chondrichthyan vertebrae. Bioturbation was omnipresent, much as in layers $5 \mathrm{c}$ and $5 \mathrm{~b}$.

\subsection{Diest Formation - Unit 2}

\subsubsection{Erosional basal gravel (layers 4, X)}

The base of Unit 2 is marked by an erosional surface, evidenced by its undulating nature and the presence of a basal gravel (layer 4).

The undulating nature relates to the presence of large, wide and asymmetrical (as displayed along the outcrop walls) troughs, sometimes cutting quite deep into the underlying Unit 1 (Figs 2, 3A-C, 4, 8A-B, 9A-B \& 10A). Along the majority of the outcrop, the base of the troughs did not descend below layers $5 \mathrm{a}$ and $5 \mathrm{~b}$, but in the southernmost part of LP2, near the tunnel's entrance, the erosional base reached the top of the Berchem Formation, having removed the entire Unit 1.

The basal gravel (Figs 10A \& 14B-C) varied in thickness from nearly non-existent to up to $10 \mathrm{~cm}$ thick in the deeper parts of the troughs. Its pebbles were small-sized and sat in a sandy matrix just above the erosional surface. White-colored quartz pebbles ranging up to a few $\mathrm{mm}$ in diameter overwhelmingly dominated. These were well rounded and generally had an elongated shape. Most were milky white colored at their outer surface, while others were translucent. The latter ones tended to show less signs of transport and reworking. Yet another type of pebbles included eroded fragments of marine mammal bones and brachiopod shells, shark and ray teeth, most with obvious signs of some reworking, but still retaining a good physical preservation so that the transportation may not have been across considerable distances. Fragments of light gray to whitishcolored friable sandstone rich in carbonate and clay also occurred.

At the one spot near the tunnel's entrance in LP2 where all of layer 5 was removed, an enormous concentration of shark teeth and marine mammal bones occurred at the base of the trough. This spot was marked by an ' $\mathrm{X}$ ' in Hoedemakers \& Dufraing (2015, fig. 1A), and in accordance, the material collected at the base of this trough is marked here as from layer $\mathrm{X}$. Most but not all the bones were somewhat damaged, with e.g. vertebrae missing their apophyses and especially the smaller tympanics showing signs of abrasion. Still, several pairs of periotics were found closely together, and the overall quality of most of the shark teeth was still very good to good, with pristine enamel and nearly perfectly preserved roots, indicating that this accumulation of vertebrate fossils may not have moved over long distances and must have originated from the local erosion of layer 5. One peculiar find was a large Otodus megalodon tooth (coll. Bert Gijsen) from which on one side a few mm was eroded away while the remainder of the tooth was in pristine condition. Further on, reddish-stained pieces of bivalves and brachiopods, echinoids, balanid cirripeds and bryozoans (rare) were found, plus one bone of a land mammal.

\subsubsection{Troughs with foresets in heavily bioturbated bluish glauconiferous sand (layer 3)}

The troughs were filled with bluish-colored heterogenous glauconiferous quartz sand arranged in foresets of varying direction, inclination and thickness. Individual layers were a few 


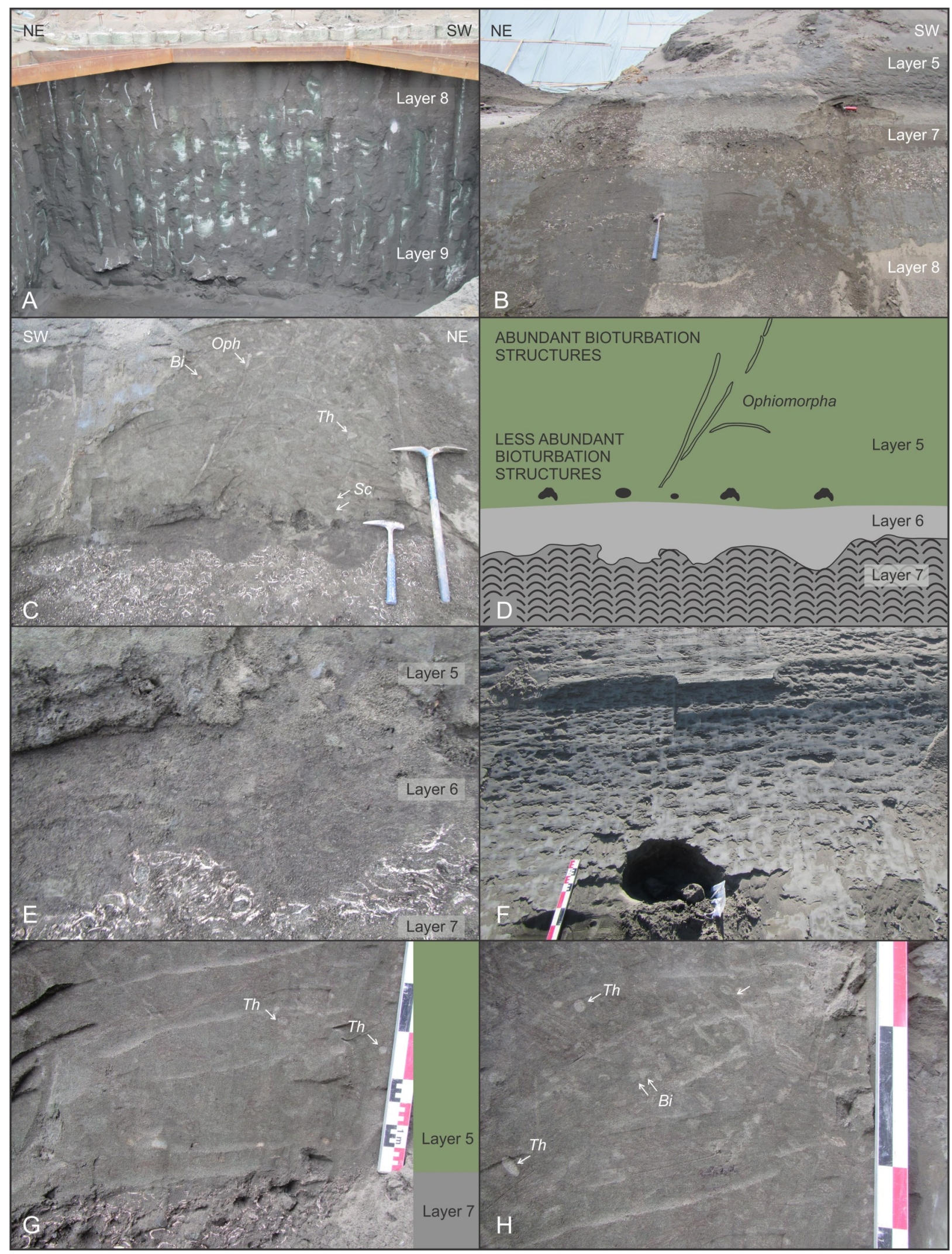

Figure 5. Observations at AIA outcrop (part 3). Abbreviations: Bi - Bichordites, Oph - Ophiomorpha, Pl - Planolites, Sc - Scolicia, Th Thalassinoides. Hammer measures $33 \mathrm{~cm}$, pickaxe $65 \mathrm{~cm}$. Scale bar (G-H) indicates 1,5 and $10 \mathrm{~cm}$. A. Lowermost part of the outcrop in the NE corner of LP1 exposing the lower part of the Antwerpen Sand Member (layer 8) and the underlying Kiel Sand Member (layer 9) of the middle Miocene Berchem Formation. About $3 \mathrm{~m}$ deep. B. Upper part of the Antwerpen Sand Member with thin Glycymeris beds (layer 8) and a thick upper Glycymeris bed (layer 7). Note that halfway layer 7, a lenticular body of sand occurs that seems completely devoid of shells, and that at the erosive contact between the Berchem and Diest Formations, layer 5c directly overlays the Antwerpen Sand. C-D. Erosive contact between the Berchem and Diest Formations along the W wall of LP1, with the presence of additional layer 6 between the top of the Antwerpen Sand (layer 7) and the gravelly base of layer $5 \mathrm{c}$. The lower part of $5 \mathrm{c}$ is less intensely bioturbated, with deep burrows. E. Detail of the erosive contact figured on C-D. The boundary with the Antwerpen Sand is very sharp, and several Glycymeris shells are sharply cut through. F. Mottled appearance of layer $5 \mathrm{c}$ on a freshly dug semi -vertical wall (E wall LP1, southern part). The hole represents the spot where a well-preserved skull of an Odontocete was discovered. G-H. Erosive contact between the Berchem and Diest Formations $(\mathrm{G})$ and the lower part of layer $5 \mathrm{c}(\mathrm{G}-\mathrm{H})$ at the tunnel entrance in LP1. Layer 6 is again absent, so that layer $5 \mathrm{c}$ directly overlays layer 7 . The lower $30 \mathrm{~cm}$ of layer $5 \mathrm{c}$ is also lesser intensely bioturbated $(\mathrm{G})$ than the higher parts of layer $5 \mathrm{c}(\mathrm{H})$. 


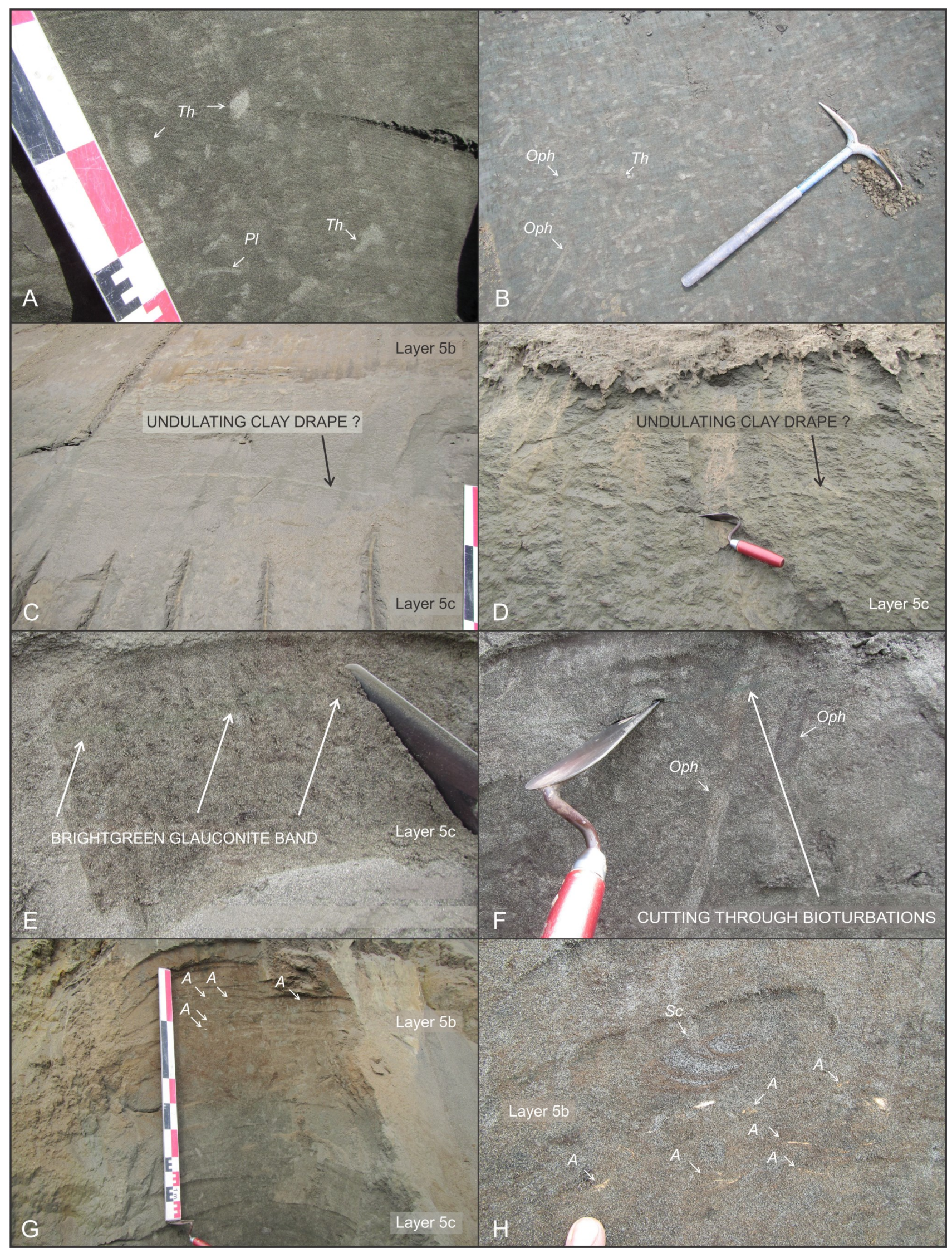

Figure 6. Observations at AIA outcrop (part 4). Abbreviations: A - Mimachlamys angelonii, Ms - Macaronichnus segregatis, Msd - M. segregatis degiberti, $\mathrm{Sc}-$ Scolicia, Ta - Taenidium. Scale bar indicate 1,5,10 and $20 \mathrm{~cm}$. Pickaxe measures $65 \mathrm{~cm}$, trowel handle (red) $10 \mathrm{~cm}$, trowel metal blade $15 \mathrm{~cm}$ and finger $2 \mathrm{~cm}$. A. Different types of bioturbation in layer $5 \mathrm{c}$ (LP1, northern part). B. Subhorizontal section through an intensely bioturbated layer 5c (LP2, southern part). C-F. Upper part of layer 5c with the 'undulating clay drape', well visible as a thin 'clayey layer' along windblown walls of LP1 and LP2 (C-D), or as a thin bright green-colored glauconitic band cutting through bioturbations on freshly scraped off walls. Trowel handle measures $12 \mathrm{~cm}$. G. Upper part of layer $5 \mathrm{c}$ and layer $5 \mathrm{~b}$, with the brownish staining of the sediment of layer $5 \mathrm{~b}$. The small elongated white spots in layer $5 \mathrm{~b}$ represent pectinid shells that are cut through. H. Pectinid bivalves and trace fossils in layer 5b, LP2, E-wall. 


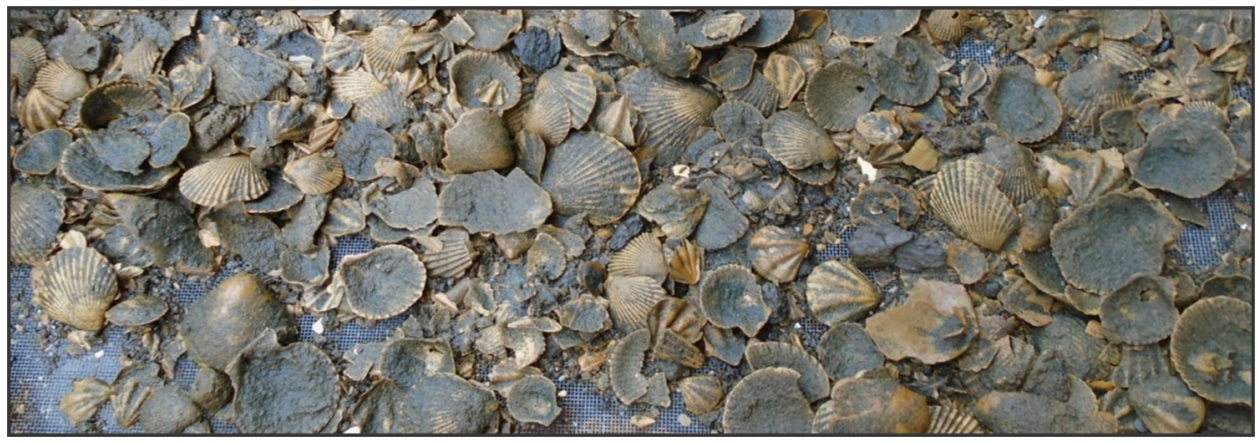

Figure 7. Observations at AIA outcrop (part 5). Sieving residue of layer 5b with Mimachlamys angelonii abundantly present, next to other pectinids, terebratulid shells. Most shells are 3 to $5 \mathrm{~cm}$ diameter. Photo credit Jef De Ceuster.

$\mathrm{mm}$ up to $50 \mathrm{~cm}$ thick (Figs 4, 8A-B, 9A-B, 10A-D \& 11A-H). Grain size and glauconite content varied somewhat between individual foreset beds, but in general, the bluish-colored sand was coarser-grained and better-sorted and containing a lower amount of silt and clay than the underlying greenish-colored sand of layer 5 . Much as throughout layer 5 , the heterogeneity of the grain size was easily recognizable through a hand lens.

Several stacked cross beds with erosional bounding surfaces were identified on the somewhat weathered and windblown walls of LP1 and LP2 (Figs 3 \& 8A-B). In LP2, at least three could be identified (Figs 8A-B). In LP1, although less obvious, three sets seem to have been present here as well. In both pits, the oldest generation produced the largest widest troughs. The trough's long axes were roughly W-E. Some variation may have been present, based on the slightly different cross section of the troughs on the outcrop walls (e.g. Figs 8A-B). Only a few small walls perpendicular to the main outcrop direction allowed to identify that the average dip direction of the foresets was ESE

\section{(e.g. Fig. 11A).}

The foreset beds were heavily bioturbated, displaying a different trace fossil association than that of Unit 1 (Figs 10A-D \& 11A-H). Some of the original layering may have been effaced or become difficult to observe due to the intensity of the bioturbation in some of the levels, while at the same time the somewhat rhythmic bioturbation pattern in the foreset beds created an additional pseudolayering. The most abundant type of bioturbation structures is the one in which the tracemaker separated glauconite from quartz, resulting in white tubes filled with quartz sand and dark blue walls made up of glauconite.

Apart from fragments of lingulid brachiopods, macrofossils were quite rare within the foreset beds.

3.3.3. Southernmost trough with bryozoans, friable sandstone and concretions (layer 4b)

The southernmost trough of LP1 revealed an additional level not observed in the other troughs. It occurred 5 to $10 \mathrm{~cm}$ above the

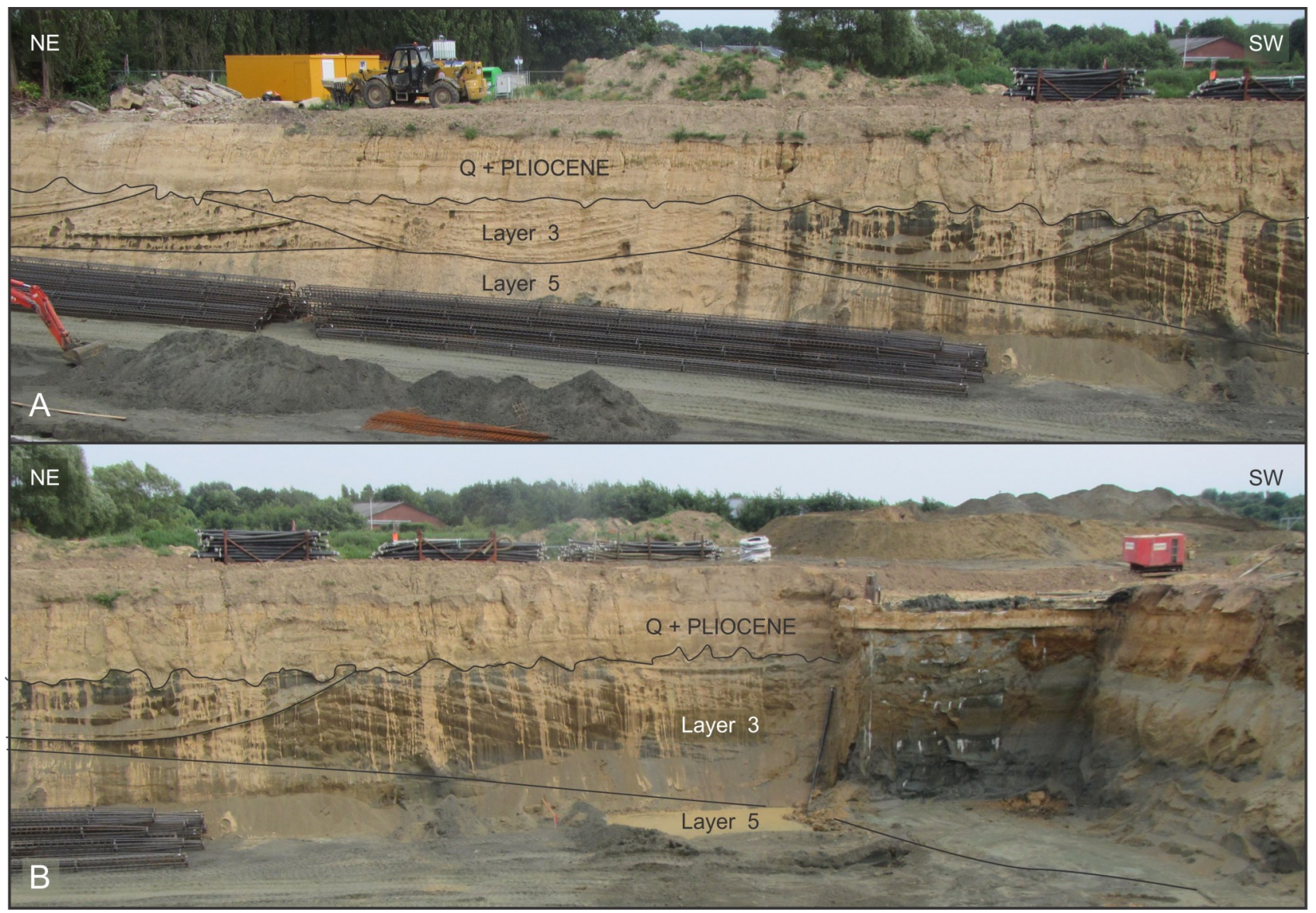

Figure 8. Observations at AIA outcrop (part 6). A-B. Large-scale sedimentary structures in Unit 2 along the E wall of LP2, with three generations of troughs. A bit more to the SW of the photo of figure B, near the tunnel entrance, the erosional base of the trough reached top of the Antwerpen Sand and an enormous accumulation of shark teeth and marine mammal bones was found in it (= layer $\mathrm{X}$ ). 


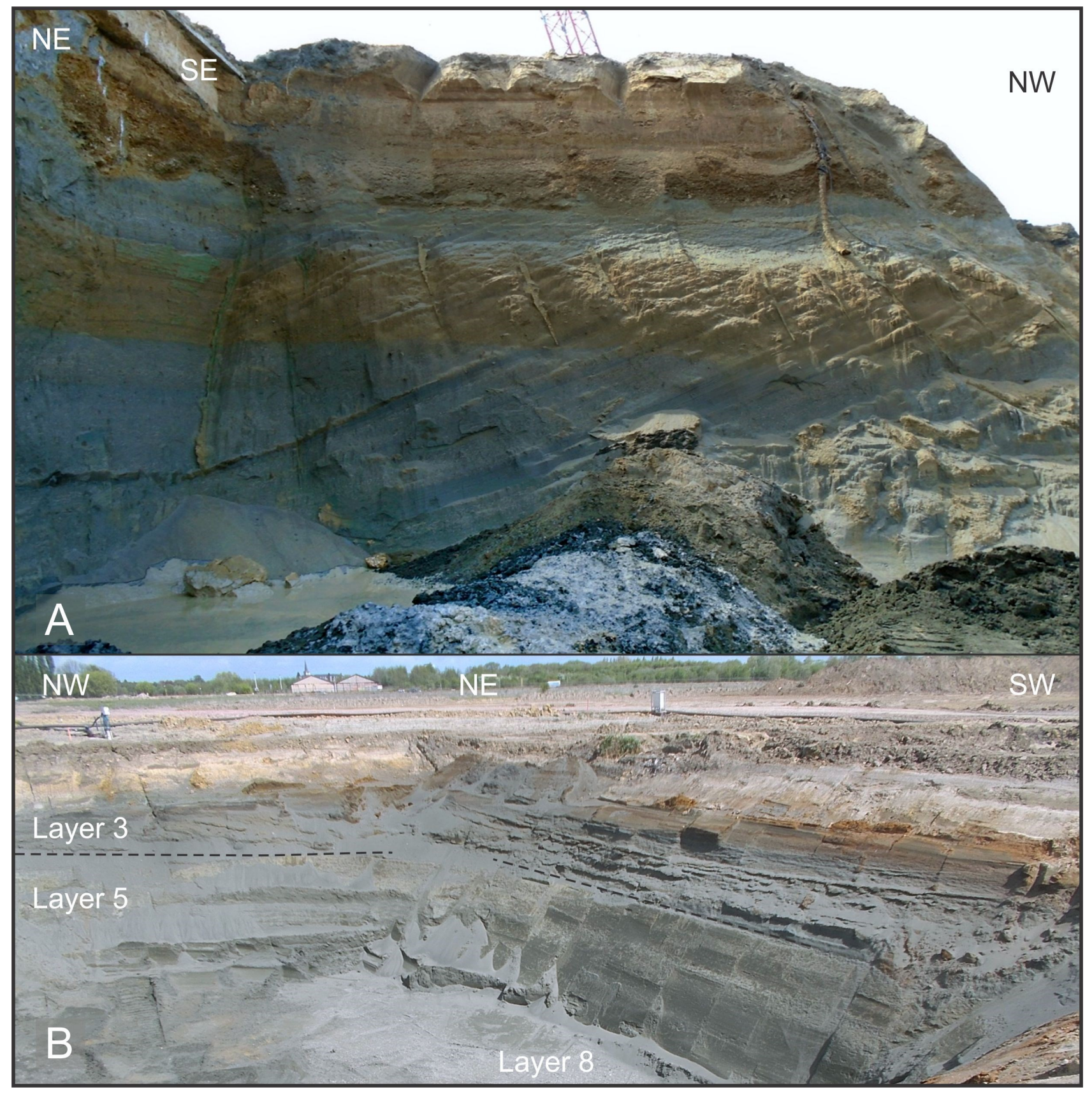

Figure 9. Observations at AIA outcrop (part 7). A. Dipping for esets in a wall perpendicular to the main direction of the outcrop. Continuation of the large trough figured on Fig. 8B. LP2, southern part. Photo credit Jef De Ceuster. B. Large-scale sedimentary structures of Unit 2, with low wide-open trough and dipping foresets. NE corner of the dugout in the NE corner of LP1 (see Figs 1, 2). Photo credit Jef De Ceuster.

base of the trough and extended from its deepest parts up along its upsloping walls for at least one meter of height. Higher-up on the slope, this additional level seemed to disappear. A schematic drawing is given in Figure 12A.

The additional level was characterized by the presence of friable sandstone, friable calcareous concretions (Fig. 12B) and bryozoans (Fig. 12C). The sandstone and concretions were restricted to the deepest parts of the trough, while the bryozoan colonies were found throughout.

The friable sandstone was light gray colored and carbonate cemented, and ranged from a few $\mathrm{cm}$ up to $10 \mathrm{~cm}$ in thickness and up to $30 \mathrm{~cm}$ in size. Next to complete bryozoan colonies, the sandstone also yielded more fragmentary bryozoans, imprints of now-dissolved shells of small-sized bivalves, some of them in butterfly position, and terebratulid brachiopods, some of them encrusted with bryozoans. Whitish-yellowish to orange colored friable carbonate concretions were found in-between the sandstone (Fig. 12B). In the loose sand between the sandstone and concretions, similarly colored patches of non-concretional sand occurred (Fig. 12D), which did not reveal clues on their possible origin either.

Bryozoan colonies were quite well preserved when encased in the friable sandstone. Those found in loose sediment heavily suffered from decalcification and immediately crumbled away, making extraction or study impossible. However, only a single layer of bryozoan colonies was observed, so that possibly, these colonies may have been buried in or near their life-positions.

Because it was nearly impossible to fully separate this layer from the underlying basal gravel during sampling, the samples for macro- and mesopaleontological research were labelled as originating from layer $4 \mathrm{~b}$.

An additional brownish discoloration of the first $20-30 \mathrm{~cm}$ of the sediment underlying this trough was also observed (Fig. 12A). 


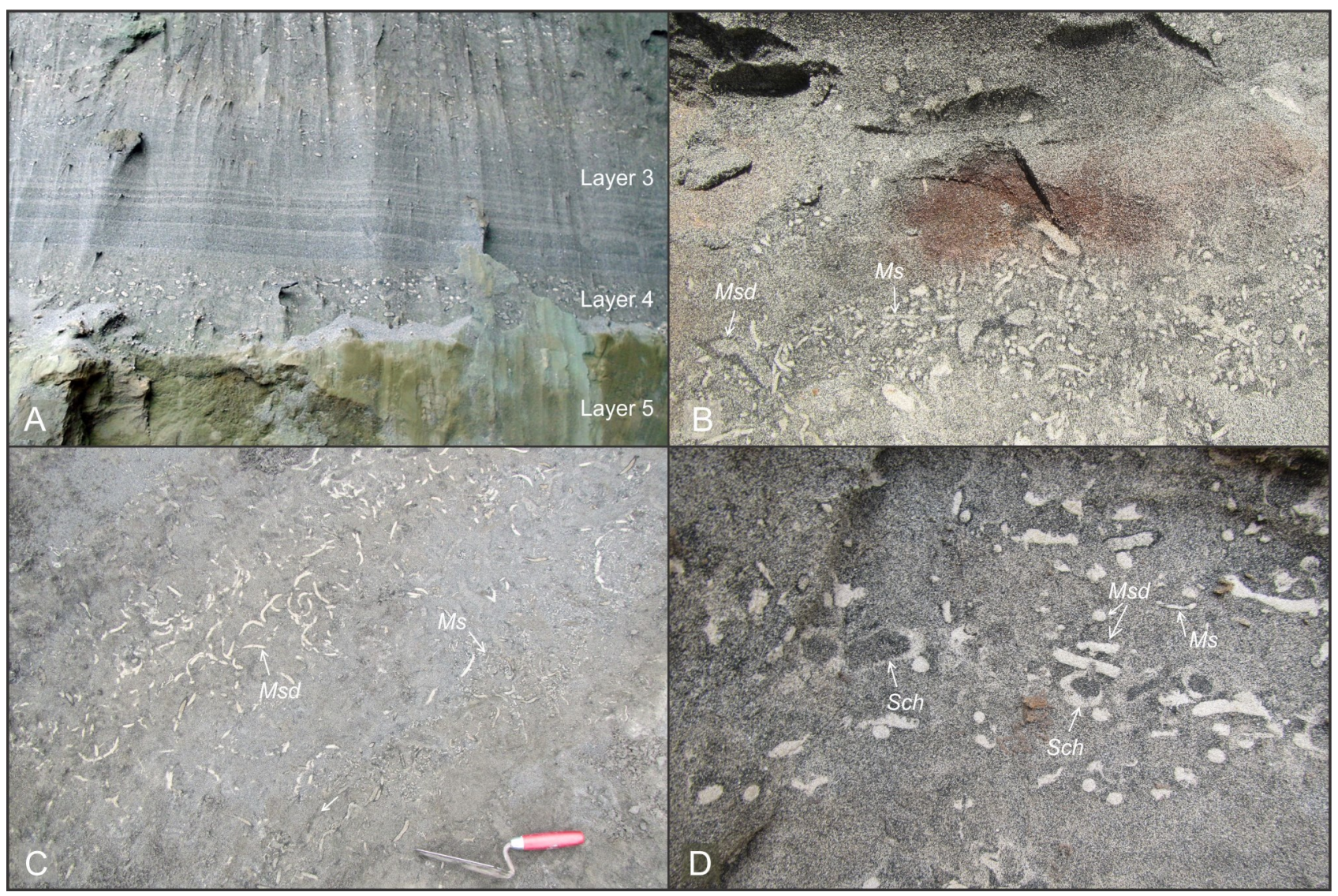

Figure 10. Observations at AIA outcrop (part 8). Abbreviations: Sch - Schaubcylindrichnus (larger form), Ms - Macaronichnus segregatis, Msd M. segregatis degiberti. Trowel handle (red) $10 \mathrm{~cm}$, trowel metal blade $15 \mathrm{~cm}$. A. Detail of the contact between Unit 1 and Unit 2 in the southern part of LP2, with well-developed layer 4 and beautifully preserved bedding in the lesser bioturbated foresets. Photo credit Jef De Ceuster. B. Intensely bioturbated part of layer 3 with Fe-carbonate concretion (siderite) about $20 \mathrm{~cm}$ in diameter (LP1, middle part, W wall). C. Trace fossils in a subhorizontal cut of the southernmost trough of LP1. D. Trace fossils 30-50 cm above the base of layer 3, LP1, northern part, NE wall.

\subsection{Pseudosedimentary structures - Post-sedimentary structures}

At AIA, quite many of the structures and features that were observed within Units 1 and 2 turned out to be related to postdepositional weathering rather than to original sedimentary structures. One of these so-called pseudosedimentary structures was the 'undulating clay drape' observed within the upper part of layer $5 \mathrm{c}$ and described above (Fig. 6C-F). Others were the discolorations of the sediment within layers $5 \mathrm{~b}$ and $5 \mathrm{a}$ (Fig. $6 \mathrm{G}$ ), or the discoloration of the sediment below the base of Unit 2 (Fig. 12A) and a thin layer of bluish-green discolored glauconite at the erosive contact between Unit 2 and Unit 1 (Fig. 13G-H) at the southernmost trough in LP1, or the subhorizontal pseudolayering created by deposition of Fe-oxides under meteoric conditions in the topmost meter of Unit 2 (Figs 2, 9A \& 13C-F).

In some of the troughs of LP2, secondary deposition was also responsible for the formation of sandstone and ironstone in some of the foreset beds in Unit 2 (Fig. 13A-B). Weathering of glauconite locally also resulted in a much more clayey appearance of the sediment of the main body of Unit 2 .

Yet another type of discoloration had a very spotty distribution, in irregular small- (Fig. 10B) and larger-scale (Fig. 13C-D) lenses of reddish-brown stained sediment, related to the deposition of Fe-carbonate (viz. siderite).

While some of these pseudosedimentary structures must have had their origins in subtle differences in the originally deposited sediment (e.g. the different coloration of layers $5 \mathrm{c}, 5 \mathrm{~b}$ and 5a), others are clearly fully related to post-depositional alteration. Also important to note was the sheer lateral extent of the outcrop which was a major factor in helping to discriminate between real- and pseudo-sedimentary structures. In a much smaller outcrop, without being able to verify the features over considerable distances, some of these pseudo-sedimentary structures may have been mistakenly interpreted as true sedimentary signals.

\section{Paleontological observations}

\subsection{Invertebrate macrofauna}

\subsubsection{Scarcity of shells and absence of aragonite producers}

In large contrast to many other Neogene deposits of the Antwerp area, the number of invertebrates collected from the AIA outcrop was extremely low, with aragonitic shells being completely absent, except in layers $7-8$. With the additional absence of shell ghosts, the presence of molds of originally aragonitic bivalves in the friable sandstone found above the base of the southernmost trough of Unit 2 and some rare molds of gastropods in layer 3 formed the only direct indicators of their original presence. Thus, their absence must, at least partially, relate to post-depositional decalcification. In addition, the fragile nature of the pycnodontic oysters at the base of layer $5 \mathrm{c}$ and the reddish staining and encrusting by Fe-carbonate of the shells in layer $5 \mathrm{~b}$ were additional indicators for this decalcification. The intensity of the decalcification must also have varied locally, e.g. with the shells of the two Mimachlamys beds being much more fragile and less reddish stained in LP1 than in LP2.

While decalcification may have largely biased the taphocoenosis, it does however not explain the fairly low 


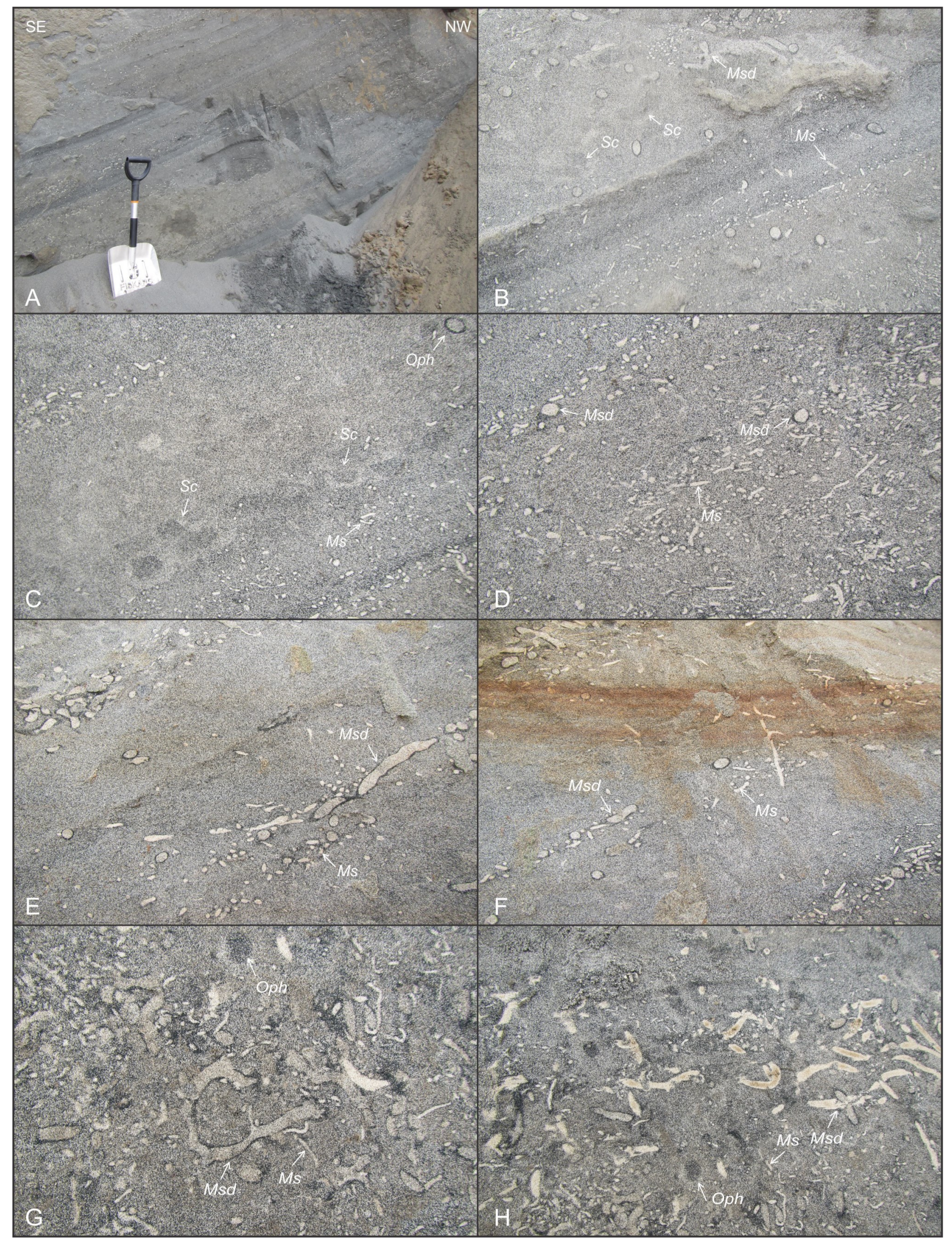

Figure 11. Observations at AIA outcrop (part 9). Abbreviations: Ms - Macaronichnus segregatis, Msd - M. segregatis degiberti, Oph Ophiomorpha. Shovel measures $74 \mathrm{~cm}$. Photographic illustrations of the typical ichnofabric and layering within the troughs with foresets of Unit 2 at AIA. A-E. Details of the same vertical face with an orientation of $90^{\circ}$ on the western face in the southern part of LP1, revealing cyclic patterns of sedimentation and bioturbation and different types of bioturbations. F. Staining by Fe-oxides-hydroxides creating a subhorizontal pseudo-layering in inclined foreset beds of Unit 2 on the same wall as figured in A-E. G-H. Subhorizontal cuts through bioturbations in the southernmost trough of LP1. Largest Maraconichnus are about $8 \mathrm{~mm}$ in diameter. 


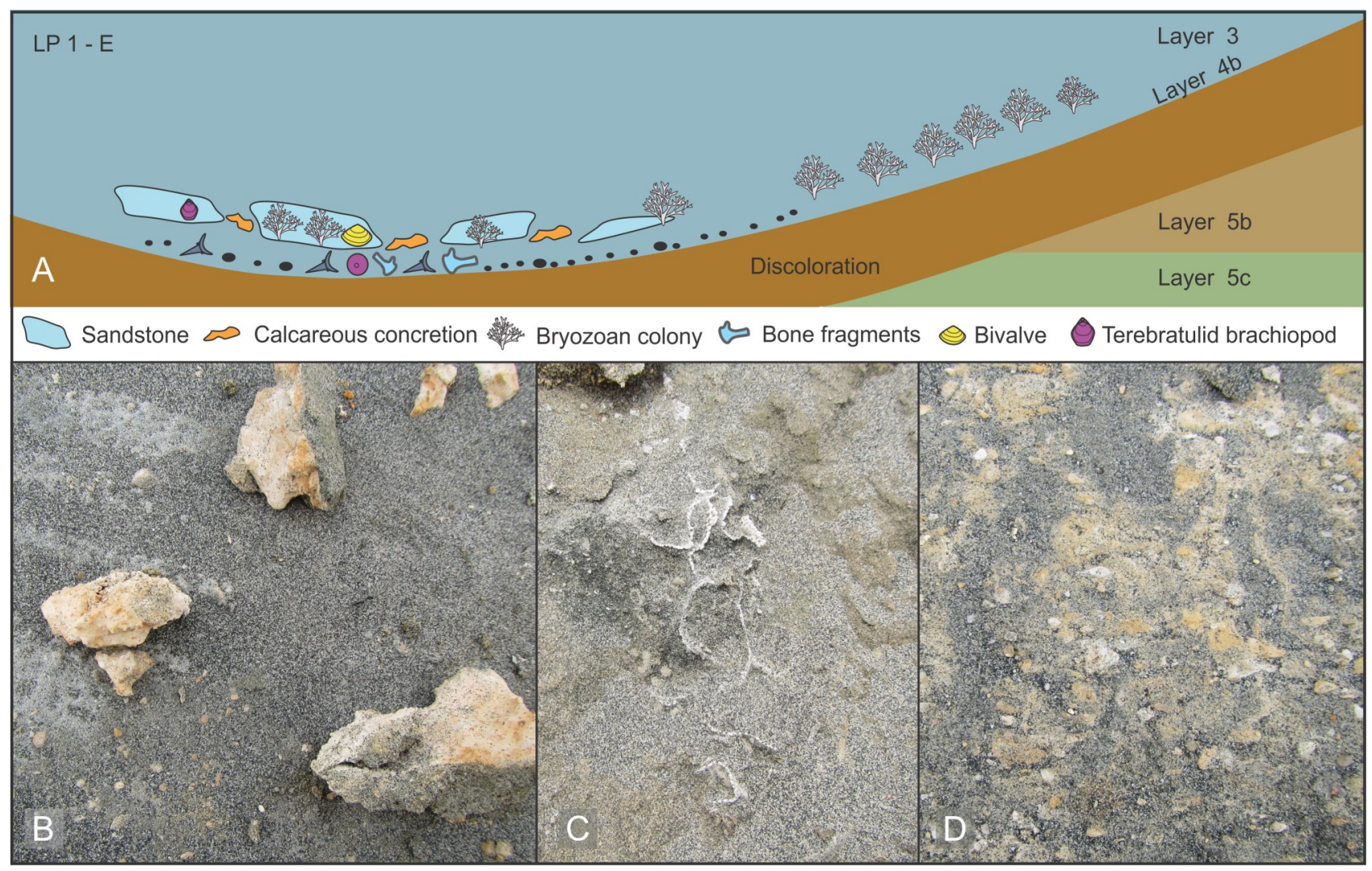

Figure 12. Observations at AIA outcrop (part 10). A. Schematic drawing of the infill of the southernmost through of LP1, with a gravelly base with reworked fossils, and a level with bryozoan colonies extending up the slopes of the trough. In the deepest parts, friable sandstone with a faunule of small bivalves and well-preserved bryozoan colonies occur next to friable calcareous concretions. A brownish staining of the first $20-30 \mathrm{~cm}$ of the sediment underlying the trough was observed. Remark that the foreset beds inside the trough are not drawn, although these were present. Samples for the collecting of macro- and mesofossils from the base of this trough were labelled as from layer $4 \mathrm{~b}$. B. Friable carbonate concretions about $5 \mathrm{~cm}$ in diameter found $10 \mathrm{~cm}$ above the base of the southernmost trough of LP1. C. Bryozoan colony along the slopes of the southernmost trough of LP1. About $5 \mathrm{~cm}$ diameter. D. Subhorizontal cut through the lowermost $10 \mathrm{~cm}$ of the deeper parts of the southernmost trough of LP1. Some of the orangeto yellow-colored spots are friable concretions, other similarly colored stains in the sand. Spots are few $\mathrm{cm}$ in diameter.

numbers of calcite shells in the shell beds, and even more in the remainder of layer $5 \mathrm{c}$ and layers $5 \mathrm{a}$ and 3 . In the latter, their absence must at least partially reflect environmental conditions. The pycnodontic bed however, is a single bed of mostly articulated shells of nearly the same moderate size lying wellspaced from each other, hinting for life burial rather than condensation. The same seems to apply to the lower of the two pectinid beds in which articulated specimens were common.

\subsubsection{Bivalves and gastropods}

From the pycnodontic bed in the lower $20 \mathrm{~cm}$ of layer $5 \mathrm{c}$, only some fragile and incompletely extracted fragments of pycnodontid oysters, tentatively identifiable to Neopycnodonta navicularis (Brocchi, 1814) or closely allied species, were recovered. In LP2, also abundant Mimachlamys angelonii were found within this level.

From the two pectinid beds of layer $5 \mathrm{~b}$, reddish-stained shells (Figs 7, 14D-E) of the pectinids Mimachlamys angelonii, Pseudamussium inflexum (Poli, 1795), Pseudamussium lilli (Pusch, 1837) and Korobkovia woodi (Nyst, 1861) were collected, with the former one being much more abundant than the latter three.

From the sandstone above the base of Unit 2 (i.e. layer $4 \mathrm{~b}$; see Fig. 12A), only a small number of relatively small originally aragonitic bivalves in mold preservation was observed and collected. None of them have been identified yet, but it is apparent that this fauna largely differs from that collected from Unit 1.

\subsubsection{Brachiopods}

Two types of inarticulate brachiopods were commonly observed: lingulids and disciniscids. Disciniscids were relatively common throughout Unit 1, as well as in the basal gravel of Unit 2. The specimens from Unit 1 were very well preserved, those from the basal part of unit 2 showed signs of abrasion. These disciniscids belong to Discinisca. According to Dulai (2013), this genus is known from only two species in the Neogene of the North Sea Basin: D. fallens (Wood, 1872) and D. elslooensis Radwańska \& Radwański, 2003. The specimens found at AIA clearly belong to $D$. fallens.

Lingulids were only collected from the upper part of Unit 1 (layers $5 \mathrm{~b}$ and $5 \mathrm{a}$ ) and throughout Unit 2. Most existed of (fragments of) small specimens. Dulai (2013) clarified that all Belgian records of Neogene lingulids must belong to Glottidia and not to the genus Lingula, based on the presence of two divergent internal septa in the pedicle valve and a single centrally placed septum in the brachial valve. All observed lingulid material must therefore be referred to Glottidia dumortieri (Nyst, 1843).

Articulate brachiopods such as terebratulids were observed just above the basal gravel in the southernmost trough of Unit 2, both loose in the sediment as well within the friable sandstone. Within layer X, well-preserved Cryptopora nysti (Davidson, 1874) (det. A. Dulai) were very abundant. The most diverse articulate brachiopod fauna was found in layer $5 \mathrm{~b}$, with larger terebratulids possibly related to Terebratula and/or Pliothyrina occurring next to smaller Terebratulina. 


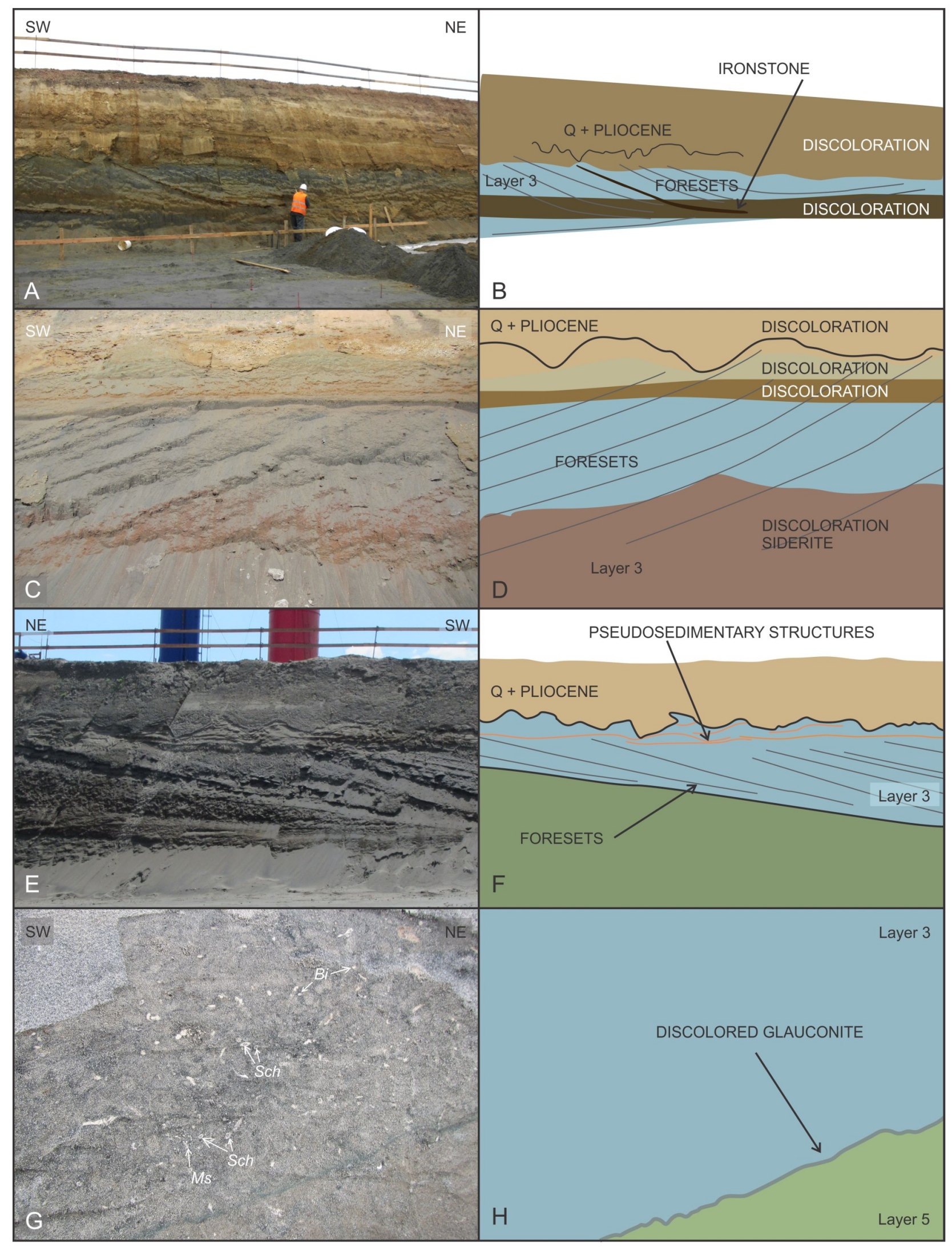

Figure 13. Observations at AIA outcrop (part 11). Pseudo-sedimentary structures resulting from post-depositional weathering, and trace fossils. AB. Brown staining of both the Quaternary and Pliocene sediments as well as the upper part of layer 3. The color of the brown sta ining is different from that of the discoloration observed in the middle of layer 3. Within this lower band of discoloration, one of the foreset beds in the southern part of the trough is cemented into a friable ironstone (LP2, middle part, W wall). C-D. Discolorations in the upper part of layer 3 just below the Pliocene deposits resulting in a subhorizontal staining and pseudo-layering in the uppermost part of layer 3 . The original inclined foreset bedding was still partly recognizable by means of the trace fossils. The lower part of the photo shows the middle part of the trough, which is reddish stained by siderite. This staining is more irregularly distributed, and only partly connected to the layering of the foresets (LP1, southern part, W wall). E-F. Weathering creating an apparent subhorizontal layering in the upper part of the foresets of layer 3, which can easily be mistaken for the presence of an additional layer of subhorizontally deposited sand on top of the layer 3 foresets. Also here, trace fossils helped to identify the original inclined foreset beds (LP1, southern part, E wall). G-H. Thin layer of bluish-green discolored glauconite at the erosive contact between Unit 1 and Unit 2 (LP1, southernmost part, W wall), Bi - Bichordites, Sch - Schaubcylindrichnus (smaller form), Ms - Macaronichnus segregatis. 

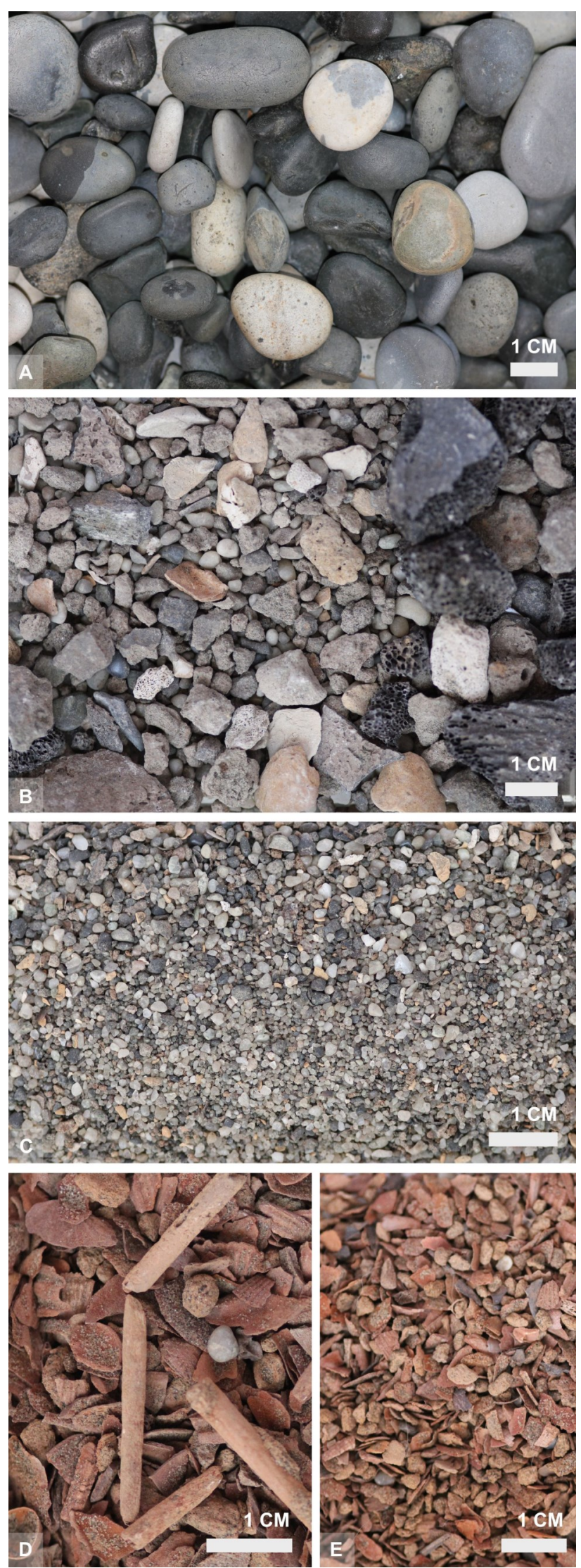

Figure 14. Photographs of coarse fractions obtained from largescale sieving operations at AIA. A. Fraction $>10 \mathrm{~mm}$ from the basal gravel of Unit 1 (base layer $5 \mathrm{c}$ ), with several different types of flint pebbles. B-C. Fractions $>2 \mathrm{~mm}$ (B) and $0.5-2 \mathrm{~mm}(\mathrm{C})$ of the basal gravel of Unit 2. D-E. Fractions between 5 and $4 \mathrm{~mm}$ (D) and between 4 and $2 \mathrm{~mm}(\mathrm{E})$ of the Mimachlamys angelonii levels within layer $5 \mathrm{~b}$, with reddish-stained fragments of pectinids, echinoid spines (D), disciniscid brachiopods (D), fish bones (D, E), whitish-gray stained quartz grains $(\mathrm{D}, \mathrm{E})$ and a large number of small clayey concretions $(\mathrm{D}$, E).
4.1.4. Bryozoans, echinoids, crustaceans, polychaetes and foraminifera

Bryozoans were only recovered from the basal part of Unit 2 in the southernmost trough of LP1 (i.e. layer $4 \mathrm{~b}$ ), both as friable colonies in possible life position loose in the sand or within sandstone (Fig. 12C), or as abraded fragments in the sandstone and residues of the basal part of Unit 2.

Echinoids were documented by reddish-stained fragments of large spines in the sieving residues of the pectinid beds of layer 5b (Fig. 14D) and reddish-stained fragments of their test in layer $\mathrm{X}$, as well as complete individuals of both irregular and regular echinoids from the basal part of Unit 2 in the southernmost trough of LP1 and locally also in layers 4 and 3 in other troughs.

Crustaceans were found in the sieving residues of layer X; some reddish-stained barnacles (Thoracica) and fragments of pincers of decapod crabs. Within Unit 2, albeit rarely, also better-preserved shields and claws of decapod crustaceans were found.

None of the observed and collected bryozoans, echinoderms, and crustaceans have been identified to genus or species level yet.

The polychaete serpulid Ditrupa was found only rarely and in very low numbers, especially within the friable sandstone in the southernmost trough in LP1. Scolecodonts were found in relatively large numbers in the sieving residues of layer $5 \mathrm{a}, 4$ and $4 \mathrm{~b}$.

Foraminifera have not yet been studied in detail. Nonetheless, several large specimens were found in the fine fractions $(0.5-1 \mathrm{~mm})$ of the sieving residues of layers $5 \mathrm{~b}, 4 \mathrm{~b}$ and $\mathrm{X}$. None of the observed and collected specimens looked 100\% pristine, nor were they indicative for a biozone or a specific environment (Thierry Moorkens \& Fritz von der Hocht, pers. commun.).

\subsection{Vertebrate fauna}

\subsubsection{Chondrichthyans}

Chondrichthyan remains were relatively abundant at AIA, and extensive collecting efforts were undertaken to fully document their diversity and assemblages in the different layers of the Diest Formation. At the writing of this paper, not all the collected material and collections were fully assessed, nor were all residues sorted through or all taxonomical issues resolved. The preliminary reports and listing of species per layer of Hoedemakers \& Dufraing (2015) are thus incomplete and will need (future) updates. As an example, additional bulk sampling $\left(60 \mathrm{~m}^{3}\right)$ by ERB and additional collecting efforts by DCG at the base of layer $5 \mathrm{c}$ yielded for instance additional genera such as the sandtiger shark Carcharias, the hammerhead shark Sphyrna, the serrated (or Escher's) mako shark Carcharomodus and the chimaera Edaphodon which had not been not recorded from this layer in the preliminary report. Moreover, the taxonomical data were not accompanied by data on abundance or preservation, warranted for a thorough statistical analyses. The latter would be of prime importance as it turned out that the chondrichthyan fauna from AIA is the by far most species-rich assemblage of the upper Miocene of the North Sea Basin known to date (Hoedemakers \& Dufraing, 2015; this paper), comprising at least 39 taxa of sharks (25), rays (11) and chimaeras (3) (data from Hoedemakers \& Dufraing, 2015). Also, several of the collected taxa had never been reported before from the upper Miocene of Belgium, nor from the Miocene of the North Sea Basin as a whole (compare with e.g. Bosselaers et al., 2004; Mollen, 2010, appendix 1; Bor et al., 2012; Everaert et al., 2019).

Chondrichthyan remains were found in all layers of Units 1 and 2, except for layer 6 . The highest concentration of 
chondrichthyan remains per volume of sediment was found in layers $\mathrm{X}, 4 \mathrm{~b}$ and 4 , the lowest concentration in layer 3 , and layer $5 \mathrm{c}$ had a somewhat higher number of collected material than layer 5 b.

The chondrichthyan remains existed exclusively of isolated teeth, except for a few rare and large isolated vertebrae found in layers 5,4 and $\mathrm{X}$. The preservation of the teeth displayed the whole spectrum from immaculate with pristine roots and enamel (most of the collected specimens) to abraded enamel fragments down to phosphatic rods. Specimens showing extensive signs of reworking were found in relatively low number at the base of layer $5 \mathrm{c}$ and $X$, and in much higher numbers in layers 4 and $4 \mathrm{~b}$. Amongst the very abraded specimens of layer 4, some Eocene abraded shark teeth also occurred. Some of the material found at the base of 5c (e.g. Carcharoides catticus (Phillippi, 1846) in ERB collection) may have been reworked from the underlying Antwerpen Sand Member. A peculiar mode of preservation with shark teeth missing their root but still having rather pristine enamel occurred in layers 5c, 5b, 5a, 4 and X.

None of the faunas of the individual layers $(5 c, 5 b-5 a, 4,3)$ have an identical composition or diversity. Within Unit 1 , layer $5 \mathrm{c}$ is rich in large predatory sharks of the orders Lamniformes (i.e. Otodus, Cosmopolitodus, Carcharomodus, Isurus, Lamna), Carcharhiniformes (i.e. Carcharhinus, Galeocerdo, Sphyrna) and Hexanchiformes (i.e. Notorynchus); their modern representatives are littoral (coastal) to epipelagic sharks, that feed on a variety of large (vertebrate) prey such as (carcasses of) marine mammals, other elasmobranch and teleost fish (see Compagno, 1984). Modern great white sharks, closely related to the common Cosmopolitodus hastalis, often swim close inshore, attracted by pinniped colonies. Where great white sharks disappear, their niche is often taken by adult sevengill sharks (Notorynchus) (Hammerschlag et al., 2019). Recent tiger shark Galeocerdo also preys on turtles and large seabirds (see e.g. Witzell, 1987; Lowe et al., 1996; Heithaus, 2001). Fossil remains of all prey listed here are abundantly present in layer $5 \mathrm{c}$. By contrast, among the large predatory sharks, layer $5 \mathrm{~b}$ only yields rare teeth of Cosmopolitodus hastalis, and a single tooth of Isurus retroflexus (Agassiz, 1843) (coll. Jef De Ceuster). Although much rarer, layer $5 \mathrm{c}$ also yielded teeth of other epipelagic genera, such as Alopias (thresher sharks) and Mobula (devil rays). These taxa also frequent the open ocean, in search of small fish such as sardines/anchovies and planktonic organisms respectively. These elasmobranch species are not present in layer $5 \mathrm{~b}$ either. In large contrast to layer $5 \mathrm{c}$, layer $5 \mathrm{~b}$ yields a lot of smaller, often demersal and benthic species, including catsharks (Scyliorhinus spp.), smooth-hounds (Mustelus sp.) and many skates and rays, that are positioned a little lower in the food chain, and whose modern representatives even occur close inshore (i.e. sub/littoral, not oceanic), feeding on a wide variety of small invertebrate organisms and teleost fish living on or near the sea bottom. Fossil remains of such prey are commonly present in layer $5 \mathrm{c}$. Catsharks, skates and chimaeras are oviparous (Musick \& Ellis, 2005); they deposit and attach their eggs on the seabed or near the bottom at macroalgae, coral, etc. that require particular substrates depending on the species needs (see e.g. Pretorius \& Griffiths, 2013)

Within Unit 2, there is a major difference in the alpha diversity between layer 4 and 3 ( 31 vs. 8 to 9 species). As seen in Unit 1 , the contrast between layer 4 (many large predatory, epipelagic sharks) and layer 3 (smaller demersal and benthic species) is significant. The possible presence of Prionace glauca (Linnaeus, 1758), the modern blue shark, a typical oceanicepipelagic shark, in layer 4 (Hoedemakers \& Dufraing, 2015), validates this contrast with layer 3 even more.

Remarkably, between Unit 1 and Unit 2 as a whole, no significant differences were found. In fact, the differences within Units 1 and 2 respectively, are more significant than between Units 1 and 2 as a whole. The species diversity in layer $5 \mathrm{c}$ is quite similar to that of layer 4 , whereas the species diversity in layer $5 b$ is quite similar to that of layer 3 (many smaller, demersal sharks, skates, and rays).

In addition, when the faunal listings of Hoedemakers \& Dufraing (2015) are compared with those of the Antwerpen Sand Member (Bor et al., 2012), it is remarkable that the fauna of layer $5 \mathrm{c}$ reveals a large similarity with the chondrichthyan fauna of the Antwerpen Sand, as does the fauna of layer 4. This similarity drops significantly in layer $5 \mathrm{~b}$ and layer 3 .

In conclusion, the fluctuating availability of specific prey (large vertebrates vs. smaller invertebrates) seems to have played a significant role in the elasmobranch diversity recorded in subsequent layers of the Diest Formation. As a result, paleoenvironmental conclusions based on elasmobranch fish alone are rather indirect. In addition, the occurrence of some species might also be the result of evolutionary trends during the Miocene rather than reflecting paleo-environmental differences. Shark genera that originated in the Paleogene, such as the basking shark Keasius and the catshark Pachyscyllium, became extinct in the North Sea Basin towards the upper Miocene (see Reinecke et al., 2015; Collareta et al., 2020), which might explain their presence/absence in Units 1 and 2 respectively. This might be the other way around for 'new' species whose origin is situated in the (upper) Miocene.

\subsubsection{Teleost fishes}

Amongst the larger remains, an impressive find of a huge and very well-preserved dermal nose plate with adjacent plates of a Molidae (sunfish) was found in layer 5c (coll. Jef De Ceuster). Several jaws of juvenile Molidae were found in the lower part of $5 \mathrm{c}$ and a single jaw of an adult specimen was found ex situ (presumably layer 5, unspecified; coll. Luc Anthonis). Dermal plates of sturgeon (Acipenser sp.) were not uncommon in layer $5 \mathrm{~b}$.

Amongst the smaller remains, no teleost fish otoliths, so abundant in other Miocene sediments of the North Sea Basin, were discovered, most probably due to the post-depositional decalcification of the sediments. Isolated osteological remains of teleosts, however, were frequently found in the sieving residues (size fraction above $0.5 \mathrm{~mm}$ ) of layers $5 \mathrm{c}, 5 \mathrm{~b}, 4$ and 3 , but no detailed study has been published yet, so only generalized remarks can be given here. Most of these remains pertain to unidentifiable vertebrae and other bones, but some could already be identified at least to family level. All throughout layer 5, vomers, premaxillae, and parasphenoids of Gadidae could be encountered, similar to those described and figured by Wienrich (2009, p. 1052 and following). Jaw fragments referable to Lophiidae were also present. Moreover, otic bullae of Clupeidae, perhaps belonging to the genus Sardina, were common (see Wienrich, 2009, plate 204, and Hoedemakers \& Dufraing, 2015, plate 1.4). These faunal elements are very similar, if not identical, with those encountered in older Miocene deposits of the North Sea Basin (Wienrich, 2009; Hoedemakers \& Dufraing, 2018; and unpublished data for the Antwerpen Sand Member). A more detailed study on the clupeid otic bullae is in preparation. In addition, layer 4 especially contained reworked material, and layer 3 yielded only unidentifiable osteological remains of teleosts.

\subsubsection{Marine mammals}

An anomalously high concentration of marine mammal remains, including Mysticeti (baleen whales), Odontoceti (toothed whales), and, to a lesser extent, Pinnipedia (seals) occurred in 
the lower parts of Unit 1 (layer 5c), especially between 50 and $150 \mathrm{~cm}$ above the base of Unit 1 . Their remains consisted both of isolated skeletal elements up to nearly complete skeletons with skulls and vertebrae in anatomical connection. This high abundance in layer $5 \mathrm{c}$ contrasted sharply with the very low number of their remains in layers $5 \mathrm{~b}, 5 \mathrm{a}$ and 3 . Cetacean fossils were again higher in number at the base of Unit 2, in layer 4, but then almost solely consisting of abraded and eroded bone fragments. An incredibly large accumulation of bones was found at the bottom of the deepest Unit 2 trough just north of the tunnel entrance in LP2 ('layer X'), with all the bones showing signs of abrasion.

The cetacean remains were generally strongly decalcified and poorly mineralized. The quality of the fossils varied a lot, some of them being very well preserved, isolated, rather complete articulated neurocrania, whereas others were strongly eroded skeletons, somewhat distorted, but nevertheless preserved in anatomical connection. Well-preserved skeletons must have been deposited in a quiet environment favorable to fossilization; they were most likely covered by sediment shortly after deposition of the carcass. Some specimens, including mysticetes and one small physeterid, showed multiple shark bite marks, either indicating predation events (e.g. Alfsen et al., in press) or scavenging on a floating or deposited carcass. The latter case would suggest a relatively long time of exposure of the cetacean remains on the seafloor before being covered with sediment. However, no encrustations of for instance barnacle shells were observed on bones.

A rich mysticete fauna is recorded from Unit 1 (especially from layer 5c), representing at least seven different small whale species. The partial neurocranium of a very young specimen of aff. Parietobalaena sp. was discovered; it includes the vertex, a periotic and a tympanic bulla (coll. Jef De Ceuster: layer 5c). A partial skeleton referred to 'Parietobalaena' affinis (sensu Steeman, 2010) exists of a rather complete neurocranium with the vertex (frontal), a periotic, a tympanic bulla, cervical and thoracic vertebrae, ribs, a scapula, a partial forelimb, and a partial mandible (coll. Jef De Ceuster: layer 5c). Several other finds belong to at least three morphotypes (species) of Herentalia-like cetotheriids (Bisconti, 2015). Two of them are represented by rather complete neurocrania, one of which (coll. Bert Gijsen: layer 5c) is very similar (possibly conspecific) to the large skeleton found at Middelares Hospital provisionally identified as Plesiocetus sp. (Bosselaers et al., 2004). An isolated right periotic belongs to the enigmatic genus Aglaocetus (sensu Steeman, 2010) and is referred to 'A.' burtini (layer $5 \mathrm{c}$ ). Another right periotic is referred to 'Plesiocetus' dubius (sensu Van Beneden, 1885); the latter was found for the first time in anatomical connection with its squamosal (coll. Bert Gijsen: layer 5c). In situ finds of these periotic morphotypes are rare. An isolated tympanic bulla found ex situ (coll. Jef Segers) is very similar, though not identical, to the one attributed to Mesocetus pinguis by Van Beneden (1886). It could belong to either one of the late Miocene species ' $A$.' burtini, 'A.' rotundus (sensu Steeman, 2010), and ' $P$.' dubius (sensu Van Beneden, 1885), or the middle Miocene species ' $A$.' latifrons and ' $A$. longifrons, or even to a new, very rare taxon.

The odontocete fauna from Unit 1 is slightly less diverse, with members of the clades Squalondontidae (some of the last heterodont odontocetes, set of six associated teeth found at the base of layer 5c (coll. Geert De Borger \& Walter Van Remoortel) and one jaw with teeth found ex situ (coll. Bert Gijsen)), Eurhinodelphinidae (hyper-longirostrine dolphins, common in the Berchem Formation; see Lambert, 2005a), Physeteroidea (sperm whales, at least two species), Ziphiidae (beaked whales, also in Unit 2, layer 4), and several early Delphinida (relatives of dolphins and porpoises). Among those, the exquisitely preserved cranium of a small physeterid (IRSNB M.2329, ex. coll. Leo Dufraing) is referred to the poorly known genus Thalassocetus, allowing for a re-assessment of the phylogenetic affinities of the latter (Alfsen et al., in press). Two ziphiid specimens including cranial remains (coll. Bert Gijsen \& Mark Bosselaers) share many similarities with the species Ziphirostrum marginatum, previously recorded in the lower unit of the Diest Formation at Middelares hospital (Bosselaers et al., 2004; Lambert, 2005b). An isolated periotic from Unit 2, layer 4 (coll. Jef Segers) is tentatively attributed to the family Pontoporiidae, which is nowadays only represented by a single small coastal dolphin species from the southwestern Atlantic but was more diverse and broadly distributed during the late Miocene-early Pliocene (Post et al., 2017).

Several postcranial remains of phocids (true seals) were discovered in Unit 1 (coll. Bert Gijsen, Frederik Mollen \& Jef Segers), including bones referred to the diminutive phocine species Nanophoca vitulinoides (IRSNB M.2272-2275; Dewaele et al., 2017a); the close match of various hind limb, innominate, and sacrum parts suggests that at least some of these elements belong to a single individual, a condition that is relatively rare for pinnipeds from the Neogene of Antwerp (Dewaele et al., 2017a, 2017b). Additionally, a complete ectotympanic of Pinnipedia indet. was recovered from layer $5 \mathrm{c}$ (coll. Jef De Ceuster). Finally, the partial humerus of a larger phocine, tentatively attributed to the species Frisiphoca affine (see Dewaele et al., 2018), originates from Unit 2, layer 4 (coll. Mark Bosselaers; identification Leonard Dewaele).

\subsubsection{Birds, turtles and land mammals}

Extremely rare but very well-preserved remains of large birds, sometimes even with several associated bones together, one of them (coll. Bert Gijsen) provisionally identified as a relative to the Northern gannet (Wim Wouters; pers. commun.), were recovered from layer 5c. At least two rib fragments of Cheloniidae (marine turtles) were also found in layer $5 \mathrm{c}$, and one small artiodactyl astragalus (even-toed ungulate; land mammal) was collected from layer X (coll. Bert Gijsen). In situ finds of birds, turtles and land mammals in the Belgian Neogene are extremely rare (e.g. Misonne, 1958), and further add to the importance of the AIA site.

\subsection{Plants}

Small and larger pieces of partly decayed wood logs were observed throughout the entire Diest Formation sequence at AIA (Fig. 2). Some of the larger pieces were several meters in length, more than half a meter wide and more than $10 \mathrm{~cm}$ thick. Some of the observed specimens were bioturbated by wood boring bivalves, in particular the longer branches in layer $5 \mathrm{~b}$ in LP1 and several larger pieces in layer 4. Seeds and pinopsid seed cones were found in layer $5 \mathrm{~b}$, and one seed in layer $5 \mathrm{c}$ (coll. Ben D'Haeze). A remarkable observation is that some of the material preserved rather well without any treatment, while other material decayed rather quickly, hinting at the presence of at least two types of wood. In sediment sampled just next to larger pieces of wood, needle-shaped gypsum crystals, indicative of pyrite oxidation, were omnipresent.

\subsection{Trace fossils and ichnofacies}

Trace fossils were observed in smoothed vertical, oblique and horizontal surfaces, and documented by photos. One of the striking differences between Unit 1 and Unit 2 is found in these trace fossils, which give insights into the depositional environment.

\subsubsection{Trace fossils in Unit 1}

Deposits of Unit 1 are totally bioturbated, which resulted in the 
fading of many of the primary sedimentary structures. The visibility of individual burrows also changed throughout the lithological column, being less visible in the lowest part of Unit 1.

A frequently observed trace fossil is characterized by oval spots that are 40-90 $\mathrm{mm}$ wide and 35-70 $\mathrm{mm}$ high and show a non-uniform filling, usually with darker and finer grains towards the margins (Fig. 5C). In oblique cross section, they show a crude, asymmetric meniscate filling (Fig. 6H). These burrows are cross sections of Scolicia (cf. Asgaard \& Bromley, 2007), which is a feeding and locomotion burrow produced by irregular echinoids of the Spatangus group (Uchman, 1995 and references therein).

Another class of burrows is represented by oval spots and horizontal or oblique bars, $13-18 \mathrm{~mm}$ wide, lighter than the surrounding sediment (Figs 5C, G, H \& 6A), and with some lateral extensions (branches?). Their filling is uniform, bipartite, or with some eccentric, incomplete rings, which differ in color shade. They probably are sections of Thalassinoides, a dwelling and feeding burrow system produced mostly by crustaceans, foremost decapods (e.g., Ekdale, 1992; Neto de Carvalho et al., 2007).

Spots up to $10-15 \mathrm{~mm}$ wide show a shape of a reversed triangle. In rare cases, they occur in the center of larger, elliptical spots (Fig. 5C, H). The triangular spots may be cross sections of the central core of Bichordites and the surrounding oval spots can be outlines of the remaining part of the burrow in cross section. Bichordites is a locomotion and feeding burrow of irregular echinoids belonging to the Echinocardium groups (e.g. Uchman, 1995) and by some spatangoids (Bernardi et al., 2010).

Rectilinear, or slightly curved, subvertical or oblique, rarely subhorizontal tubes, lined with muddy/silty material belong to Ophiomorpha (Figs 5C \& 6B, F), a dwelling and feeding burrow produced by decapod crustaceans, resembling those of the extant Callichiurus major (see Frey et al., 1978, 1984). They cut the remaining elements of the ichnofabrics and can be traced downwards for $50-70 \mathrm{~cm}$.

Smaller and variably-oriented straight or curved spots and bars, 3-6 $\mathrm{mm}$ in diameter, mostly lighter than the surrounding sediment, are ascribed to Planolites (Fig. 6A), a locomotion and feeding burrow produced a large variety of invertebrates, foremost "worms" (e.g., Pemberton \& Frey, 1982; Keighley \& Pickerill, 1995).

Very rarely, subhorizontal, winding, subcylindrical, faintly meniscate burrows, up to $20 \mathrm{~mm}$ wide are visible (Fig. 6B). They are determined as Taenidium, a locomotion and feeding burrow produced by variable types of invertebrates (e.g., Keighley \& Pickerill, 1994).

\subsubsection{Trace fossils in Unit 2}

The trace fossils of the Unit 2 are more distinct, and the sediment is only party bioturbated. Most of the trace fossils are distributed along the foreset laminae, which are partially preserved or obliterated by bioturbation. In the latter case, the ichnofabrics follow the primary sedimentary structures.

Macaronichnus is a variably oriented, curved to winding, rarely looping cylindrical burrow composed of a light core and surrounded by a darker, ca. $1 \mathrm{~mm}$ thick mantle which is mostly composed of glauconite grains. Two size classes occur, one with a diameter between 1-2 mm (Figs 6F, 11B-H, 10C-D \& 13G) and a second with a diameter between $3-5 \mathrm{~mm}$ (Figs $6 \mathrm{~F}, 11 \mathrm{~B}, \mathrm{D}$ $-\mathrm{H} \& 10 \mathrm{C}-\mathrm{D})$. The burrows of the larger class may show some swellings and constrictions and are assigned to Macaronichnus segregatis degiberti Rodríguez-Tovar \& Aguirre, 2014. The ones of the smaller class are assigned to Macaronichnus segregatis Clifton \& Thompson, 1978. Commonly, both ichnospecies occur in patches. Macaronichnus is a feeding and locomotion burrow of polychaetes, which segregate grains (e.g.,
Clifton \& Thompson, 1978; Nara \& Seike, 2019).

Schaubcylindrichnus is a mostly oblique tubular burrow showing a thick (1-4 mm) light wall and a dark filling which is 7-10 $\mathrm{mm}$ in diameter (Fig. 10D). In smaller specimens, the filling is only $5 \mathrm{~mm}$ and the wall only $1 \mathrm{~mm}$ thick (Fig. 13G). These are dwelling and feeding burrows of enteropneusts or polychaetes (Löwemark \& Nara, 2010).

Scolicia is visible as oval spots, $60-75 \mathrm{~mm}$ wide and $50-60$ $\mathrm{mm}$ high (Fig. 11B-C). Some of them show a convex up base. Glauconite pellets are concentrated in the middle, and lighter colored grains close to the margin.

Thickly lined tubes that are $25 \mathrm{~mm}$ wide are much rarer observed and assigned to Ophiomorpha (Fig. 11C, G-H). In addition, indistinct Bichordites trace fossils are visible in places (Fig. 13G).

In some of the foresets, Scolicia is much more common than Macaronichnus, but in others, it is the other way around (Fig. 11B-C). In the crosscutting relationships, M. s. degiberti and $M$. segregatis obviously crosscuts Scolicia, and M. s. degiberti and $M$. segregatis crosscut each other.

\subsubsection{Interpretation of ichnofacies}

The trace fossil assemblage of Unit 1 (Thalassinoides, Planolites, Scolicia, Bichordites, Ophiomorpha, Taenidium) can be ascribed to the Cruziana ichnofacies, which typically occurs in the shoreface-offshore zone (e.g., Pemberton et al., 2001; MacEachern et al., 2012). The total bioturbation of Unit 1 suggests a low energy setting, in which storm-related sedimentary structures would not become preserved. This is possible in the lower offshore, where usually thin storm beds can be totally bioturbated. However, finer-grained deposits would be expected in this zone. Moreover, the presence of Ophiomorpha suggests a shallower zone as it is more typical in the proximal variant of the Cruziana ichnofacies. A highly protected environment can also be considered, but a higher percentage of the fines $(<125 \mu \mathrm{m})$ would then be expected. In addition, the presence of the echinoid burrows Scolicia and Bichordites proves that normal salinity conditions prevailed, while in a highly protected environment, salinity conditions can be abnormal. In conclusion, the trace fossils indicate that Unit 1 was deposited in the shoreface of a semi-protected shelf setting, with fully marine conditions, very low sediment accumulation rates, a low and insignificant intensity of storms, where the sediment was rich in food. This conditioned a high bioturbation intensity which caused complete obliteration of sedimentary structures. The abundance of glauconite and fossils, common when sedimentation rates are low, supports this view.

The trace fossil assemblage of Unit 2 (M. s. degiberti, M. segregatis, Schaubcylindrichnus, Scolicia, Ophiomorpha, Bichordites) can be also ascribed to the Cruziana ichnofacies, but to its higher energetic variant, where the primary sedimentary structures are partially preserved. This change does not necessarily imply a significant bathymetric change when compared to Unit 1. Macaronichnus s. degiberti occurs at different depths ranging from the intertidal zone, across the shoreface to deeper but well-oxygenated and food-rich environments (Seike et al., 2011; Rodríguez-Tovar \& Aguirre, 2014; Nara \& Seike, 2019). The presence of the smaller $M$. segregatis, which is abundantly known from upper foreshore environments but can also occur in shoreface settings (Bromley et al., 2009), does not contradict this interpretation. Schaubcylindrichnus occurs in shelf and slope deposits but it is most common in the lower shoreface and upper offshore (Frey \& Pemberton, 1991; Löwemark \& Nara, 2010). Very similar Schaubcylindrichnus to the larger one from Unit 2 occurs in the Lower Cretaceous Arnager Greensand Formation near Rønne, Bornholm, Denmark which was interpreted as a storm 
dominated shoreface by Knaust (2017; figs 5.128c, d).

The Unit 2 records slow migration of the bedforms responsible for the foresets. Colonization of the bedforms occurred when their migration was very limited or temporarily paused (Pollard et al., 1993; Uchman et al., 2020). In such conditions, packages of bioturbated and non-bioturbated foresets alternate. At AIA, almost every foreset is bioturbated, which indicates very slow migration of the bedforms, in which the accreting slopes were invaded by burrowing echinoids producing Scolicia, followed by a colonization of polychaetes producing Macaronichnus. If migration of the bedforms had been faster, non-bioturbated packages of foresets would have prevailed, which is clearly not the case at AIA (see Colella \& D'Alessandro, 1988).

\section{Analytical results}

\subsection{Granulometry \& glauconite content}

The results of the lab analysis of the granulometry and glauconite content are summarized in Figure 15, plotting the granulometry, the individual grain-size frequency distribution curves and the glauconite content onto the AIA composite section and in Figure 16, plotting the mean, median, mode, skewness and kurtosis on stratigraphically ordered scatter graphs. These allow to identify similarities and differences between the layers and units, as well as important trends within and throughout them.

One of the main similarities all AIA samples have in common is the heterogenous character of the grain size, which can be read both from the shape of the individual frequency distributions, the granulometry curve, the differences between the mean and the mode and median, and the skewness and kurtoses.

Three different types of grain-size frequency curves can be identified within the Diest Formation: 1) those with only a single broad and low peak that also have a large skewed tail in the coarse sand domain, 2) those with two peaks, a first welldefined one with a mode in the fine sand domain $(128-250 \mu \mathrm{m})$ and a second much smaller one with a fairly constant mode in the coarse domain and 3) those with a single well-defined peak, much alike the former type, but in which the second peak or a tail in the coarse domain are completely absent.

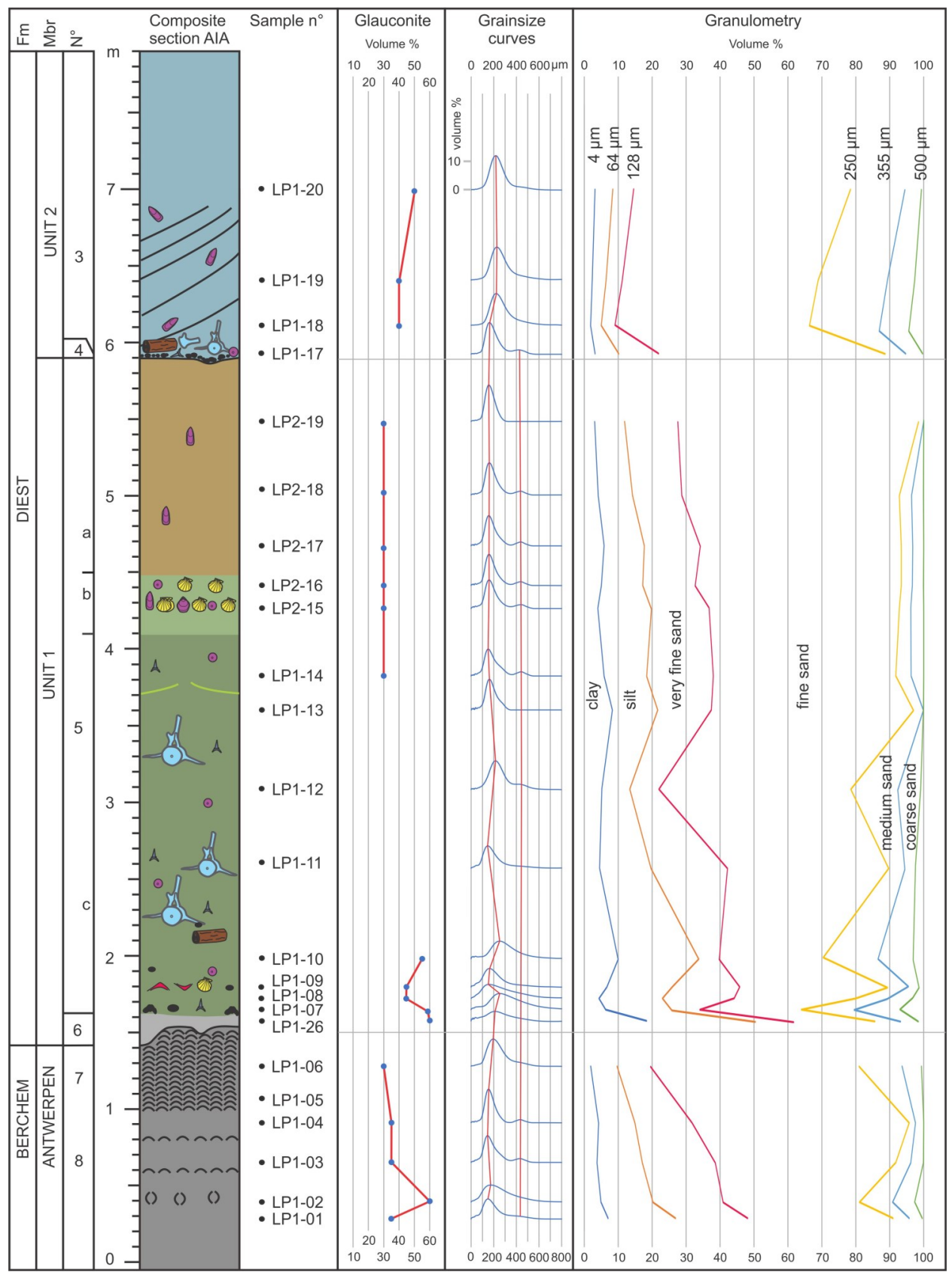

Figure 15. Glauconite content, grain-size frequency distribution curves and granulometry plotted against a (hypothetical) AIA composite. 
These three types have a different stratigraphic occurrence; the first is restricted to the lowest meter of Unit 1, the second to the middle and upper parts of Unit 1 as well as the entire Unit 2, and the third to a small number of samples of the middle and upper parts of Unit 1 (LP1-13; LP1-19). These types also grade into each other; type 1 gradually grades into types 2 and 3, and within type 2 , there is also a trend towards narrower and betterdefined peaks. The three types also clearly represent different grades of sorting, in which grade 1 represents the lowest grade; type 1 samples combine high amounts of clay-silt-very fine sand with a relatively large important coarse fraction.

Fine sand represents the by far largest fraction of the grain size in all but one of the Diest Formation samples (LP1-26, layer 6). Except for the lowest meter of Unit 1, in which the fine fraction content rapidly rises from $24 \%$ (LP1-26) to $47 \%$ (LP111), the fine fraction content varies between 54 and $70 \%$ in all of the samples. Medium and coarse sand fractions are highest in the lowest $2 \mathrm{~m}$ of Unit 1 and in Unit 2, and low within the upper part of layer $5 \mathrm{c}$ and the entire layers $5 \mathrm{~b}$ and $5 \mathrm{a}$. The clay-siltvery fine sand fraction allows for a clear separation between Unit 1 and Unit 2, with the fines taking more than double the amount in Unit 1 than in Unit 2.

The different evolutions in the fractions and grain sizes are also well expressed in the changes of the mode, median, mean, skewness and kurtosis. Again, these parameters allow to clearly separate Unit 1 from Unit 2. In addition, the relative unstable settings of the lower part of Unit 1 is well expressed in the large difference between the mode and the median, a difference that largely recedes in the upper part of layer $5 \mathrm{c}$ and higher upsection.

The glauconite content also differs between Unit 1 and Unit 2. Except for the basal part wherein very high contents of 45 to $60 \%$ were measured, glauconite content is at a stable $30 \%$ throughout Unit 1 and between 40 and 50\% in Unit 2. The thin sections also revealed that the very base of Unit 1 (LP1-26 up to LP1-08) is characterized by the presence of large glauconite grains.

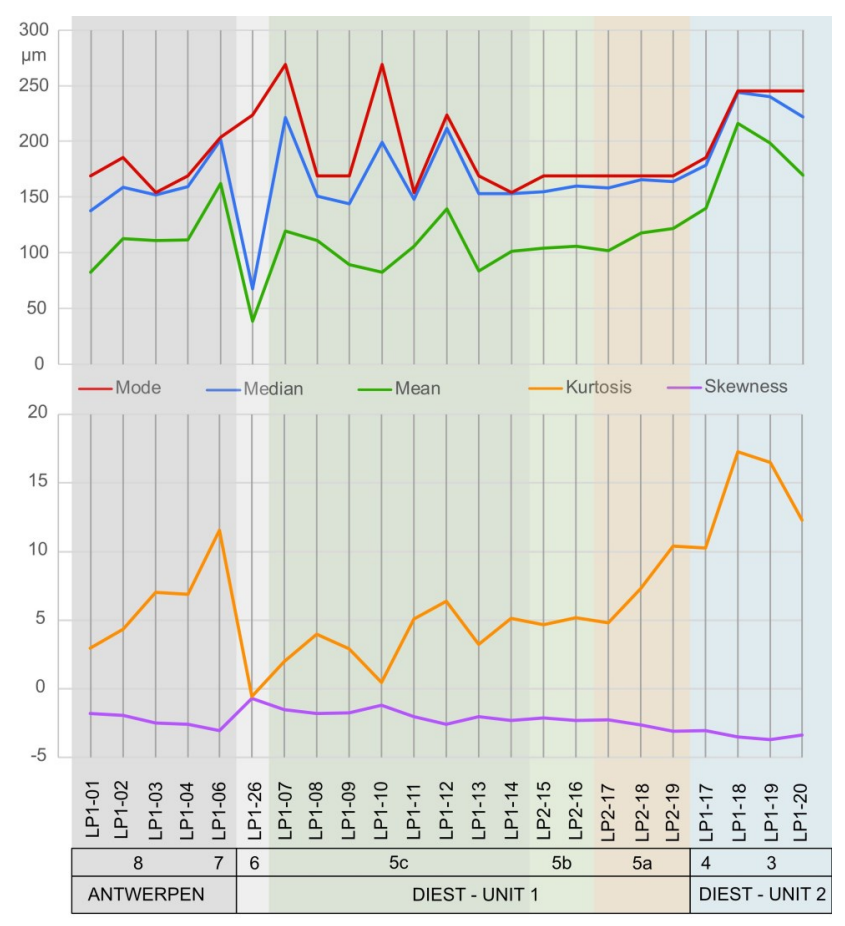

Figure 16. Mode, median, mean, kurtosis and skewness plotted on stratigraphically ordered scatter plots.
Summed up, the lab analyses of the granulometry and glauconite content further document the major differences between Unit 1 and Unit 2. Moreover, quite strikingly, Unit 1 and the underlying Antwerpen Sand are much alike in many of the parameters.

\subsection{Clay mineralogy}

Adriaens (2015) analyzed three samples from Unit 2 of LP1 of the AIA outcrop (Fig. 17). The samples were taken at 10, 40 and $150 \mathrm{~cm}$ above the base of the unit, and labelled RU208, RU209 and RU210, respectively. Whereas the former two samples were collected in an intensively bioturbated section, the latter was collected in the foresets of a section with dominant cross stratification and less bioturbation. These results were also incorporated in Adriaens \& Vandenberghe (2020, this volume).

The bulk mineralogical composition of the size fraction below $32 \mu \mathrm{m}$ consisted mainly of 2:1 Al-clays (24-36\%) and $2: 1$ Fe-clays (including glauconite minerals) (27-45\%), and much lower amounts of chlorite and kaolinite. Within the carbonates, calcite, aragonite, and traces of siderite were recognized. Adriaens (2015) reported that sample RU209 revealed particularly large amounts of gypsum (18\%) and pyrite (8\%), which most probably resulted from a fragment of decaying fossil wood contaminating the sample.

The mineralogical composition of the size fraction below 2 $\mu \mathrm{m}$ consisted mainly of smectite (35-37\%) and interstratified illite/smectite (38\%), next to less abundant illite (12-14\%) and kaolinite $(7-8 \%)$. From chlorite, only traces were measured. Interstratified glauconite/smectite takes about 4-5\%. In RU210, glauconite/smectite was much more abundant $(25 \%)$.

Four additional samples were analyzed with XRD, three from Unit 1 (LP1-11, LP1-12, LP1-13), and one from Unit 2 (LP1-19) (see also Appendix 1). The diffractograms of those four samples are almost identical, meaning that the clay mineralogy of Unit 1 and Unit 2 must be very similar.

In general, the mineralogical composition of the fraction below $2 \mu \mathrm{m}$ mimics that of the Berchem Formation and most of the Diest Formation known from other sites, but contrasts sharply with the generally glauconite/smectite dominated clay mineralogy of the Diest sand member in the Campine area (Adriaens \& Vandenberghe, 2020, this volume). The latter can be an effect of the fairly coarsely grained Kempen Diest sand, which was deposited in higher energy settings, blocking detrital marine clays (smectite, illite/smectite) from being deposited, so that the remaining amounts of clay primarily originated from abraded pelletal glauconite.

Adriaens (2015) also measured the (pelletal) glauconite content by magnetic separation, resulting in very similar estimates as those obtained from thin sections, of respectively 46\% (RU208), 39\% (RU209) and 40\% (RU210).

\subsection{Fe-content and ferric/ferrous ratio}

$\mathrm{Fe}^{2+}, \mathrm{Fe}^{3+}$ and $\mathrm{Fe}$ total concentrations were measured along the main section of LP1, as well as along two additional sections within layers $5 \mathrm{~b}$ and $5 \mathrm{a}$ (Fig. 18). Fe concentrations per sample varied from 64.7 up to $101.7 \mathrm{mg} / \mathrm{g}$ and were highest and lowest near the base and top of Unit 1 respectively. A generally decreasing trend occurs throughout the Diest Formation, with one reset point to slightly higher values near the base of Unit 2 . The trends in the main section seem to (roughly) follow that of the glauconite content, but the somewhat different numbers combined with the slightly different trends in the two additional sections indicate that other factors must have played an important role determining the Fe content of the samples. No clear link was found to the field observed changes in weathering, nor to the visual inspection of the weathering of the glauconite in the thin sections. 

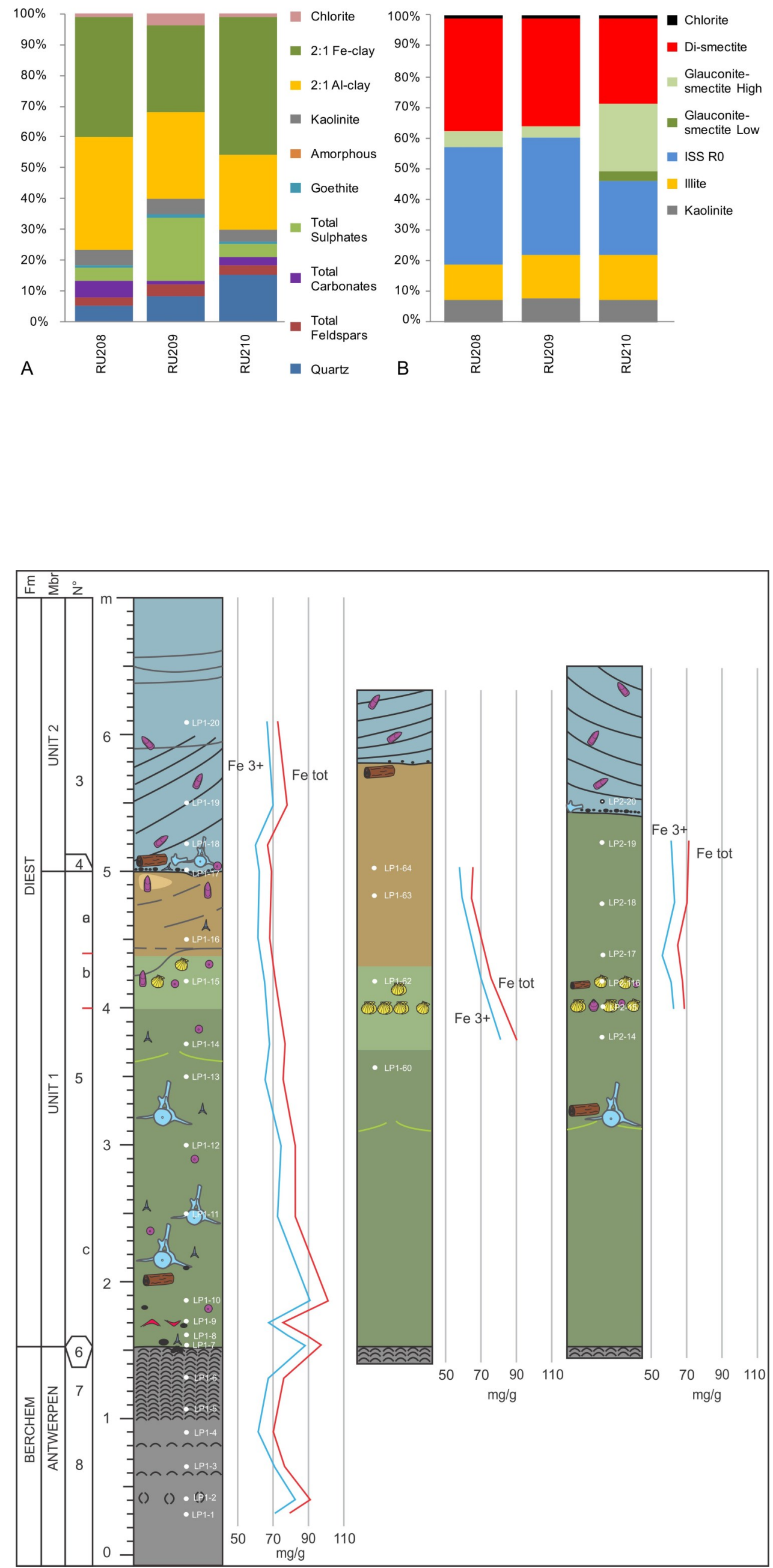

Figure 17. Bulk mineralogical composition of the fraction below $32 \mu \mathrm{m}$ (A) and below 2 $\mu \mathrm{m}$ (B). After Adriaens (2015, figs 5.10-5.11), modified.
Figure 18. $\mathrm{Fe}$ and $\mathrm{Fe}^{3+}$ contents plotted onto the AIA stratigraphy. 
In addition, all the analyzed samples had a constant $\mathrm{Fe}^{3+} /$ $\mathrm{Fe}^{2+}$ ratio, revealing that $88 \pm 2 \%$ of the $\mathrm{Fe}$ of both the Berchem and Diest Formations at AIA finds itself in an oxidized state, regardless of the amount of $\mathrm{Fe}$ present in the sample. Adriaens et al. (2014), investigating the chemical composition of pelletal glauconite, reported exactly the same ferric/ferrous ratio in nearly all important glauconite occurrences in the Cenozoic of the southern North Sea basin.

\section{Reinterpretation of the Middelares temporary outcrop}

The Middelares section is the only other expanded Diest Formation outcrop at Antwerp described in literature, 1.80 to $2.40 \mathrm{~km} \mathrm{NE}$ of AIA. A restudy of a surviving sample set and photographs, and observations made by the first author back in 2001 combined with the observations at AIA, now allow for a complete reinterpretation of the section as described by Bosselaers et al. (2004) (Fig. 19). Quite strikingly, the Middelares and AIA sections are very similar, and the twofold division that was identified at AIA can also be recognized at Middelares.

The most striking similarities between Middelares and AIA are:

1) the nearly identical total thickness of the Diest Formation interval: $5.6 \mathrm{~m}$ versus $5.5 \mathrm{~m}$;

2) the presence of an upper and lower lithological unit of heterogenous glauconiferous quartz sand, characterized by the same differences in color, appearance, structure, ichnofabric and macrofaunal associations;

3) the nearly identical lithological characterization of both units at both sites;

4) the same presence of a restricted interval in which the pectinids Mimachlamys angelonii and Pseudamusium inflexum occur, named 'level f' or 'Mimachlamys angelonii level' by Bosselaers et al. (2004) and layer 5b (this paper);

5 ) the nearly identical vertical position within the succession of the latter pectinid interval; $3.00 \mathrm{~m}$ and 2.50 to $2.85 \mathrm{~m}$ respectively;

6) the presence of dispersed gravel and phosphate nodules at the base of the section.

The main dissimilarities with AIA are:

1) a much higher number of calcareous fossils in the upper unit, with plenty of bryozoans, small bivalves and gastropods, echinoids, crustaceans, Ditrupa, other fossils. This possibly is the result of a lower degree of decalcification with the deposits being better protected from decalcification by the more clayey nature of the Pliocene crag that lies on top of the Miocene succession. Alternatively, this may simply represent the better preservation of the bryozoan reef remains and its inhabitants at time of burial;

2) the absence of large trough structures in the upper unit. This is most probably just an artifact of the vertically drilled concrete walls in the outcrop, hampering the observations of large sedimentary structures. The presence of alternating 'bands' characterized by fluctuation in abundance of bioturbation structures with a clear separation between quartz and glauconite are very distinct indicators of the presence of foresets and troughs similar to AIA;

3) the absence of a basal gravel as well as friable sandstone within the basal meter of the upper unit. Possibly, this is another result of the outcrop conditions, not allowing detailed observations of the transition between the lower and upper units; some of the descriptions of 'level e' of Bosselaers et al. (2004) may hint at their presence.

4) the abundance of skeletal remains and partial skeletons of marine mammals in the upper part of the lower unit. At AIA, only isolated remains like vertebrae of marine mammals were

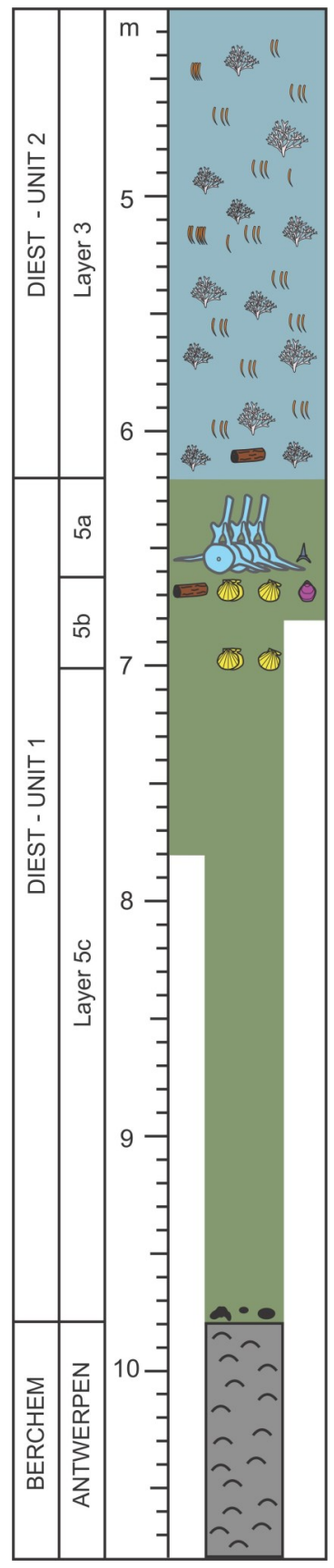

Figure 19. Reinterpretation of the original lithological succession of the Middelares section of Bosselaers et al. (2004), now coded with the same numbering of layers and units as used in the AIA section in Fig. 2. discovered in layers $5 \mathrm{~b}$ and $5 \mathrm{a}$. It is possible that the erosion of layer 5a in large parts of the AIA outcrop as well as the absence of large subhorizontal cuts in layers $5 \mathrm{~b}$ and $5 \mathrm{a}$ at AIA are responsible for this, while the sand just below and above the Mimachlamys level was exposed over the entire floor of the Middelares building site, but most probably, the occurrence of partial skeletons has a patchy distribution;

5) the absence of inarticulate brachiopod Discinisca fallens in the faunal listings of Middelares. At AIA, this species occurs in layers $5 \mathrm{c}$ and $5 \mathrm{~b}$, and reworked in layer 4 , and was not collected from layers $5 \mathrm{a}$ and 3 . The absence is thus most probably related to differing outcrop conditions with the correlated parts of $5 \mathrm{c}$ not being exposed at Middelares, and possibly also to much lower volumes of sediment that were sieved from the Mimachlamys level.

Summed up, Middelares and AIA document a nearly identical stratigraphic sequence with a twofold Diest Formation more than 1.80 to $2.40 \mathrm{~km}$ apart. 


\section{Older outcrops and a plethora of names}

The 'Sables gris mouvants', 'Sables gris', 'Roche à bryozoaires', 'Sables à bryozoaires', 'Sables verts', 'Sables à Terebratula perforata', 'Sables à Terebratula grandis', 'Sables moyens', 'assise à Terebratula perforata', 'Sables verts à Hétérocètes', 'Sables et grès à Hétérocètes' are all 19th to early 20th century names that represent wholly or partially the 'Sables de Deurne' of Glibert \& de Heinzelin de Braucourt (1955a) and the Deurne Member of De Meuter \& Laga (1976). This plethora of names resulted from the sometimes-vivid debates amongst 19th century researchers (see Glibert \& de Heinzelin de Braucourt, 1955a for an introduction) and rooted in the combination of the much too restricted nature of the outcrops (too temporary, too limited in number, too shallow diggings, too little laterally extended, too little time for examination) and of the heterogeneous nature of the sediment and the fossil occurrences therein. Many of the discussions incorrectly focused on e.g. the color of the sediment, the presence or absence of certain fossils like bones of marine mammals (viz. 'hétérocètes') or brachiopods (viz. Terebratula grandis or $T$. perforata), or different types of concretions, all characters which we now would define as inapt for their use as sole criterion for the identification of lithostratigraphic units.

Regardless of the many shortcomings, quite a number of important clues on the characterization and occurrence of the Diest deposits in the Antwerp area lie hidden in these 19th and early 20th century works, as well as in a number of more modern reports on temporary outcrops related to the construction of the R1 at Borgerhout and Antwerp in the late 1960s (e.g. van den Bosch, 1967a, 1967b, 1967c; De Meuter et al., 1967, 1976; Ringelé, 1974; De Meuter, 1974) which can be interpreted based on the insights gained from AIA and Middelares.

Of all the 19th century works, Dejardin (1862), Cogels (1874), Mourlon (1876) and Van den Broeck (1878) held most of the clues, and Van Straelen (1920) of all the early 20th century works. Dejardin (1862) studying the many ditches of the fortifications of the city of Antwerp, added to his descriptions two lengthy profiles, one along the capital ditch of the enclosure (viz. the inner circle of the defenses) and another along the ditches of the main face of the eight forts (viz. the outer circle) (Fig. 1). He identified two different deposits, named 'sables gris' and 'sables verts', the former being restricted to the ditches of Forts 1, 2 and 3, and the latter being present all along the two profiles (except at Fort 8, see Fig. 1). The description of his 'sables gris' as calcareous glauconiferous sand containing large amounts of bryozoans, echinoids, mollusk shells, terebratulids and lingulids, with a typical odor and calcareous sandstone at their base, clearly indicates a correspondence to Unit 2. His 'sables verts', defined as greenish-colored glauconiferous sand generally devoid of fossils, became much better described by Mourlon (1876), Cogels (1874) and Van den Broeck (1878), based on additional observations on relatively thin sequences $(<0.5 \mathrm{~m})$ of these 'sables verts' in the ditches of the enclosure between the Borsbeekse Poort and the Turnhoutsebaan at Antwerp (Fig. 1; localities 37, 40-47 in Glibert \& de Heinzelin de Braucourt, 1955a). Mourlon (1876) recognized two levels within these 'sables verts', drawn as beds 4 and 5 on his profiles, in which the lower part of these 'sables verts' was characterized by gravelly glauconiferous sand and the upper part especially by concretions and terebratulids. The invertebrate fauna from the lower part was said to be poorly diverse, lying in horizontal beds, and essentially composed of terebratulids, pycnodontids and pectinids (Cogels, 1874; Mourlon, 1876; Van den Broeck, 1878). Vertebrate fossils were locally common, from isolated bones to complete skeletons of marine mammals, many of them pertaining to the mysticete Heterocetus. Terebratulids were most abundant in the upper part of the 'sables verts', both in the sandstone concretions containing cetacean bones and in the sandstone concretions containing bryozoans as well as a characteristic fauna of small mollusks in mold preservation (viz. the 'Roche à bryozoaires' of the Borsbeekse Poort). In the latter ones, terebratulid shells were frequently overgrown by bryozoans. According to Mourlon (1876), many of the bones recovered from the upper part of the 'sables verts' seemed to exhibit a characteristic type of erosion, indicating signs of abrasion. Mourlon (1876) also described a peculiar case of a cetacean skull encased in sandstone with the upper part sticking out of the sandstone showing signs of abrasion, but with the remainder of the skeleton intact in nonagglutinated sand next to the skull in the sandstone. Cogels (1874, p. XLV) discovered that lingulid brachiopods were also present in abundance in the upper part of the 'sables verts', already occurring below the levels with bryozoans, and that those lingulids did not occur reworked in horizontal beds as sometimes debris of terebratulids did, but that they occurred dispersed in the masses of the 'sables verts', accompanied by terebratulids. With AIA and Middelares in mind, it seems that these 'sables verts' correspond to a remainder of Unit 1 overlain by Unit 2, either with a lag deposit of the top of Unit 1 at the base of Unit 2, or possibly even a lag deposit of both Unit 1 and Unit 2 at the base of the overlying (?Pliocene) sequence, and that in all likelihood these scenarios may have occurred along the stretch between the Borsbeekse Poort and Turnhoutsebaan.

Another interesting line of evidence can be found in Van Straelen's (1920) descriptions of a temporary outcrop for the construction of a sewer at Deurne Muggenberg (Fig. 1; locality 58 on map of Glibert \& de Heinzelin de Braucourt, 1955a). These descriptions also give additional insights in the lateral variations that can be encountered across short distances in a Deurne Sand outcrop. The diggings were $6 \mathrm{~m}$ deep, of which the lowermost $3 \mathrm{~m}$ (base of the Deurne Sand not reached) exposed glauconiferous quartz sand without clay, but with gravelly zones containing large quartz and dark flint grains, in which the fossils were deposited in beds, with lingulids, terebratulids, oysters and pectinids being the dominant ones. In the uppermost $50 \mathrm{~cm}$, the sand was rubified and contained many concretions, all showing signs of reworking, amongst which Van Straelen identified 1) a ferruginous type, with molds of large bivalves and gastropods, 2) a calcareous cemented sandstone type, fragmented, highly fossiliferous, with Ditrupa, bryozoans, and frequently bioeroded by lithofageous bivalves, next to 3) yellowish calcareous concretions made up of very abraded debris of bryozoans, terebratulids, gastropods, bivalves and echinoids. This uppermost part passed both laterally and downward almost imperceptibly (according to the author) into generally nonfossiliferous sand with lingulids and bioturbations of the quartz and glauconite separating type. These bioturbations occurred both in spots and irregular bands of variable thickness. This passed again laterally into a level with calcareous sandstone containing bryozoans and once more into friable tuffaceous sand made up of strongly abraded debris of bryozoans, brachiopods, bivalves and gastropods, serpulids, echinoids, decapods and cirripedes, and bones of fishes and marine mammals. Clearly, the topmost part of this outcrop corresponds to a highly irregular erosive surface with lag deposit that postdates the Deurne Sand sequence, with the ferruginous concretions with large mollusks originating from younger deposits. The upper part of the sand below this erosive surface clearly correlates to Unit 2 and must have been deposited in relatively shallowly incised troughs with intensely bioturbated foresets with bryozoan reefs developed in some of them. Some of these reefs remained quite intact and must have been quickly buried, but most became, together with 
the calcareous remains of their inhabitants, partly or even fully abraded and turned into tuffaceous sand and calcareous cemented sandstone. The more horizontally bedded lower part of the outcrop displays many of the characters of Unit 1.

The possible twofold division of the Diest sequence at Antwerp was thus already in the mindset of several of the 19th century workers. Dejardin (1862) realized that the fauna from his 'sables verts' still resembled in several aspects that of the underlying middle Miocene Antwerpen Sand (viz. 'sables noirs'), something which was not present anymore in his 'sables gris' which had a more 'Pliocene' composition. The idea of the possible twofold division would slowly fade away during the 20th century, and although Glibert \& de Heinzelin de Braucourt (1955a) revised all previous literature, no hints for the possible twofold division can be found in their definition of their 'Sables de Deurne' as a complex facies with both calcareous glauconiferous sandstone, sand and sandstone with bryozoans, bioturbated sand of quartz/glauconite separation type, masses of terebratulids and bryozoans and gravelly sand with skeletal remains of marine mammals. Glibert \& de Heinzelin de Braucourt (1955a) must have been largely hampered by the complete lack of any Deurne Sand outcrop at the time of their investigations. Thirty years later, De Meuter \& Laga (1976) would even narrow the description of the Deurne Sand to 'graygreen medium fine, very slightly clayey, glauconiferous sand; locally very rich in nests of Bryozoa, Brachiopoda and Ditrupa; typical whitish tracks with dark glauconite coating', thus leaving away all hints for a possible twofold division. More than probably, their views were biased by the nature of the outcrops of their time, in which only thin Deurne Member sequences were exposed.

At Borsbeekse Poort (I BP \& II BP) and Stenenbrug (I SB) (Fig. 1), De Meuter et al. (1976) attributed the 20-30 cm interval to a completely reworked remainder of the Deurne Sand intermixed with younger Kattendijk Formation deposits, adding evidence that some parts of the outcrops studied by Dejardin, Mourlon, Cogels and Van den Broeck discussed above represent partially or fully reworked Deurne deposits. Better preserved and a bit thicker Deurne Sand sequences were found more to the north, at Borgerhout Rivierenhof (70-95 cm at VII BR; De Meuter et al., 1967, 1976; $75 \mathrm{~cm}$ at XI BR; De Meuter et al., 1976) and Borgerhout Foorplein ( $2 \mathrm{~m}$ of very fossiliferous sand with bryozoans at XV BR; Ringelé, 1974). The loosely stacked gray-green medium fine locally fossiliferous sand with typical bioturbation and dispersed nests of bryozoans and Ditrupa, large numbers of the brachiopod Cryptopora nysti (as 'Mannia' nysti) and a poorly developed basal gravel with small dark flint pebbles, bone fragments and rare shark teeth (VII BR \& XI $\mathrm{BR})$, as well as the $2 \mathrm{~m}$ thick highly fossiliferous bryozoan-rich interval sampled by Ringelé (1974), allow us to conclude that these outcrops only exposed Unit 2 sequences, in which only some of the reworked teeth, bones and pebbles found in the basal gravel (called Rivierenhof gravel in De Meuter, 1974) may have originated from the reworking of Unit 1. A description by Marquet \& Herman (2009) of an additional section at Rivierenhof with a $30 \mathrm{~cm}$ thick interval with gravel in yellowish sand with gray sandstone, dispersed shells, shark teeth and cetacean bones often in anatomical connection further confirms the latter interpretation. Van den Bosch's (1967a, $1967 b, 1967 \mathrm{c}$ ) description of a number of exposures between Stenenbrug and Turnhoutsebaan (Fig. 1) adds additional confirmation, and additionally reveals the difficulties in differentiating in situ Deurne Sand from their reworked counterparts. The sometimes highly irregular contact with the overlying sequence was detailed by De Meuter et al. (1967, coupe B).

These lengthy discussions are necessary to reveal that the twofold division is recognizable all over the Antwerp area, and that three episodes of erosion define the Deurne Sand sequence found in outcrops. These episodes date to times 1) just prior to or during the basal scouring of the Unit 2 troughs; 2) during the deposition of Unit 2 by different troughs scouring earlier deposited infills, and 3) postdating the deposition of the Diest Formation in the Antwerp area. This conclusion has major implications for future studies of the Diest Formation deposits, and certainly for those studying their fossil content. In the light hereof, it is more than probable that the 'mythical' 'Sables à Hétérocètes' and 'Grès à Hétérocètes' resulted both from nonreworked Unit 1, reworked Unit 1, reworked Units $1+2$ and reworked Units $1+2$ added with younger material (base Pliocene Kattendijk Sand or a yet unidentified upper Miocene sequence; see discussion in Bosselaers et al. 2004). Some recent observations at a temporary outcrop at Waterbouwkundig Labo (Fig. 1, previously 'Lunette de Deurne' and 'Ancienne boucherie militaire', locality 38 on map of Glibert \& de Heinzelin de Braucourt (1955a), and also the locality where van de Wouwer collected many specimens that are now in the collections of RBINS), confirm this hypothesis. Here, in situ Unit 1 green glauconiferous sand with many Mimachlamys angelonii holding many (partial) articulated vertebral columns of marine mammals is almost imperceptibly overlain by a level with different types of concretions, including those informally named 'Broechem nodules', bones showing signs of abrasion and bivalves that indicate an age younger than the Deurne Member (Kattendijk Formation or a yet unidentified upper Miocene sequence).

\section{Biostratigraphy and age dating}

Dinoflagellate cyst assemblages from three AIA samples (see Table 2; LP1-13 from Layer 5c, LP1-15 from Layer 5b and LP1-19 from Layer 3) were biostratigraphically interpreted following the age-calibrated dinoflagellate cyst biozonation of Dybkjær \& Piasecki (2010) which was defined in both onshore and offshore settings in Denmark, thus within the same North Sea Basin. A comparison with the formerly used biozonation for the Diest Formation (e.g. Louwye, 2002; Louwye \& Laga, 2008; Louwye et al., 1999, 2007; Vandenberghe et al., 2005, 2014) by de Verteuil \& Norris (1996) is also given. Additional input came from Louwye (2002) who studied samples of Borgerhout Rivierenhof sections VII B.R. and XIV B.R. As was discussed in the previous chapter, the trace fossils and nests of Ditrupa indicate that these sections represent Unit 2 correlatives with a thin lag deposit of eroded Unit 1 at their base.

Based on the occurrence in the lowermost of the three samples (LP1-13) of Gramocysta verricula, the entire AIA sequence postdates the late Serravallian and, according to the age model of Dybkjær \& Piasecki (2010), 12.8 Ma. The biostratigraphical interpretation of the lowermost sample LP113 proved not to be straightforward given the low abundance and the poor preservation of the dinoflagellate cysts. Due to the absence of Amiculosphaera umbraculum, a species which lowest occurrence at $11.4 \mathrm{Ma}$ defines the base of the $A$. umbraculum Zone of Dybkjær \& Piasecki (2010) (Fig. 20), sample LP1-13 could belong to the G. verricula Zone. However, the absence of $A$. umbraculum might be the result of the low abundance and the poor preservation of the dinoflagellate cysts encountered in the sample. Or, and in addition, its absence may be related to its preference for open marine environments (Dybkjær \& Piasecki, 2010). The presence of the species in most but not all Rivierenhof samples of Louwye (2002) further suggests this hypothesis.

The preservation of the dinoflagellate cysts in samples LP115 and LP1-19 was reasonable, but identification was still hampered by the substantial amount of dispersed organic matter. 


\begin{tabular}{|c|c|c|c|c|c|c|}
\hline \multirow{3}{*}{$\begin{array}{ll}\text { Dinoflagellate cysts } & \text { Sample } \\
\end{array}$} & \multirow{2}{*}{\multicolumn{2}{|c|}{$\frac{\text { Unit } 1 \text { - Layer 5c }}{\text { LP1-13 }}$}} & \multirow{2}{*}{\multicolumn{2}{|c|}{$\frac{\text { Unit } 1 \text { - Layer 5b }}{\text { LP1-15 }}$}} & \multirow{2}{*}{\multicolumn{2}{|c|}{$\frac{\text { Unit } 2 \text { - Layer } 3}{\text { LP1-19 }}$}} \\
\hline & & & & & & \\
\hline & $\mathrm{n}$ & $\%$ & $\mathrm{n}$ & $\%$ & $\mathrm{n}$ & $\%$ \\
\hline Achomosphaera andalousiensis & 6 & 3,35 & 15 & 5,88 & 2 & 0,77 \\
\hline Amiculosphaera umbracula & & & 1 & 0,39 & & \\
\hline Barssidinium graminosum & & & & & 2 & 0,77 \\
\hline Barssidinium pliocenicum & 1 & 0,56 & 5 & 1,96 & 1 & 0,38 \\
\hline Batiacasphaera minuta & 7 & 3,91 & 14 & 5,49 & 27 & 10,38 \\
\hline Batiacasphaera micropapillata & 2 & 1,12 & 5 & 1,96 & 2 & 0,77 \\
\hline Bitectatodinium arborichiarum & 3 & 1,68 & 3 & 1,18 & 14 & 5,38 \\
\hline Bitectatodinium serratum & 2 & 1,12 & 1 & 0,39 & 1 & 0,38 \\
\hline Bitectatodinium tepikiense? & & & & & 2 & 0,77 \\
\hline Dapsilidinium pseudocolligerum & & & 2 & 0,78 & 1 & 0,38 \\
\hline Geonettia sp. ind. & 3 & 1,68 & & & & \\
\hline Gramocysta verricula & 14 & 7,82 & 3 & 1,18 & & \\
\hline Habibacysta tectata & 5 & 2,79 & 4 & 1,57 & 2 & 0,77 \\
\hline Hystrichosphaeropsis obscura & & & 1 & 0,39 & 1 & 0,38 \\
\hline Hystrichokolpoma rigaudiae & 2 & 1,12 & & & & \\
\hline Invertocysta lacrymosa & 1 & 0,56 & 1 & 0,39 & 4 & 1,54 \\
\hline Impagidinium paradoxum & 7 & 3,91 & 2 & 0,78 & & \\
\hline Labyrinthodinium truncatum truncatum & 9 & 5,03 & 12 & 4,71 & 3 & 1,15 \\
\hline Lejeunecysta sp. ind. & 2 & 1,12 & & & 1 & 0,38 \\
\hline Lejeunecysta mariae & 2 & 1,12 & & & & \\
\hline Lingulodinium machaerophorum & 8 & 4,47 & 6 & 2,35 & 6 & 2,31 \\
\hline Melitasphaeridium choanophorum & 2 & 1,12 & 5 & 1,96 & 3 & 1,15 \\
\hline Operculodinium centrocarpum & 11 & 6,15 & 7 & 2,75 & 1 & 0,38 \\
\hline Operculodinium? eirikianum & 5 & 2,79 & & & 1 & 0,38 \\
\hline Operculodinium israelianum & & & 2 & 0,78 & & \\
\hline Operculodinium piaseckii & 4 & 2,23 & 2 & 0,78 & & \\
\hline Palaeocystodinium golzowense & 2 & 1,12 & & & & \\
\hline Palaeocystodinium miocaenicum & 1 & 0,56 & & & & \\
\hline Pentadinium laticinctum & 1 & 0,56 & & & & \\
\hline Quinquecuspis concreta & 6 & 3,35 & 4 & 1,57 & 1 & 0,38 \\
\hline Reticulatosphaera actinocoronata & & & 5 & 1,96 & 1 & 0,38 \\
\hline Selenopemphic brevispinosa & 6 & 3,35 & 8 & 3,14 & & \\
\hline Selenopemphix nephroides & 2 & 1,12 & & & & \\
\hline Spiniferites spp. ind. & 45 & 25,14 & 136 & 53,33 & 42 & 16,15 \\
\hline Sumatradinium druggii & & & 2 & 0,78 & & \\
\hline Sumatradinium soucouyantiae & 2 & 1,12 & & & & \\
\hline Tectatodinium pellitum & 6 & 3,35 & 4 & 1,57 & & \\
\hline $\begin{array}{l}\text { Tuberculodinium vancampoae } \\
\text { Acritarchs }\end{array}$ & & & 1 & 0,39 & 1 & 0,38 \\
\hline Cyclopsiella? granosa/elliptica & & & & & 56 & 21,54 \\
\hline Paralecaniella indentata & 10 & 5,59 & 3 & 1,18 & 84 & 32,31 \\
\hline Palaeostomocystis globosa & & & & & 1 & 0,38 \\
\hline Small spiny acritarch & 2 & 1,12 & & & & \\
\hline Green algae & & & & & & \\
\hline Tasmanites sp. ind. & & & 1 & 0,39 & & \\
\hline Palynomorphs counted & 179 & & 255 & & 260 & \\
\hline
\end{tabular}

Table 2. Dinoflagellate cysts, acritarchs and green algae recovered from three AIA samples LP1-13 (Layer 5c, Unit 1), LP115 (Layer 5b, Unit 2) and LP119 (Layer 3, Unit 2. Counts (n) and percentages $(\%)$ given for each sample. Total palynomorphs counted per sample given.
The presence of a single specimen of the index species $A$. umbraculum in sample LP1-15 is noteworthy and it is indicative of the presence of the A. umbraculum Zone (Dybkjaer \& Piasecki, 2010), defined by the lowest occurrence of the eponymous species to the lowest occurrence of Barssidinium evangelineae. However, an attribution of both samples to the $A$. umbraculum Zone remains tentative given the absence of Paleocystodium golzowense in both samples, a key species with a highest occurrence at the upper boundary of the latter zone. Furthermore, the index species $B$. evangelineae of the superjacent Hystrichosphaeropsis obscura Zone and the time equivalent DN9 Zone of de Verteuil \& Norris (1996), was not recorded. Other species of the genus Barssidinium are recorded in both samples. The A. umbraculum Zone was deposited during early to mid Tortonian times between 11.4 and $8.8 \mathrm{Ma}$ (Dybkjær \& Piasecki, 2010). Following the biozonation by de Verteuil \& Norris (1996), both samples LP1-15 and LP1-19 can be placed within their DN8 Zone.
In summary, dinoflagellate cyst biostratigraphy allows to infer that sample LP1-13 is younger than 12.8 Ma. Preservation and diversity of the marine palynomorphs hampers a more precise age assessment. Samples LP1-15 and LP1-19 are deposited some time during the interval 11.4 and $8.8 \mathrm{Ma}$ and hold the $A$. umbraculum Zone. The superjacent Hystrichosphaeropsis obscura Zone of Dybkjær \& Piasecki (2010) (8.8-7.6 Ma) and the DN9 Zone of de Verteuil \& Norris (1996), is unrecorded in the AIA and Rivierenhof samples favoring adherence to the A. umbraculum and DN8 zones for both Unit 1 and Unit 2.

Further refinement comes from the integration with calcareous microfossils, in particular of the presence of Bolboforma metzmacheri, a species which was reported to occur abundantly in the Rivierenhof sections VII BR and XIV BR (De Meuter, 1974; Willems, 1976; Spiegler, 2001). Several slightly different age dates have been proposed for the range of $B$. metzmacheri and the eponymous zone, but according to the 


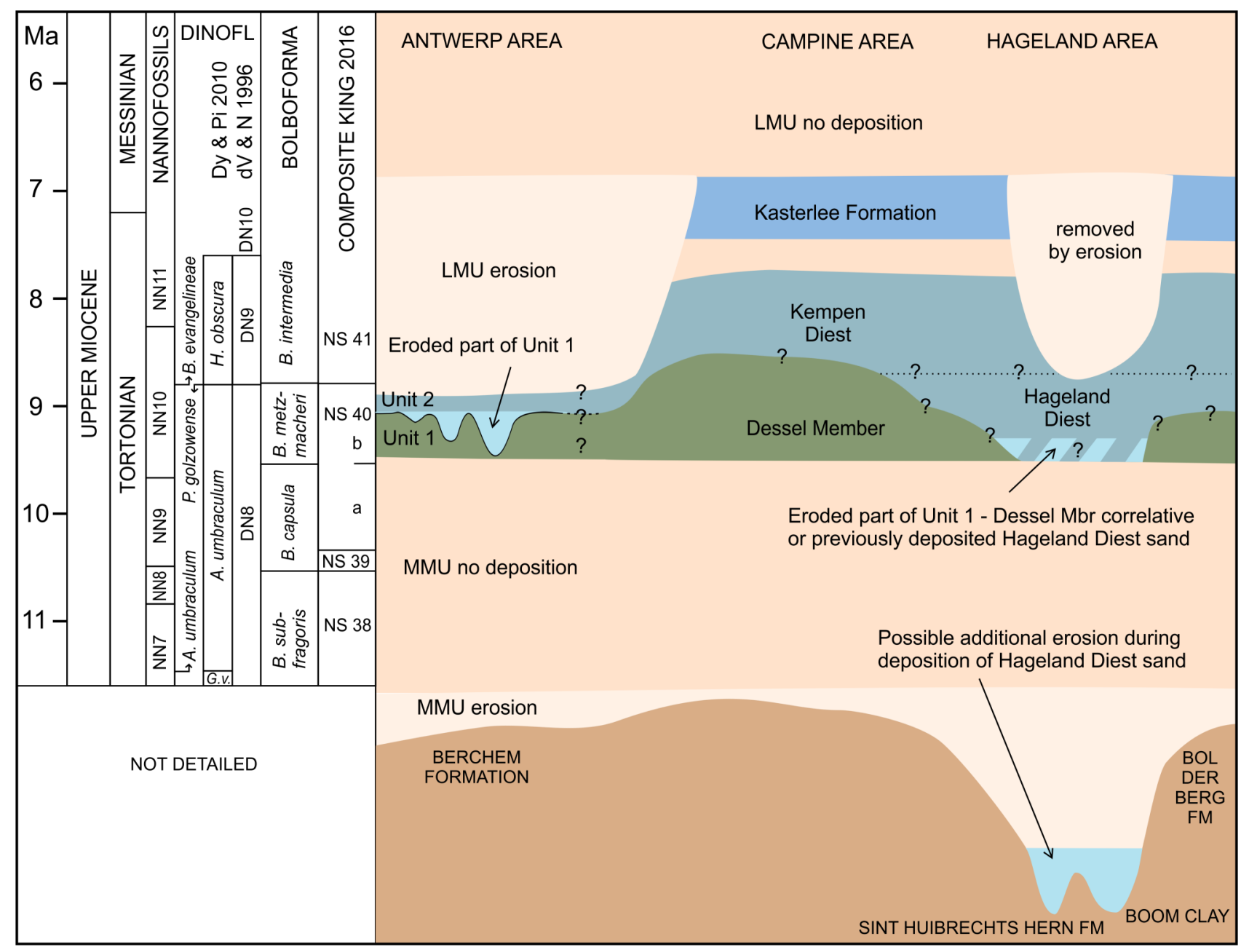

Figure 20. Unit 1 and Unit 2 placed in an age-calibrated biostratigraphical context, and tentative correlation to Diest Formation deposits between the study area and the Roer Valley Graben. An extended Mid Miocene Unconformity (MMU) incorporates more than 2 million years of the Tortonian characterized by non-deposition and erosion of older sediments predating the onset of the deposition of the Diest Formation. Erosion related to the Late Miocene Unconformity (LMU) removed all possibly deposited sediments in the Antwerp area postdating Unit 2. Age model, nannofossil and dinoflagellate biostratigraphy after Dybkjær \& Piasecki (2010), age model for Bolboforma metzmacheri after King (2016). Abbreviations: NN: Nannofossil zone; DINOFL: dinoflagellates; Dy \& Pi 2020: Dybkjær \& Piasecki (2010); dV \& N 1996: de Verteuil \& Norris (1996); $A$ : Amiculosphaera; P.: Palaeocystodium, B.: Barssidinium; G.v.: Gramocysta verricula, H.: Hystrichosphaeropsis; B.: Bolboforma; NS: North Sea Composite Zones of King (2016); FM: Formation. For discussion on the Diest Formation and its depositional models, see Houthuys et al. (2020, this volume).

integration of the North Sea Basin biozonal schemes of King (2016), its stratigraphic range lies between $9.54 \mathrm{Ma}$ and 8.78 $\mathrm{Ma}$, thus corresponding to the upper part of the A. umbraculum Zone $(760 \mathrm{ka})$ and the very lowermost part $(20 \mathrm{ka})$ of the $H$. obscura Zone. No samples from AIA have been inspected for the presence of Bolboforma, and at Middelares, B. metzmacheri was unrecorded and undiscussed by Hooyberghs \& Moorkens (2005). Unfortunately, the presence of dextrally coiled Neogloboquadrina atlantica ( $N$. pachyderma) in the upper unit at Middelares (Hooyberghs \& Moorkens, 2005) does not add additional insights.

B. metzmacheri was also recorded in the intensively bioturbated fine-grained glauconiferous quartz sand formally named Dessel Sand Member by Laga \& De Meuter (1972) (Willems, 1976; Spiegler, 2001) and found below coarser grained Diest Formation deposits in the subsurface of the Campine area (Houthuys et al., 2020, this volume). While the first definition of the Dessel Member focused on calcareous fine -grained deposits, it is primarily the finer grain size which was used subsequently to identify the Dessel Sand Member in boreholes. In many boreholes, the lower calcareous part is surmounted by an upper non-calcareous part, informally named lower and upper Dessel Member by Adriaens (2015), but the latter author found no significant differences between the grain size, pelletal glauconite content and clay mineralogy. The lower part of the Dessel Sand Member in the Mol (GSB code 031W0221; DOV code kb17d31w-B212) and Retie (GSB code 031W0243; DOV code kb17d31w-B228) boreholes hold the DN8 Zone, while the upper part of the member in these boreholes hold the DN9 Zones (Louwye et al., 1999). The greater part of the Dessel Member in the Poederlee (GSB code 030W0300; DOV code kb16d30w-B315) and Oostmalle (GSB code 029E0249; DOV code kb16d29e-B276) boreholes hold the DN9 zone, the DN8 only being present in the very base of the Oostmalle borehole (Louwye et al., 1999). Foraminifera place the lower calcareous part of the Dessel Member in the benthic foraminifer Zone BN3 (Laga \& De Meuter, 1972), and the association of Uvigerina venusta deurnensis and U. pigmea langeri (De Meuter, 1974) indicates Zones NS40 or NS41 of King (2016). Amongst the planktic foraminifera, dextral Neogloboquadrina atlantica (Globigerina pachyderma in Laga \& De Meuter, 1972) is common (King, 2016). Thus, both in age and their fine-grained intensely bioturbated character, the Dessel Member and Unit 1 seem to correlate, at least to some extent. In 
pelletal glauconite content, these seem to differ slightly. More significantly, the absence of the coarser fraction observed throughout Unit $1(>355 \mu \mathrm{m})$ in grain-size plots of the Dessel Member (see e.g. Adriaens, 2015) and the lower percentages of the fine sand fraction, set both deposits apart. Unit 1 may thus be interpreted as an Antwerp area equivalent of the Dessel Member. Interesting in this discussion is the single sample from the finer-grained part of the Diest Formation of the Veerle borehole (GSB code 060E0215A; DOV code kb24d60e-B219) dated to the DN8 Zone analyzed by Verhaegen $(2019,2020)$. The Veerle borehole locates inside one of the deeper gullies of the Hageland area, thus more to the south than the Dessel Member occurrences in the subsurface of the Campine area (Vandenberghe et al., 2014; Houthuys et al., 2020, this volume). Here, the grain-size frequency distribution curves show some similarities with those of Unit 1 with e.g. two well-identifiable peaks. However, while the mode of the second peak is close to that of Unit 1, the mode of the first peak differs and is smaller. The basal gravel also seems to be less developed in the Dessel Member than at the base of Unit 1 (Houthuys et al., 2020, this volume), but this may be an artefact of comparing outcrop with borehole data. The position of this basal gravel on top of (primarily) Berchem Formation deposits of both the Dessel Member and Unit 1 indicates that the base of both deposits is positioned on top of the Mid Miocene Unconformity (MMU). In the Antwerp area, the combination of the erosive character of the base of the Diest Formation, the fact that several authors have described the top of the Antwerpen Sand Member as a firmground and the time gap between the youngest Antwerpen Sand Member deposits (Achomosphaera andalousiensis Zone, Serravalian, 13.2-12.8 Ma, Louwye et al., 2020, this volume) and the oldest relative dated Diest Formation (within the $B$. metzmacheri Zone thus younger than $9.54 \mathrm{Ma}$, middle Tortonian), is clearly indicative of a prolonged period of nondeposition combined with erosion during the Serravallian and early Tortonian (=MMU). From the Rijkevorsel borehole (GSB code 016E153; DOV code kb8d16e-B37), Gulinck \& Laga (1975) reported the presence of Bolboforma metzmacheri and dextrally coiled Neogloboquadrina atlantica (as Globigerina pachyderma) in the lowermost part of the Dessel Member (between 135.9-138.1 m), meaning that it is a valid option that the age of the base of the Dessel Member can be refined to within the upper part of the DN8 Zone, younger than 9.54 Ma, meaning that in the Campine area and, by extension, probably also in the Antwerp area, the MMU would have extended up to $2.1 \mathrm{Ma}$ into the Tortonian. The presence of weathered flints at the base of Unit 1 at AIA fits the supposed long hiatus.

\section{Synthesis of the depositional environment}

At AIA, at some time in the middle Tortonian between 9.54 and 8.8 Ma (see Fig. 20), the MMU must have been followed by a marine transgression creating a tidal embayment with at its base a tidal ravinement surface lined with a lag deposit of the heaviest particles of the previously eroded sediments (flint pebbles, phosphatic concretions). Layer 6 is interpreted as a subaquatic mass flow deposit also related to this surface, demonstrating that the transgression flooded a surface with some relief. The somewhat confined environment with an incised surface can also be inferred from the lower meter of layer 5 which is characterized by a large heterogeneity of the grain sizes with broadly smeared out frequency distribution curves evidencing poor sorting, very high glauconite contents $(60-45 \%)$, the presence of both very large glauconite and quartz grains in these samples, the strong variations in the granulometry, in particular the strong variations in the fines $(<125 \mu \mathrm{m})$ and the fact that they represent an important volumetric percentage, next to the important addition of a coarse fraction $(>250 \mu \mathrm{m})$, and the presence of isolated $\mathrm{cm}$-sized flint pebbles up to $1 \mathrm{~m}$ above the base. Environmental conditions must have varied considerably over (possibly short lapses of) time in the lowest meter of Unit 1 . The pycnodontid bed $20 \mathrm{~cm}$ above the base of the Unit indicates that sometimes sediment accumulation must have halted, allowing for a colonization of the seafloor by fully marine bivalves (pycnodontics and pectinids). With the pycnodontid shells lying next to rather than on top of each other, and without large specimens and several generations of shells being observed, this colonization must have been stopped fairly quickly by renewed sedimentation characterized again by poor sorting and high pelletal glauconite contents. Between half a meter and a meter above the base of Unit 1 (between LP1-10 and LP1-11, see Fig. 15), the sediment grades into better sorted glauconiferous sand with two wellseparated peaks in the grain-size frequency distribution curves. This interval coincides with the onset of the large accumulation of skeletal remains of marine mammals and the onset of intense bioturbation of the sediment. The 60-70 cm deep Ophiomorpha reaching to the lowermost part of Unit 1 are a further clue. From this interval on, the sediment accumulation rate must have had an equilibrium between slow enough to allow for the intense bioturbation fading out primary sedimentary structures and the 'relatively' fast burial of skeletons prior to their entire decay. The fact that several of these skeletons preserved on their upwards side traces of bio-erosion and/or partial decay means that they must have sat some time on the seafloor prior to having been completely buried. The presence of bite marks of sharks also fits into this scenario, although some of these marks may already have been created prior to the carcass arrival at the seafloor. The absence of barnacles or traces of them on the bones is remarkable and may indicate considerable water depths. The intensity of the bioturbation also suggests a relatively low energy setting in normal (marine) salinity conditions. The low energy settings corroborate with the abundance of marine mammal skeletons preserved in anatomical position. The few sedimentary structures that survived fading from bioturbation indicate the presence of closely spaced thin mud drapes (Fig. 5F), locally inserted in thin cross beds, which demonstrates foreset lamination of small, 10$15 \mathrm{~cm}$ high tidal current dunes. Together with the large-scale subhorizontal aggradation of Unit 1, the depositional environment may have been that of a confined marine tidal inlet with some depth (in the order of $50 \mathrm{~m}$ ). The presence of both suspension (fine) and traction (coarser) clastic material supports the interpretation of a confined marine environment. Together with the presence of wood logs, and in layer $5 \mathrm{~b}$ also of cones and seeds, a relatively short distance to shore may be inferred. Somewhat shallower settings for layer $5 \mathrm{~b}$ than the lower meter of layer $5 \mathrm{c}$ were suggested by the chondrichthyan assemblage. However, while a significant drop in the abundance of large predatory sharks also evidenced this change, the abundance at the Middelares outcrop of skeletons of marine mammals in contemporaneous beds of layer $5 \mathrm{a}(10 \mathrm{~cm}$ above the Mimachlamys level) prove that prey did not disappear altogether from the Antwerp area. The latter hints that the local abundance of carcasses probably was the most important constraint for the presence or absence of large predatory sharks in the environment. Regardless of the chondrichthyans, the glauconite content remains the same throughout the upper part of layer $5 \mathrm{c}$ as well as throughout the layers $5 \mathrm{~b}$ and $5 \mathrm{a}$, so that the relative sea-level drop may best be explained as primarily related to the reduction in sediment accommodation space due to the filling of the basin.

The depositional environment of Unit 2 was more energetic than that of Unit 1. The thick, trough-shaped cross-beds are the depositional product of the migration of very large hydraulic 3D 
dunes, with dune heights exceeding $4 \mathrm{~m}$. The steeply sloping, very straight foreset planes developed in the full vortex stage of the very large dunes. This implies very strong and thus probably channelized flow currents. The foreset dip shows that the dunes migrated to the east; this flow direction can in the context of the Diest Formation be interpreted as the ebb flow (Houthuys, 2014). The observed cross-bed thickness implies an estimated water depth at deposition between 30 and $50 \mathrm{~m}$ (Allen, 1966). The sand and fossils found at the base of Unit 2 show a large degree of reworking of Unit 1 material, into which Unit 2 is incised. The alternation of strongly burrowed with less burrowed foreset packages implies intermittent dune progradation, possibly in relation with the arrival at the large dunes' brink of superimposed smaller dunes. The high numbers of the acritarch species Cyclopsiella granosalelliptica and Paralecaniella indentata $(21.5 \%$ and $32.3 \%$, respectively) in sample LP1-19 indicate a somewhat shallower environment of Unit 2 than Unit 1 . According to a review by Louwye \& Laga (2008) of the paleoecology of the latter species, high numbers of Paralecaniella indentata are indicative for deposition in marginal marine or stressed environments, while Cyclopsiella granosalelliptica thrives in shallow marine to nearshore high energetic environments. At Rivierenhof (Louwye, 2002), the two species were also accompanied by Cyclopsiella? trematophora which has similar paleoecological preferences. In addition, the three species are known to be clustered when lying on the seafloor (see Louwye \& Laga, 2008). Alternatively, these acritarchs may have been transported by the currents from very nearby shallower environments. The same may have occurred with the bryozoans found in the southernmost trough in LP1, because the high energetic environments and movement of the seafloor do not corroborate with their burial in life position. Even though temporal pauses in the movement of the foresets allowed colonization by polychaetes, they were probably not long enough to allow the foresets to be colonized by sessile biota. Given the good preservation of many large and branched specimens, the bryozoan reefs must have been very nearby. They supported a specific and diverse, and mostly small, invertebrate fauna. The high energetic environment is probably also responsible for the less diverse vertebrate fauna. Currently, a more refined estimate than $30-50 \mathrm{~m}$ paleodepth cannot be proposed based on the sedimentology, trace fossil association and fauna found at AIA. This estimate is in accordance with the one proposed by Glibert \& de Heinzelin de Braucourt (1955a, $1955 \mathrm{~b} ; 30-50 \mathrm{~m}$ ). While balanid cirripeds were not observed in Unit 1, a few were found in layer X, and also Glibert \& de Heinzelin de Braucourt (1955a, 1955b) reported on their rare presence within the Deurne Member fauna, indicating that water depths were possibly closer the 30 than to $50 \mathrm{~m}$ watermark. In all, the fauna of this unit merits additional studies, possibly allowing to further refine the paleodepth of the Antwerp area deposits.

\section{Contact between Unit 1 and Unit 2 and position within the Diest Formation}

A major yet unresolved issue remains the interpretation of the nature of the contact between Unit 1 and Unit 2 at AIA, which is next to erosional scouring marked by an abrupt change in sorting, grain size, amount of suspension material, glauconite content, sedimentary structures and trace fossil association. Several interpretations are possible. In a first scenario, this contact is interpreted as a sequence boundary resulting from a eustatic sea-level fall and rise. This could explain the erosive character, next to the differences in sorting, grain size, amount of suspension material and glauconite content, as well as the (albeit rare) finds of reworked Eocene shark teeth, but fails to explain the small size of the pebbles in the basal gravel. In addition, the time frame does not seem to fit with the current eustatic sea-level charts. In a second scenario, the contact is interpreted as an example of intraformational erosion; due to a change in the environment, the currents strongly increased, resulting in the erosion of previously deposited sediment, with the currents being sufficiently strong to locally also remove several meters of previously deposited sediment, even down to the underlying Antwerpen Sand Member. In this scenario, the erosive events will probably be more local and may not have a regional extent. The main flaw is that it does not seem to accommodate the large increase in glauconite content from $30 \%$ to $39-49 \%$, unless this would indicate sorting effects of the changed hydrodynamics. A third scenario that could explain the erosional scouring plus the change in environment is a previously unrecognized tectonic uplift occurring near the end of Unit 1. Within the North Sea Basin, tectonic events are common, and more events have recently become recognized (e.g. Dekkers \& Munsterman, 2020). In this scenario, the erosive character would have to be expressed throughout the basin than rather locally.

Important in this discussion is the correlation of Unit 1 and Unit 2 and the contact between them to Diest Formation sequences outside the Antwerp area (Fig. 20). Previously, the correlation of the Deurne Member to any of the other formal members and informal units of the Diest Formation remained poorly understood. Biostratigraphy places both units as time correlative to the lower half of the Dessel Sand Member in the subsurface of theCampine, to the fine-grained sequence found below coarser-grained Hageland deposits in the Veerle borehole in the Hageland area, and possibly also, to some extent, to the coarse Diest sand of the Hageland and southern Campine areas. However, from the latter, no age diagnostic microfossils were ever retrieved. With respect to the grain size, Unit 2 largely differs from Unit 1 and the Dessel Member by being coarsergrained and less-sorted, but at the same time, it is also somewhat finer-grained and better-sorted than most of the coarser-grained Diest sequences, although it may fall within the variation as observed in the samples studied by Adriaens (2015) and Verhaegen (2019). In addition, its pelletal glauconite content of $39-49 \%$ is much higher than that of the Dessel and Unit 1 sediments, but falls well within the variation of that of the coarser-grained Diest in the Campine and Hageland areas (compare Adriaens, 2015, fig. 5.41, but note that the boxplot for the Deurne Sand is incorrect; the three samples analyzed are RU208, RU209 and RU210 from AIA's Unit 2 and range from $39-46 \%)$. The sedimentary structures recall those seen in outcrops of the Hageland area. In this respect, Unit 2 shows resemblances with the bioturbated cross-bedded facies XT of Houthuys (2014). The most important difference between both is the lack of mud drapes, which characterize the Hageland cross beds and are indicative of strongly channelized tidal flow. The mineralogical composition of the clay and silt fraction differs from the coarser Diest in the Campine and Hageland areas, but this is most probably an effect of tidal currents being less polarized in the case of Unit 2. A less developed slack water stage during the turning of the tide may have prevented clastic suspended matter to settle so that the few remaining fines must rather have resulted from the abrasion of glauconite pellets. Currently, heavy minerals remain unstudied at AIA (and Middelares), and, in the light of the proposed twofold division of the Diest Formation in the Antwerp area, it is uncertain to which extent the dataset of Geets \& De Breuck (1991) used by Verhaegen (2019), Verhaegen et al. (2019) and Verhaegen (2020, this volume) represents a mixture of Unit 1 and Unit 2 correlatives.

In conclusion, the scenario that seems best supported by the currently available dataset is the one in which both units formed 
part of the Hageland Diest sand sequence of Houthuys et al. (2020, this volume). The twofold character of the Diest Formation in the Antwerp area suggests that also in the Hageland area a two-stage fill model (Verhaegen, 2019; Houthuys et al., 2020, this volume) can be inferred, in which a first cycle producing a fine-grained Unit 1 - Dessel Member equivalent (as that in the Veerle borehole) was subsequently almost entirely removed by erosional scouring during the deposition of the coarser-grained Hageland Diest sand, possibly correlating with Unit 2 . However, it may also be compatible with the model involving a lateral fill of a confined marine embayment followed by local flow constriction. Further research on AIA, Middelares, the Antwerp area Diest Formation, and all other Diest Formation outcrops and subcrops to the west of the Roer Valley Graben may help to better constrain the interpretation of the paleodepositional environment.

\section{Proposal for a revised lithostratigraphy: the new Borsbeek member (Unit 1) and redefinition of the Deurne Member (Unit 2)}

All field observations, collecting efforts and lab results from AIA, combined with a thorough revision of all other temporary outcrops previously documented in the literature all point to the same conclusion; the Diest Formation in the Antwerp area is not made up of one, but of two lithological units that differ in grain size, glauconite content, color, fossil associations and ichnofacies. Clearly, this conclusion conflicts with today's prevailing view of just a single unit Diest Formation in the Antwerp area. Therefore, a revised lithostratigraphy of the Diest Formation in the Antwerp area is proposed, with the introduction of the new Borsbeek member (Unit 1) and a redefinition of the Deurne member (Unit 2) as follows;

Borsbeek sand member (new):

Characterization: greenish-colored, intensely bioturbated, heterogenous glauconiferous, fine-grained quartz sand with an important clay-silt-very fine sand fraction $(<125 \mu \mathrm{m})(28-46 \%$, $62 \%$ at base) and variable amounts of median and coarse sand $(>250 \mathrm{~mm}$, high and variable (11-36\%) in the lower half, small and stable (7-8\%) in the upper half). Glauconite content of $30 \%$ throughout, except for a much higher content (45-60\%) in the basal part. A basal gravel with reworked phosphorites and different types of flints, flint pebbles residing in the sandy matrix occurs in the lowermost meter. Large-scale sedimentary structures are absent, except for horizontal bedding. The sediment may have a mottled appearance on mechanically dug vertical walls. An anomalously high concentration of marine mammal fossils may occur both in the lower and the upper half of the deposit. The invertebrate fauna is relatively poorly diverse, with pycnodontids and pectinids occurring in beds, while disciniscid (lower part) and lingulid (upper part) brachiopods are generally found dispersed. Terebratulid brachiopods are locally abundant.

Age/biozonation: middle Tortonian, upper Miocene. Dinoflagellates indicate the A . umbraculum Zone of Dybkjær \& Piasecki (2010) and the DN8 Zone of de Verteuil \& Norris (1996) (this paper). Most probably, the base falls also within the $B$. metzmacheri Zone, which allows to situate it in the time interval between 9.54 and $8.8 \mathrm{Ma}$.

Type locality and section: Temporary excavations at AIA, section LP1-A.

Geographical extent: Diest Formation in the Antwerp area (pro parte), partially to completely removed by erosion with only a lag deposit with reworked bones, pebbles and sandstone remaining in many sections (e.g. Rivierenhof gravel). Lateral equivalent of the Dessel Sand, known from boreholes only, especially in the eastern part of Belgium, where it reaches considerable thickness. However, it differs especially from the Dessel Sand by the addition of a coarse fraction. Its correlation to the finer-grained interval dated to DN8 at the Veerle borehole needs further study.

\section{Deurne Sand Member (revised definition):}

Diagnostic description: complex of facies deposited in trough-shaped structures with intensely bioturbated foresets and remnants of bryozoan reefs in the lower part. The sediment consists out of heterogenous glauconiferous fine-grained quartz sand with a much lower number of fines $(<125 \mu \mathrm{m} 15 \%)$, a larger amount of coarse grains ( $>250 \mu \mathrm{m} 21-33 \%)$ and glauconite (39-49\%) than that of the Borsbeek member. The color ranges from bluish-green to whitish-gray, depending on the amount of carbonate particles originating from the abrasion of the remains of the inhabitants of the bryozoan reefs that are incorporated in the sediment. Locally, the sediment is very fossiliferous, especially in the lower part. The macrofauna is generally small-sized, with bryozoans, serpulids (e.g. Ditrupa), decapod and cirripede crustaceans, bivalves and gastropods, echinoids and brachiopods. Terebratulids are locally abundant in the lower part and can be found both loose in the sediment as well as encased in sandstone. These terebratulids can also be encrusted by bryozoans. The brachiopod Cryptopora nysti is locally abundant. Shell fragments of lingulid brachiopods (Glottidia dumortieri) occur throughout. Trace fossils Macaronichnus segregatis, M. s. degiberti and Scolicia occur abundantly, and allow to ascribe the member to the Cruziana ichnofacies. Yellowish- to orange-colored clayey-limestone concretions and light-colored calcareous sandstone with bryozoans, terebratulids and small-sized mollusks in mold preservation are locally abundant above the basal gravel. The basal gravel generally contains small quartz and flint pebbles, reworked elasmobranch teeth, fish bones and fragments of marine mammal bones, and sometimes also larger sized concretions and bones that are reworked from top of Borsbeek member.

Age/biozonation: middle Tortonian, upper Miocene (this paper). Dinoflagellates indicate $A$. umbraculum Zone of Dybkjær \& Piasecki (2010) and the upper part of the DN8 Zone of de Verteuil \& Norris (1996) (this paper). According to King (2016), and based on De Meuter \& Laga (1970), De Meuter (1974, 1980), King (1983) and Hooyberghs \& Moorkens (2005), the presence of the Foraminifera Elphidium dopperti (E. antoninum), Uvigerina pygmaea and U. venusta (hosiusi) deurnensis, together with the common presence of dextral Neogloboquadrina atlantica ('Globigerina pachyderma') are indicative of Zone NS40 of King (2016). The presence of Bolboforma metzmacheri, indicative of the B. metzmacheri Zone (De Meuter, 1974; Willems, 1976; Spiegler, 2001), allows to refine the latter positioning to King (2016)'s Subzone NS40b and to date it in the interval between 9.54 and $8.8 \mathrm{Ma}$.

Type locality and section: De Meuter \& Laga (1976) only named 'Deurne' and 'temporary exposures of shallow excavations at Deurne' as the type section, while Glibert \& de Heinzelin de Braucourt (1955a) only gave a composite section based on the observations of Mourlon (1876) at four outcrops at Deurne and Borgerhout. Bosselaers et al. (2004) identified VII BR Borgerhout Rivierenhof described by De Meuter et al. (1967, fig. 2, Section A), De Meuter \& Laga (1970, text-fig. 1) and De Meuter et al. (1976, fig. 17) as the most relevant of all the studied sections, and designated it as the stratotype. However, as discussed in the present study, this proposed stratotype presents several shortcomings and the Middelares section of Bosselaers et al. (2004) could become a better stratotype section after being additionally documented for its microfossil content, namely dinoflagellates and Bolboforma. 
Geographical extent: Diest Formation in the Antwerp area (pro parte). Occurrence and correlation outside the Antwerp area needs to be resolved, but possibly correlative to the coarsegrained Diest sand of the Hageland and southern Campine areas.

\section{Acknowledgements}

The authors are extremely grateful to Eddy De Neve of Blaton, Günther Vanden Bossche and Koen Thijs of Jan De Nul n.v. and Werner Nijs and Alain Cox of 'Agentschap Wegen en Verkeer' for granting access to the AIA temporary outcrop, and to Stijn Claeys and Boris Van Dingenen (Waterbouwkundig Laboratorium) for access to a temporary outcrop at Waterbouwkundig Labo.

The authors also are extremely grateful to all those who assisted them in the field and sharing and discussing their finds and thoughts, in particular (in alphabetical order): Luc Anthonis (ERB), Taco Bor (DCG), Geert De Borger (DCG), Pieter De Schutter (DCG, RBINS), Leo Dufraing (RBINS), Ben D'Haeze (ERB), Robert Marquet (DCG, RBINS), Theo Lambrechts (DCG, ERB), Thomas Reinecke (DCG), Jef Segers (DCG, RBINS), Jeroen Van Boeckel (DCG), Walter Van Remoortel (DCG), Gerard Verwey (DCG), Fritz von der Hocht (DCG), Frank Wesselingh (Naturalis) and Eric Wille (ERB). Alfréd Dulai (Hungarian Natural History Museum) helped with the identification of Cryptopora nysti, Robert Marquet (RBINS) with the identification of some of the bivalves, Evgeny Popov (Saratov State University, Russia) with the identification of the chimaeroid mandibular remains collected by the JDC group, and Wim Wouters (RBINS) helped us to compare fossil teleost and bird remains with Recent material in collections under his care. Yves Samyn (RBINS) gave access to the Middelares samples under his care. Jasper Verhaegen (VPO) is thanked for information on heavy minerals, Peter Stassen (KU Leuven \& RBINS) for access to literature.

Marleen De Ceuckelaire (RBINS) and Katrien De Nil (VPO) are thanked for their efforts connecting the outcrops discussed in the text with the database of the Geological Survey of Belgium (GSB) and that of the Databank Ondergrond Vlaanderen (DOV), respectively, they also supplied the links to their descriptions in Table 1.

Elvira Vassilieva and Nancy Weyns are greatly thanked for the help in the laboratory analyses and Herman Nijs to produce high-quality thin sections (all KU Leuven). Sabine Vancauwenberghe (UGent) is kindly tanked for the maceration of the palynological samples.

The authors are grateful to editor Noël Vandenberghe and two additional anonymous reviewers for their constructive comments which helped to improve the quality of this paper.

\section{References}

Adriaens, R., 2015. Neogene and Quaternary clay minerals in the southern North Sea. Aardkundige Mededelingen, 47, 1-272.

Adriaens, R. \& Vandenberghe, N., 2020. Quantitative clay mineralogy as a tool for lithostratigraphy of Neogene Formations in Belgium: a reconnaissance study. Geologica Belgica, 23/3-4, this volume. https://doi.org/10.20341/gb.2020.018

Adriaens, R., Vandenberghe, N. \& Elsen, J., 2014. Natural clay-sized glauconite in the Neogene deposits of the Campine Basin (Belgium). Clays and Clay Minerals, 62, 35-52. https:// doi.org/10.1346/ccmn.2014.0620104

Alfsen, A., Bosselaers, M. \& Lambert, O., in press. New sperm whale remains from the late Miocene of the North Sea and a revised family attribution for the small crown physeteroid Thalassocetus. Comptes Rendus Palevol.

Allen, J.R.L., 1966. On bed forms and palaeocurrents. Sedimentology, 6, 153-190. https://doi.org/10.1111/j.1365-3091.1966.tb01576.x

Asgaard, U. \& Bromley, R.G., 2007. Co-occurrence of Schizasterid echinoids and the trace fossil Scolicia, Pleistocene, Greece: facts, myths, and fascioles. In Bromley, R.G., Buatois, L.A., Mángano, M.G., Genise, J.F. \& Melchor, R.N. (eds), Sediment-Organism Interactions: A Multifaceted Ichnology. SEPM Society for Sedimentary Geology, Tulsa, OK, Special Publications, 88, 87-95. https://doi.org/10.2110/pec.07.88.0087

Bernardi, M., Boschele, S., Ferretti, P. \& Avanzini, M., 2010. Echinoid burrow Bichordites monastiriensis from the Oligocene of NE Italy. Acta Palaeontologica Polonica, 55/3, 479-486. https:// doi.org/10.4202/app.2009.0064

Bisconti, M., 2015. Anatomy of a new cetotheriid genus and species from the Miocene of Herentals, Belgium, and the phylogenetic and palaeobiogeographical relationships of Cetotheriidae ss. (Mammalia, Cetacea, Mysticeti). Journal of Systematic Palaeontology, 13, 377-395. https:// doi.org/10.1080/14772019.2014.890136

Bor, T., Reinecke, T. \& Verschueren, S., 2012. Miocene Chondrichthyans from Winterswijk-Miste, The Netherlands. Palaeontos 21, 1-136.

Bosselaers, M., Herman, J., Hoedemakers, K., Lambert, O., Marquet, R. \& Wouters, K., 2004. Geology and palaeontology of a temporary exposure of the Late Miocene Deurne Sand Member in Antwerpen (N. Belgium). Geologica Belgica, 7/1-2, 27-39.

Bromley, R.G., Milàn, J., Uchman, A. \& Hansen, K.S., 2009. Rheotactic Macaronichnus, and human and cattle trackways in Holocene beachrock, Greece: reconstruction of paleoshoreline orientation. Ichnos, 16, 103-117. https://doi.org/10.1080/10420940802470987

Clifton, H.E. \& Thompson, J.K., 1978. Macaronichnus segregatis: a feeding structure of shallow marine polychaetes. Journal of Sedimentary Research, 48, 1293-1302. https://doi.org/10.2110/ jsr.48.1

Cogels, P., 1874. Seconde note sur le gisement de la Terebratula grandis avec quelques observations à ce sujet. Annales de la Société malacologique de Belgique, Bulletins, 9, 38-45.

Colella, A. \& D'Alessandro, A., 1988. Sand waves, Echinocardium traces and their bathyal depositional setting (Monte Torre Palaeostrait, Plio-Pleistocene, southern Italy). Sedimentology, 35, 219-237. http://dx.doi.org/10.1111/j.1365-3091.1988.tb00946.x

Collareta, A., Merella, M., Mollen F.H., Casati, S. \& Di Cencio, A., 2020. The extinct catshark Pachyscyllium distans (Probst, 1879) (Elasmobranchii: Carcharhiniformes) in the Pliocene of the Mediterranean Sea. Neues Jahrbuch für Geologie und Paläontologie Abhandlungen, 295/2, 129-139. https://dx.doi.org/10.1127/ njgpa/2020/0877

Compagno, L.J.V., 1984. FAO species catalogue. Sharks of the world: An annotated and illustrated catalogue of shark species known to date. FAO Fisheries Synopsis, 125, 1-655.

Dejardin, A.P.C., 1862. Description de deux coupes faites à travers les couches des systèmes scaldisien et diestien, ainsi que les couches supérieures près de la ville d'Anvers. Bulletins de l'Académie royale des Sciences, des Lettres et des Beaux-Arts de Belgique, $2^{\circ}$ série, $13 / 5,441-444$.

Dekkers, J. \& Munsterman, D., 2020. Middle Miocene depositional evolution of the central Roer Valley Rift System. Geological Journal, 55, 6188-6197. https://doi.org/10.1002/gj.3799

De Meuter, F., 1974. Bijdrage tot de systematiek en de paleoecologie van de benthonische foraminiferen uit het Mioceen van België. Unpublished Ph.D. Thesis, Katholieke Universiteit Leuven, Leuven, Part I, 30 p.

De Meuter, F., 1980. Benthonic Foraminifera from the Miocene of Belgium. Aardkundige Mededelingen, 1, 78-169.

De Meuter, F.J.C. \& Laga, P.G.H., 1970. Coiling ratios and other variations of Globigerina pachyderma (Ehrenberg, 1861) and the stratigraphic significance in the Neogene deposits of the Antwerpen area, Belgium. Bulletin de la Société belge de Géologie, de Paléontologie et d'Hydrologie, 79/2, 175-184.

De Meuter, F.J. \& Laga, P.G., 1976. Lithostratigraphy and biostratigraphy based on benthonic foraminifera of the Neogene 
deposits of Northern Belgium. Bulletin de la Société belge de Géologie, 85/4, 133-152.

De Meuter, F.J., Laga, P.G., Ringelé, A. \& Roose, V., 1967. Compte rendu de l'excursion du samedi 29 octobre 1966, faite à Deurne, près d'Anvers. Bulletin de la Société belge de Géologie, de Paléontologie et d'Hydrologie, 75, 392-394.

De Meuter, F., Wouters, K. \& Ringelé, D., 1976. Lithostratigraphy of Miocene sediments from temporary outcrops in the Antwerp city area: Pl. Antwerpen $28 \mathrm{~W}, \mathrm{Pl}$. Borgerhout $28 \mathrm{E}$. Service Géologique de Belgique, Professional Paper, 1976/3, 19 p.

de Verteuil, L. \& Norris, G., 1996. Miocene dinoflagellate stratigraphy and systematics of Maryland and Virginia. Micropaleontology, 42, Supplement, 1-172. https://doi.org/10.2307/1485926

Dewaele, L., Amson, E., Lambert, O. \& Louwye, S., 2017a. Reappraisal of the extinct seal "Phoca" vitulinoides from the Neogene of the North Sea Basin, with bearing on its geological age, phylogenetic affinities, and locomotion. PeerJ, 5:e3316. https://doi.org/10.7717/ peerj. 3316

Dewaele, L., Lambert, O. \& Louwye, S., 2017b. On Prophoca and Leptophoca (Pinnipedia, Phocidae) from the Miocene of the North Atlantic realm: redescription, phylogenetic affinities and paleobiogeographic implications. PeerJ, 5:e3024. https:// doi.org/10.7717/peerj.3024

Dewaele, L., Lambert, O., Louwye, S., 2018. A critical revision of the fossil record, stratigraphy and diversity of the Neogene seal genus Monotherium (Carnivora, Phocidae). Royal Society open science, 5, 171669. https://dx.doi.org/10.1098\%2Frsos. 171669

Dulai, A., 2013. Sporadic Miocene brachiopods in the Naturalis Biodiversity Center (Leiden, the Netherlands): Records from the Mediterranean, the North Sea, and the Atlantic Ocean. Fragmenta Palaeontologica Hungarica, 30, 15-51.

Dybkjær, K. \& Piasecki, S., 2010. Neogene dinocyst zonation for the eastern North Sea Basin, Denmark. Review of Palaeobotany and Palynology, 161/1-2, 1-29. https://doi.org/10.1016/ j.revpalbo.2010.02.005

Ekdale, A.A., 1992. Muckraking and mudslinging: the joys of depositfeeding. In Maples, C.G. \& West, R.R. (eds), Trace fossils. The Paleontological Society, Tulsa, Short Courses in Paleontology, 5, 145-171. https://doi.org/10.1017/S2475263000002336

Everaert, S., De Schutter, P., Mariën, G., Cleemput, G., Van Boeckel, J., Rondelez, D. \& Bor., T., 2019. Een vroeg-miocene fauna uit het Zand van Kiel (Formatie van Berchem) bij Post $\mathrm{X}$ in Berchem (Antwerpen). Afzettingen (Werkgroep voor Tertiaire en Kwartaire Geologie), 40/4, 83-98.

Frey, R.W. \& Pemberton, S.G., 1991. The ichnogenus Schaubcylindrichnus: morphological, temporal, and environmental significance. Geological Magazine, 128, 595-602. https:// doi.org/10.1017/S0016756800019713

Frey, R.W., Howard, J.D. \& Pryor, W.A., 1978. Ophiomorpha: its morphologic, taxonomic, and environmental significance. Palaeogeography, Palaeoclimatology, Palaeoecology, 23, 199-223. https://doi.org/10.1016/0031-0182(78)90094-9

Frey, R.W., Curran, A.H. \& Pemberton, G.S., 1984. Trace making activities of crabs and their environmental significance: the ichnogenus Psilonichnus. Journal of Paleontology, 58, 333-350.

Geets, S. \& De Breuck, W., 1991. De zware-mineraleninhoud van Belgische Mesozoïsche en Cenozoïsche afzettingen - Neogeen. Natuurwetenschappelijk Tijdschrift, 73, 3-37.

Glibert, M. \& de Heinzelin de Braucourt, J., 1955a. La faune et l'âge Miocène supérieur des Sables de Deurne : I. Descriptions. Bulletin de l'Institut royal des Sciences naturelles de Belgique, 30/71, 1-27.

Glibert, M. \& de Heinzelin de Braucourt, J., 1955b. La faune et l'âge Miocène supérieur des Sables de Deurne : II. Conclusions. Bulletin de l'Institut royal des Sciences naturelles de Belgique, 31/72, 1-12.

Gulinck, M. \& Laga, P., 1975. Lithological description and foraminifera investigation of the Oostmalle - Rijkevorsel 16e153 borehole. Unpublished notes of P. Laga. Archives Geological Survey of Belgium, Brussels, Belgium.
Hammerschlag, N., Williams, L., Fallows, M. \& Fallows, C., 2019. Disappearance of white sharks leads to the novel emergence of an allopatric apex predator, the sevengill shark. Scientific Reports, 9/1908. https://doi.org/10.1038/s41598-018-37576-6

Heithaus, M.R., 2001. The biology of tiger sharks, Galeocerdo cuvier, in Shark Bay, Western Australia: sex ratio, size distribution, diet, and seasonal changes in catch rates. Environmental biology of fishes, 61, 25-36. https://doi.org/10.1023/A:1011021210685

Hoedemakers, K. \& Dufraing, L., 2015. Elasmobranchii in de ontsluiting aan de luchthaven te Borsbeek (prov. Antwerpen, België). Afzettingen WTKG, 36/1, 12-19.

Hoedemakers, K. \& Dufraing, L., 2018. Een profiel bij Posthofbrug (Antwerpen). Afzettingen WTKG, 39/2, 65-80.

Hooyberghs, H.J.F. \& Moorkens, T.L.A., 2005. Biostratigraphic study of the "Middelares Hospital" outcrop section in the Deurne Sand Member (Upper Miocene, Belgium) as based on foraminifera. Neues Jahrbuch für Geologie und Paläontologie, Abhandlungen, 237/1, 5-28. https://doi.org/10.1127/njgpa/237/2005/5

Houthuys, R., 2014. A reinterpretation of the Neogene emersion of central Belgium based on the sedimentary environment of the Diest Formation and the origin of the drainage pattern. Geologica Belgica, 17, 211-235.

Houthuys, R., Adriaens, R., Goolaerts, S., Laga, P., Louwye, S., Matthijs, J., Vandenberghe, N. \& Verhaegen, J., 2020. The Diest Formation: a review of insights from the last decades. Geologica Belgica, 23/3-4, this volume. https://doi.org/10.20341/gb.2020.012

Keighley, D.G. \& Pickerill, R., 1994. The ichnogenus Beaconites and its distinction from Ancorichnus and Taenidium. Palaeontology, 37, 305-337.

Keighley, D.G. \& Pickerill, R.K., 1995. The ichnotaxa Palaeophycus and Planolites: historical perspectives and recommendations. Ichnos, 3, 301-309. https://doi.org/10.1080/10420949509386400

King, C., 1983. Cainozoic Micropalaeontological Biostratigraphy of the North Sea. Report of the Institute of Geological Sciences, 82/7, $40 \mathrm{p}$.

King, C., 2016. A revised correlation of Tertiary rocks in the British Isles and adjacent areas of NW Europe. Gale, A.S. \& Barry, T.L. (eds). Geological Society, London, Special Reports, 27, 1-719. https://doi.org/10.1144/SR27

Knaust, D., 2017. Atlas of Trace Fossils in Well Core: Appearance, Taxonomy and Interpretation. Springer, Cham, 209 p. https:// doi.org/10.1007/978-3-319-49837-9

Laga, P. \& De Meuter, F., 1972. A foraminiferal fauna found in the lower Member of the Diest Formation of borings in the Antwerp Kempen (NE-Belgium). Bulletin de la Société belge de Géologie, de Paléontologie et d'Hydrologie, 81, 211-220.

Lambert, O., 2005a. Phylogenetic affinities of the long-snouted dolphin Eurhinodelphis (Cetacea, Odontoceti) from the Miocene of Antwerp. Palaeontology, 48/3, 653-679. https://doi.org/10.1111/ j.1475-4983.2005.00472.x

Lambert, O., 2005b. Systematics and phylogeny of the fossil beaked whales Ziphirostrum du Bus, 1868 and Choneziphius Duvernoy, 1851 (Cetacea, Odontoceti), from the Neogene of Antwerp (North of Belgium). Geodiversitas, 27, 443-497.

Louwye, S., 2002. Dinoflagellate cyst biostratigraphy of the Upper Miocene Deurne Sands (Diest Formation) of northern Belgium, southern North Sea Basin. Geological Journal, 37/1, 55-67. https:// doi.org/10.1002/gj. 900

Louwye, S. \& Laga, P., 2008. Dinoflagellate cyst stratigraphy and palaeoenvironment of the marginal marine Middle and Upper Miocene of the eastern Campine area, northern Belgium (southern North Sea Basin). Geological Journal, 43, 75-94. https:// doi.org/10.1002/gj.1103

Louwye, S., De Coninck, J. \& Verniers, J., 1999. Dinoflagellate cyst stratigraphy and depositional history of Miocene and Lower Pliocene formations in northern Belgium (southern North Sea Basin). Geologie en Mijnbouw, 78, 31-46. https://doi.org/10.1023/ A:1003793300214 
Louwye, S., Head, M. \& De Schepper, S., 2004. Dinoflagellate cyst stratigraphy and palaeoecology of the Pliocene in northern Belgium, southern North Sea Basin. Geological Magazine, 141/3, 353-378. https://doi.org/10.1017/S0016756804009136

Louwye, S., De Schepper, S., Laga, P. \& Vandenberghe, N., 2007. The Upper Miocene of the southern North Sea Basin (northern Belgium): a palaeoenvironmental and stratigraphical reconstruction using dinoflagellate cysts. Geological Magazine, 144, 33-52. https://doi.org/10.1017/S0016756806002627

Louwye, S., Marquet, R., Bosselaers, M. \& Lambert, O., 2010. Stratigraphy of an early-middle Miocene sequence near Antwerp in northern Belgium (southern North Sea Basin). Geologica Belgica, $13 / 3,269-284$.

Louwye, S., Deckers, J., Verhaegen, J., Adriaens, R. \& Vandenberghe, N., 2020. A review of the lower and middle Miocene of northern Belgium. Geologica Belgica, 23/3-4, this volume. https:// doi.org/10.20341/gb.2020.010

Lowe, C.G., Wetherbee, B.M., Crow, G.L. \& Tester, A.L., 1996. Ontogenetic dietary shifts and feeding behavior of the tiger shark, Galeocerdo cuvier, in Hawaiian waters. Environmental Biology of Fishes, 47, 203-211. https://doi.org/10.1007/BF00005044

Löwemark, L. \& Nara, M., 2010. Morphology, ethology and taxonomy of the ichnogenus Schaubcylindrichnus: Notes for clarification. Palaeogeography, Palaeoclimatology, Palaeoecology, 297, 184187. https://doi.org/10.1016/j.palaeo.2010.07.028

MacEachern, J.A., Bann, K.L., Gingras, M.K., Zonneveld, J.-P., Dashtgard, S.E. \& Pemberton, S.G., 2012. The ichnofacies paradigm. In Knaust, D. \& Bromley, R.G. (eds), Trace Fossils as Indicators of Sedimentary Environments. Elsevier, Amsterdam, Developments in Sedimentology, 64, 103-138. https:// doi.org/10.1016/B978-0-444-53813-0.00004-6

Marquet, R. \& Herman, J., 2009. The stratigraphy of the Pliocene of Belgium. Palaeofocus, 2, 1-39.

Misonne, X., 1958. Faune du Tertiaire et du Pléistocène inférieur de Belgique (Oiseaux et Mammifères). Bulletin de l'Institut royal des Sciences naturelles de Belgique, 34, 1-36.

Mollen, F.H., 2010. A partial rostrum of the porbeagle shark Lamna nasus (Lamniformes, Lamnidae) from the Miocene of the North Sea Basin and the taxonomic importance of rostral morphology in extinct sharks. Geologica Belgica, 13/1-2, 61-76.

Mourlon, M., 1876. Sur les dépôts qui, aux environs d'Anvers, séparent les sables noirs miocènes des couches pliocènes scaldisiennes. Bulletin de l'Académie royale des Sciences, des Lettres et des Beaux-Arts de Belgique, $2^{\mathrm{e}}$ série, 42, 760-790.

Musick, J.A. \& Ellis, J.K., 2005. Reproductive evolution of Chondrichthyans. In Hamlett, W.C. (ed.), Reproductive Biology and Phylogeny of Chondrichthyes: Sharks, Batoids and Chimaeras. Science Publishers, Enfield (NH), Reproductive Biology and Phylogeny, 3, 45-79.

Nara, M. \& Seike, K., 2019. Palaeoecology of Macaronichnus segregatis degiberti: Reconstructing the infaunal lives of the travisiid polychaetes. Palaeogeography, Palaeoclimatology, Palaeoecology, 516, 284-294. https://doi.org/10.1016/j.palaeo.2018.12.011

Neto de Carvalho, C., Viegas, P.A. \& Cachão, M., 2007. Thalassinoides and its producer: populations of Mecochirus buried within their burrow systems, Boca do Chapim Formation (Lower Cretaceous), Portugal. Palaios, 22, 104-109. https://doi.org/10.2110/ palo.2006.p06-011r

Pemberton, S.G. \& Frey, R.W., 1982. Trace fossil nomenclature and the Planolites-Palaeophycus dilemma. Journal of Paleontology, 56, 843-881.

Pemberton, S.G., Spila, M., Pulham, A.J., Saunders, T., MacEachern, J.A., Robbins, D. \& Sinclair, I.K., 2001. Ichnology and sedimentology of shallow to marginal marine systems: Ben Nevis and Avalon Reservoirs, Jeanne D'Arc Basin. Geological Association of Canada, Short Course Notes, 1, 343.

Pollard, J.E., Goldring R. \& Buck, S.G., 1993. Ichnofabrics containing Ophiomorpha: significance in shallow-water facies interpretation.
Journal of the Geological Society of London, 150, 149-164. https:// doi.org/10.1144/gsjgs.150.1.0149

Post, K., Louwye, S. \& Lambert, O., 2017. Scaldiporia vandokkumi, a new pontoporiid (Mammalia, Cetacea, Odontoceti) from the Late Miocene to earliest Pliocene of the Westerschelde estuary (The Netherlands). PeerJ, 5, e3991. https://doi.org/10.7717/peerj.3991

Pretorius, C. \& Griffiths, C.L., 2013. Patterns of egg deposition and egg development in the catsharks Poroderma pantherinum and Haploblepharus pictus. African zoology, 48/1, 115-124. http:// dx.doi.org/10.3377/004.048.0114

Radwańska, U. \& Radwański, A., 2003. Bosquet's (1862) inarticulate brachiopods: Discinisca elslooensis sp. n. from the Elsloo Conglomerate. Bulletin de l'Institut royal des Sciences naturelles de Belgique, Sciences de la Terre, 73, 185-194.

Reinecke, T., von der Hocht, F. \& Dufraing, L., 2015. Fossil basking sharks of the genus Keasius (Lamniformes, Cetorhinidae) from the boreal North Sea Basin and Upper Rhine Graben: evolution of dental characteristics from the Oligocene to late Middle Miocene and description of two new species. Palaeontos, 28, 39-98.

Ringelé, A., 1974. Bijdrage tot de systematiek, de evolutie en de paleoecologie van Bivalvia uit Neogene afzettingen van NoordBelgië. Unpublished Ph.D. Thesis, Katholieke Universiteit Leuven, Leuven, $280 \mathrm{p}$.

Rodríguez-Tovar, F.J. \& Aguirre, F., 2014. Is Macaronichnus an exclusively small, horizontal and unbranched structure? Macaronichnus segregatis degiberti isubsp. nov. Spanish Journal of Palaeontolology, 29, 131-142. http://doi.org/10.7203/sjp.29.2.17682

Seike, K., Yanagishima, S., Nara, M. \& Sasaki, T., 2011. Large Macaronichnus in modern shoreface sediments: Identification of the producer, the mode of formation, and paleoenvironmental implications. Palaeogeography, Palaeoclimatology, Palaeoecology, 311, 224-229. https://doi.org/10.1016/j.palaeo.2011.08.023

Spiegler, D., 2001. Bolboforma biostratigraphy in the Neogene glauconitic sands of Belgium. In Vandenberghe, N. (ed.), Contributions to the Paleogene and Neogene stratigraphy of the North Sea Basin. Aardkundige Mededelingen, 11, 61-68.

Steeman, M.E., 2010. The extinct baleen whale fauna from the MiocenePliocene of Belgium and the diagnostic cetacean ear bones. Journal of Systematic Palaeontology, 8/1, 63-80. https:// doi.org/10.1080/14772011003594961

Uchman, A., 1995. Taxonomy and palaeoecology of flysch trace fossils: The Marnoso-arenacea Formation and associated facies (Miocene, Northern Apennines, Italy). Beringeria, 15, 3-115.

Uchman, A., Johnson, M.E., Ramalho, R., Quartau, R., Berning, B., Hipólito, A., Melo, C., Rebelo, A.C., Cordeiro, R. \& Ávila, S.P., 2020. Neogene marine sediments and biota encapsulated between lava flows on Santa Maria Island (Azores, north-east Atlantic): An interplay between sedimentary, erosional, and volcanic processes. Sedimentology, 67, 3595-3618. https://doi.org/10.1111/sed.12763

Van Beneden, P.-J., 1885. Description des ossements fossiles des environs d'Anvers. Quatrième partie. Cétacés. Genre Plesiocetus. Annales du Musée royal d'Histoire naturelle de Belgique, 9, 1-40.

Van Beneden, P.-J., 1886. Description des ossements fossiles des environs d'Anvers. Cinquième partie. Cétacés. Genres Amphicetus, Heterocetus, Mesocetus, Idiocetus et Isocetus. Annales du Musée royal d'Histoire naturelle de Belgique, 13, 1-139.

Vandenberghe, N., Laga, P., Louwye, S., Vanhoorne, R., Marquet, R., De Meuter, F., Wouters, K. \& Hagemann, H.W., 2005. Stratigraphic interpretation of the Neogene marine - continental record in the Maaseik well (49W0220) in the Roer Valley Graben, NE Belgium. Memoirs of the Geological Survey of Belgium, 52, $39 \mathrm{p}$.

Vandenberghe, N., Harris, W.B., Wampler, J.M., Houthuys, R., Louwye, S., Adriaens, R., Vos, K., Lanckacker, T., Matthijs, J., Deckers, J., Verhaegen, J., Laga, P., Westerhoff, W. \& Munsterman, D., 2014. The implications of K/Ar glauconite dating of the Diest Formation on the paleogeography of the Upper Miocene in Belgium. Geologica Belgica, 17/2, 161-174. 
van den Bosch, M., 1967a. Het Deurnien van Borgerhout en enkele opmerkingen over de stratigrafie van het mioceen in het Noordzeebekken. Mededelingen van de Werkgroep voor Tertiaire en Kwartaire Geologie, 4/2, 45-48.

van den Bosch, M., 1967b. Deurnien ontsloten in Antwerpen Borgerhout. Mededelingen van de Werkgroep voor Tertiaire en Kwartaire Geologie, 4/2, 35-37.

van den Bosch, M., 1967c. Nogmaals het Deurnien van Borgerhout. Mededelingen van de Werkgroep voor Tertiaire en Kwartaire Geologie, 4/3, 62-63.

Van den Broeck, E., 1878. Esquisse géologique et paléontologique des dépôts pliocènes des environs d'Anvers. G. Mayolez, Bruxelles, 9-293.

Van Herck, M., 2019. Stratigrafische studie van de grens tussen het Antwerpen lid (Berchem formatie) en bovenliggende lid van Deurne (basis van de Diest formatie). Unpublished Bachelor Project Report, Katholieke Universiteit Leuven (Geologie), Leuven, 52 p.

Van Straelen, V., 1920. Observations sur le Diestien et le Quaternaire à Deurne-Sud, près Anvers. Bulletin de la Société belge de Géologie, de Paléontologie et d'Hydrologie, 30/1, 123-127.

Verhaegen, J., 2019. Quantitative sediment provenance and volumetric reconstruction: application to the Miocene of the Southern North Sea Basin. Unpublished Ph.D. Thesis, KU Leuven, Leuven, 239 p.

Verhaegen, J., 2020. Stratigraphic discriminatory potential of heavy mineral analysis for the Neogene sediments of Belgium. Geologica Belgica, 23/3-4, this volume. https://doi.org/10.20341/gb.2020.003

Verhaegen, J., Weltje, G.J. \& Munsterman, D., 2019. Workflow for analysis of compositional data in sedimentary petrology: provenance changes in sedimentary basins from spatio-temporal variation in heavy-mineral assemblages. Geological Magazine, 156/7, 1111-1130. https://doi.org/10.1017/S0016756818000584

Wesselingh, F.P., Busschers, F.S. \& Goolaerts, S., 2020. Observations on the Pliocene sediments exposed at Antwerp International Airport (northern Belgium) constrain the stratigraphic position of the Broechem fauna. Geologica Belgica, 23/3-4, this volume. https:// doi.org/10.20341/gb.2020.026

Wienrich, G., 2009. Die Fauna des marinen Miozäns von Kevelaer (Niederrhein). Band 5: Vertebraten. Backhuys Publishers, Leiden and Margraf Publishers, Weikersheim, 955-1229.

Willems, W., 1976. The genus Bolboforma Von Daniels \& Spiegler in the Upper Miocene of northern Belgium. Bulletin de la Société belge de Géologie, 85/1, 31-38.

Williams, G.L., Fensome, R.A. \& MacRae, R.A., 2017. The Lentin and Williams index of fossil dinoflagellates 2017 edition. American Association of Stratigraphic Palynologists Contributions Series, 48, $1-1097$.

Witzell, W.N., 1987. Selective predation on large cheloniid sea turtles by tiger sharks (Galeocerdo cuvier). Japanese Journal of Herpetology, 12/1, 22-29. https://doi.org/10.5358/hsj1972.12.1_22

Wood, S.V., 1872. Supplement to the Crag Mollusca, comprising Testacea from the Upper Tertiaries of the East of England. Part I: Univalves. Monograph of the Palaeontographical Society London, $25,1-98$.

Manuscript received 30.08.2020, accepted in revised form 13.11.2020, available online 21.12.2020.

Supplementary materials are available online at https:// doi.org/10.20341/gb.2020.011 